Portland State University

PDXScholar

\title{
Democratic Ideology, the Frontier Ethos, Medical Practice and Hospital Culture: Pacific Northwest Health-Seekers, Community Health and the Sisters of Providence, Vancouver, WA 1856 - 1879
}

\author{
Susan T.L. Courtney \\ Portland State University
}

Follow this and additional works at: https://pdxscholar.library.pdx.edu/open_access_etds

Part of the History of Science, Technology, and Medicine Commons, Public History Commons, and the United States History Commons

Let us know how access to this document benefits you.

\section{Recommended Citation}

Courtney, Susan T.L., "Democratic Ideology, the Frontier Ethos, Medical Practice and Hospital Culture:

Pacific Northwest Health-Seekers, Community Health and the Sisters of Providence, Vancouver, WA 1856 - 1879" (1992). Dissertations and Theses. Paper 5632.

https://doi.org/10.15760/etd.7504

This Thesis is brought to you for free and open access. It has been accepted for inclusion in Dissertations and Theses by an authorized administrator of PDXScholar. Please contact us if we can make this document more accessible: pdxscholar@pdx.edu. 
AN ABSTRACT OP THE THESIS OP Susan T.L. Courtney for the Masters of Arts in History presented October 30, 1992.

Title: Democratic Ideology, the Frontier Ethos, Medical Practice and Hospital Culture: Pacific Northwest Health-Seekers, Community Health and the Sisters of Providence, Vancouver, WA 1856 - 1879. APPROVED BY THE MEMBERS OF THE THESIS COMMITTEE:

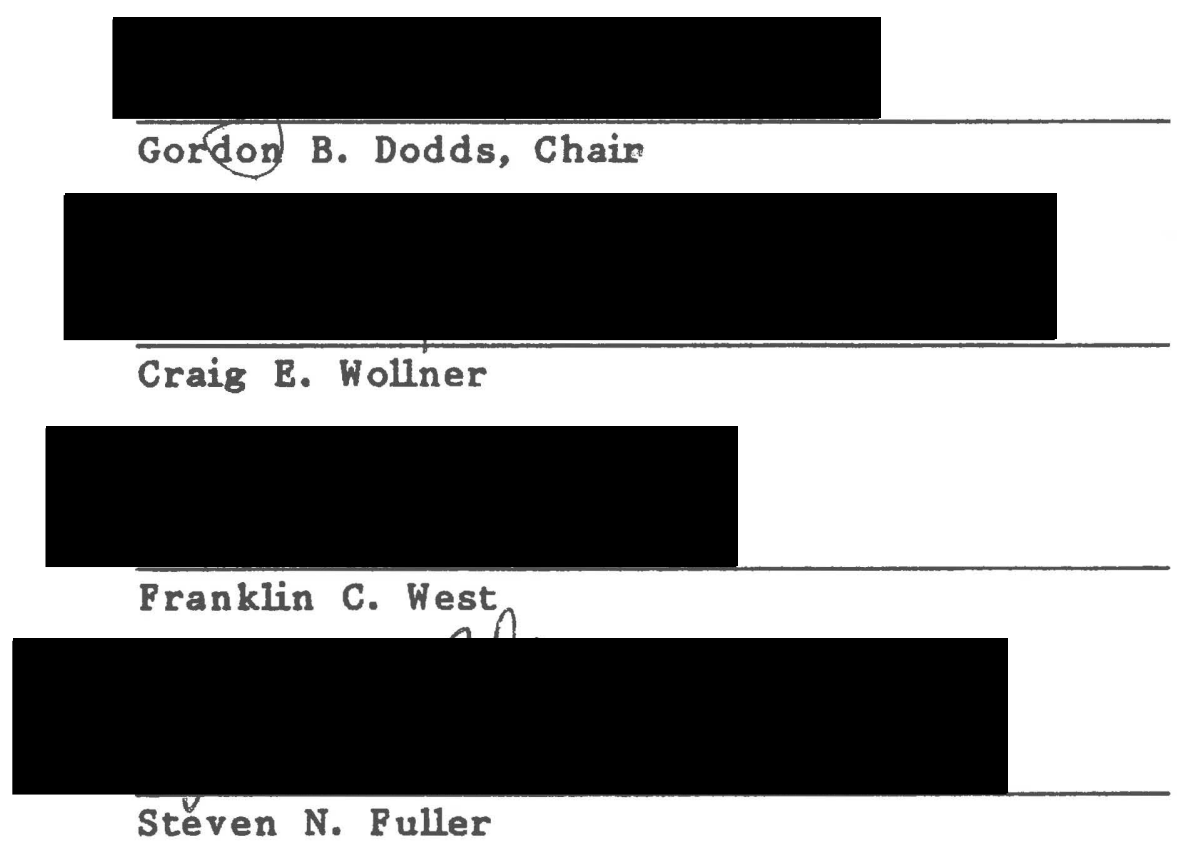

Most historians readily acknowledge the economic incentive that prompted many pioneers to migrate westward across the overland trail. Health motivations remain generally unexplored. Many Americans had settled the interior regions most suited to farming, especially the acreage around river valleys in the Mississippi drainage system. Unfortunately, health conditions were not favorable to human existence. 
The dilemma of economic well-being versus health disaster motivated a number of Americans to seek better living conditions. Some chose overland migration to the Pacific Northwest.

The situation in contemporary medical practice was a kaleidoscope of competing sects and contradictory convictions. The mainline profession of medicine, failed to meet the needs of patients, was viewed as extreme in nature, and provided justification for the competition that opposed it. Faced with a number of medical options, all of which broke down in the face of epidemic disease, Americans searched for better solutions to medical problems.

Assessing the success of health-seekers is a difficult undertaking. One must address both the population as a demographic group, and its individual beliefs about its new environment. The former depends upon generalized statistics from an inherently biased source, since the ability to correctly identify specific diseases was beyond contemporary technology. On the other hand, observations of settlers were often self-fulfilling prophesies that justified their migration; they reflected only romanticized notions of the promised land. Thus, the story is not easily found in either "hard facts" or anecdotal remembrances.

The community in the Pacific Northwest possessed certain characteristics, both demographically and philosophically, that influenced its development. The population in the $1860 \mathrm{~s}$ and $1870 \mathrm{~s}$ was mostly male and largely youthful. Oregon's mortality rates in the 1860s and 1870 s compared favorably with the national averages. With the exception of females of childbearing ages, age group mortality rates 
were generally below that of the nation. Many aspects of the new environment, including settlement patterns and the age structure of the population, accounted for the lower-than-average death rates. However, the settlers were still left with basic conditions that often worked against them. Many perceived they had found through relocation, health conditions that were vastly superior to those they had abandoned. On the other hand, as communities developed, they were faced with the same problem other more densely populated regions confronted; namely the outbreak of epidemic disease.

The Sisters of Charity of Providence came to the Pacific Northwest in 1856 and immediately established institutions that answered the needs of the community. The community service work, especially among the poor and sick, paved the way for the establishment of St. Joseph Hospital in 1858. At St. Joseph Hospital, philosophical and procedural changes were implemented that initiated a change from the almshouse mentality toward the establishment of professional health care. The role of community service the sisters pursued, in no small way, promoted the development and expansion of their hospital. The patient base in general reflected the demographics of the region. Adult males made up the majority of patients treated at the hospital. The mission itself supplied a younger population of patients who were predominately female.

Pioneers' observations and remembrances were gathered from a variety of sources. Some of the anecdotal information was found in published sources. Other information was gathered from letters, manuscript collections, and census documents. Demographic material was 
compiled from the published volumes of the U.S. Census Bureau. The material on nineteenth century medical and health technologies was gathered from both secondary and primary sources, the latter including a number of books published in the nineteenth century.

Information about the St. James Mission and St. Joseph Hospital, for the most part was provided by the Sisters of Providence Archives, Seattle, Washington. The manuscript collection included chronicles for both the House of Providence and St. Joseph Hospital. In addition, information from the original patient register was utilized to populate a data base from which statistics for the hospital were compiled. Statistics for the mission was compiled from the chronicles for the House of Providence. 
DEMOCRATIC IDEOLOGY, THE FRONTIER ETHOS, MEDICAL PRACTICE AND HOSPITAL CULTURE:

PACIFIC NORTHWEST HEALTH-SEEKERS, COMMUNITY HEALTH AND THE SISTERS OF PROVIDENCE, VANCOUVER, WA 1856 - 1879

\title{
by
}

SUSAN T.L. COURTNEY

A thesis submitted in partial fulfillment of the requirements for the degree of

\author{
MASTER OF ARTS \\ in \\ HIS TORY
}

Portland State University

1992 
TO THE OFPICE OF GRADUATE STUDIES:

The members of the Committe approve the thesis of Susan T.L. Courtney presented October 30, 1992.

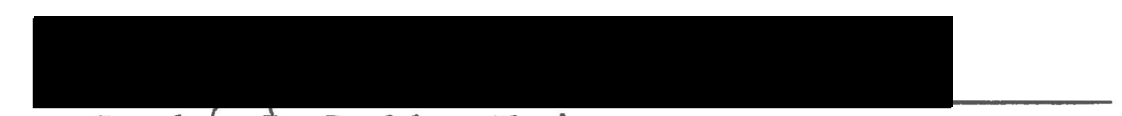

Gordon B. Dodds, Chair

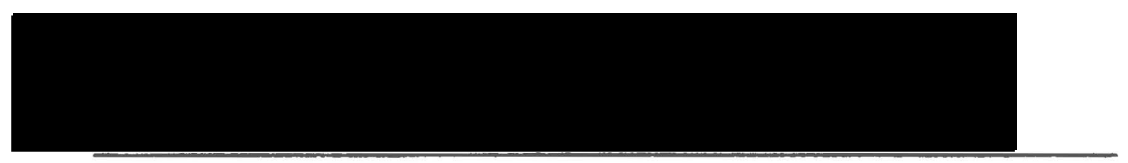

Craig E. Wollner

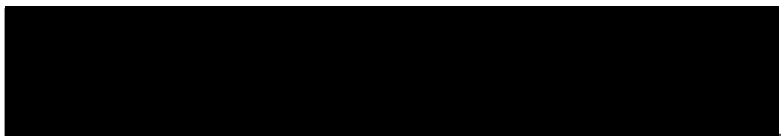

Franklin C. West

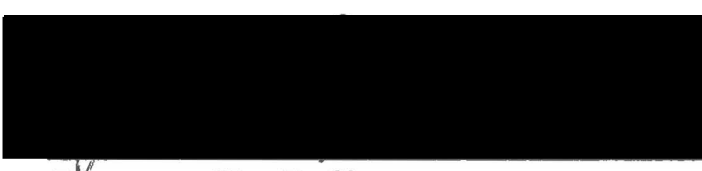

Steven N. Puller

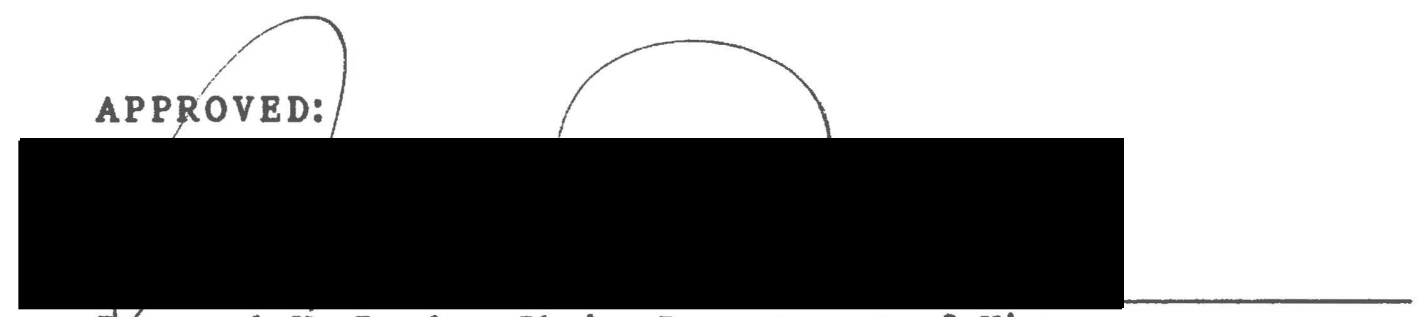

Bernard V. Burke, Chair, Department of History

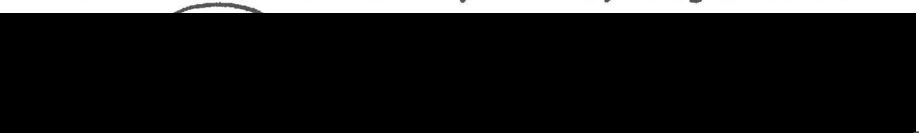

Roy W. Kofh, Vice Provost for Graduate Studies and Research 


\section{ACKNOWLEDGMNTS}

No one works in a vacuum and $m y$ efforts are no exception. Family, friends and strangers have contributed to my work and my thanks seems like an inadequate recognition of the support I have received. For the last three years, Ned Higginbotham has provided the moral and financial support which has made my life worth living and this work possible. I could not have done it without him. Additionally, I would like to recognize George Vaternick of Portland Community College who showed me his unique historical viewpoint and encouraged me to find one of my own.

My interest in migration motivated by health concerns was prompted by an Oregon history seminar course. Professor David Johnson encouraged me to pursue the topic and was instrumental in launching my thesis research. In hind sight, it is clear that I was biased by contemporary culture because I naturally associated hospitals with health care. When I pursued information about the early institutions in the Pacific Northwest, I had little success finding primary source until Barbara Frederiksen introduced me to the Sisters of Providence Archives in Seattle. I felt as if I had struck pay dirt. Not only did the archives contain valuable research material, but the archivists, Sr. Rita Bergamini and Loretta Zwolak Greene, were helpful in many ways, both professionally and personally. I owe them both a debt of gratitude. 
I would also like to acknowledge librarian Heather Rosenwinkel of OHSU who acquainted me with the rare books collection and the "History of Medicine Club" papers hidden in the dark recesses of that institution's library. Additionally, The Inter-Library Loan staff at PSU deserve recognition for their diligent efforts in securing other hard to come by volumes. Professors Gordon Dodds and Craig Wollner guided my thesis, chapter by chapter, and offered valuable criticism even though I often kept them guessing about the final product. My friend Mary Jensen provided careful proof-reading, for only the cost of a lunch. Additionally my parents, F.W. and Helen Courtney, provided encouragement, useful suggestions about books and resources, and listened to the woes of same-day research commutes between Portland and Seattle. While there are many others I have failed to mention here, their contribution was no less valuable and will long be remembered by the author. 
TABLE OF CONTENTS

PAGE

ACKNOWLEDGMENTS

. iii

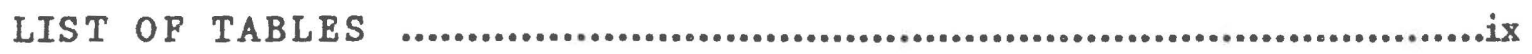

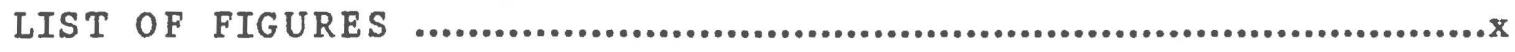

\section{CHAPTER}

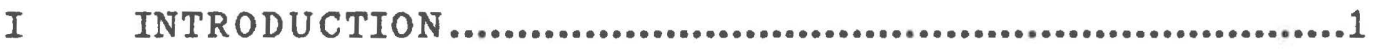

II MIGRATION MOTIVATION............................................5

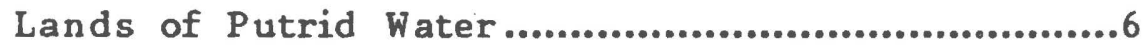

How to Find a Healthy Home Site..........................11

The Chief Culprit ...............................................12

Shattered Appearance ...................................15

Sickly Season ................................................16

Seasoning .....................................................17

Blame the Victim........................................18

III ST. JAMES MISSION $\ldots \ldots \ldots \ldots \ldots \ldots \ldots \ldots \ldots \ldots \ldots \ldots \ldots \ldots \ldots \ldots \ldots \ldots \ldots \ldots \ldots$

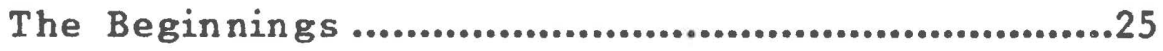

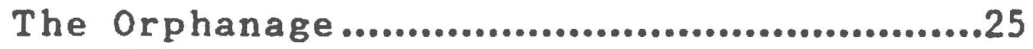

The School......................................................28

Care of the Elderly......................................32

Health Care...............................................................36

Home Visits .................................................36

The Founding of St. Joseph Hospital.............38

Patients and Hospital Growth .........................39

Care of the Insane........................................41

Financing the Operations....................................45 
Orthodox Medicine 51

Education of Regular Physicians ...................51 Therapies of Regular Physicians -- Heroic Medicine.....................................................53

Alternative Therapies..............................................59

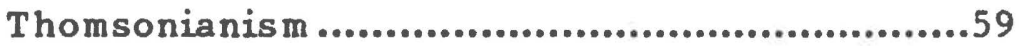

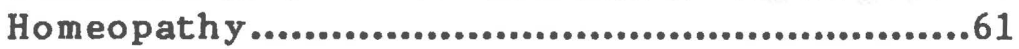

Eclecticis m .................................................63

Other Options ...........................................64

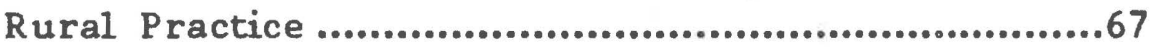

Establishing a Practice ...............................67

Com petition ...................................................68

Hos pitals ............................................................69

The Hospital as an Institution.......................69

Catholic Hospitals .......................................72

V HEALTH FORMULAS ..................................................75

Promotional Literature ...........................................76

Wresting Control Away from the Doctors.......77

Source of Disease......................................78

The Road to Health ............................................79

Exercise .......................................................80

Cleanliness.....................................................81

Pood and Diet..............................................81

Rest, Recreation and Travel ..........................83

Mental Health.............................................85

Cultural Commentary

"Right Living"...............................................85

The Female Gender........................................86

Backlash ..................................................88 
VI DEMOGRAPHIC ASPECTS OF THE PACIFIC NORTHWEST....92

U.S. Population Trends in the Nineteenth

Century ...........................................................992

Oregon's Population Characteristics .....................994

Compared with Other Populations.................94 94

Youthful Age Structure ..............................100

Death Rates ......................................................103

The United States in the Twentieth

Century ......................................................103

Oregon's Mortality Statistics ........................106

Mortality by Age Groups In $1860 \ldots \ldots \ldots \ldots \ldots \ldots . . . .107$

Mortality by Age Groups in $1870 \ldots \ldots \ldots \ldots \ldots . . .109$

VII ST. JOSEPH HOSPITAL...........................................113

Goals, Obstacles, and Observations .....................113

Missionary Role ..........................................113

Underlying Tensions ...................................115

Patients and Patience ..................................117

Good Deaths....................................................118

Shortage of Patients..................................118

The Road to Professionalization..............................120

Establishment of a Pharmacy........................122

Some New Attitudes.......................................123

Expanded Diagnostic Information....................123

Death Rates ....................................................126

Conversions ................................................128

Characteristics of the Patient Population ................130

Sex and Age Profiles of Patients ..................130

Length of Stay.............................................133

Homegrown Patient Base ............................134

Professions .............................................135 
viii

VIII PERSPECTIVES, RECOLLECTIONS, AND REMEMBRANCES....139

Population per Square Mile ................................139

Resident Observations and Opinion ........................141

Some Mixed Reviews .....................................141

The Trials of the Overland Trail....................143

Medical Opinion, Professional and Otherwise ...........144

Observations from Community Members..........144

Disease Reports and the Community...............146

Local Observations .............................................148

IX CONCLUSION...............................................................151

REFERENCES.........................................................................154 


\section{LIST OF TABLES}

TABLE

PAGE

I Twentieth Century Death Rates...........................................104

II Number of Reporting Districts by Age where Crude Female

Death Rates exceeded Crude Male Death Rates................109

III Population per Square Mile of Selected Regions.................140 


\section{LIST OF PIGURES}

FIGURE

PAGE

1. Orphans of the House of Providence...................................27

2. Day Pupils at Providence Academy

3. Boarding Pupils at Providence Academy.............................31

4. Aged Guests of the House of Providence............................33

5. St. James Mission...........................................................34

6. Key to St. James Mission Map.............................................35

7. Home Visits to the Sick..................................................37

8. U.S. Male Population in 1860 by Age..................................93

9. U.S. Female Population in 1860 by Age.............................93

10. Oregon Female Population in 1860 by Age..........................94

11. Oregon Male Population in 1860 by Age............................95

12. Colorado Female Population in 1860 by Age......................96

13. Colorado Male Population in 1860 by Age.........................97

14. Kansas Male Population in 1860 by Age..............................98

15. Kansas Female Population in 1860 by Age.........................98

16. Nebraska Female Population in 1860 by Age.........................99

17. Nebraska Male Population in 1860 by Age..........................100

18. Nale Population Percentages in 1860 by Age.....................102

19. Male Population Percentages in 1870 by Age.....................102

20. Female Population Percentages in 1860 by Age...................103

21. Female Population Percentages in 1870 by Age..................103 
22. 1980 U.S. Male Population by Age....................................105

23. 1980 U.S. Female Population by Age................................105

24. 1860 Crude Male Death Rates per 1,000 of Population by

Age...........................................................................108

25. 1860 Crude Female Death Rates per 1,000 of Population by

Age...........................................................................108

26. 1870 Crude Male Death Rates per 1,000 of Population by

Age.............................................................................110

27. 1870 Crude Female Death Rates per 1,000 of Population by

Age..........................................................................111

28. Patients by Year and Sex.............................................119

29. Percentage of Patients with Diagnosis Information.............125

30. Percentage of Patients Diagnosed with Debility..................126

31. Percentage of Patient Deaths by Year...............................127

32. Percentage of Patients Converted.....................................128

33. Percentage of Patients who Converted and Died at the

Hos pital. ..................................................................129

34. Patients by Age Group and Year......................................131

35. Male Patients vs. All Adult Patients................................131

36. Female Patients vs. All Patients Ages $0-15 . . . . . . . . . . . . . . . . . .132$

37. Average Ages of Patients by Year and Sex.......................132

38. Average Length of Stay by Year and Sex.......................133

39. Percentage of Patients Associated with the House of

Providence by Year........................................................134 
40. Percentage of Male Patients Listed as Sailor and Miner....136

41. Percentage of Male Patients Listed as Laborer and Farmer.  
CHAPTER I

\section{INTRODUCTION}

America pushed west almost from birth. The drive to secure better and more land was part of the colonial heritage. The yeoman farmer ethos of Jeffersonian times justified the greater majority of the populace in its quest to improve its economic and personal wellbeing. Many Americans moved inland and settled the regions most suited to farming, especially the acreage around river valleys in the Mississippi drainage system. Here land was rich and farming prospects were good. Unfortunately, health conditions were not favorable to human existence. Malaria played havoc with those who settled in the river valleys. The dilemma of economic well-being versus health disaster motivated a number of Americans to seek better living conditions. The belief system that placed the individual ultimately responsible for her or his own condition sent many searching for a better life. Some of these health-seekers sought their goal at the end of the Oregon Trail where unsettled, rich (and free) farm land promised economic prosperity, while the purported mild climate promised good health.

Both prior to and after the white migration to the Pacific Northwest, missionaries were involved in the region. At present-day Vancouver, Washington, two diocesan priests established the St. James Mission to serve Prench-Canadian residents of the region and 
to spread the word of God among the Native Americans. The priests soon requested and received a contingent of sisters to aid them in their missionary endeavors. The Sisters of Charity of Providence (hereafter the Sisters of Providence) came to the mission in 1856 and immediately established institutions that softened the harshness of the frontier. They founded an orphanage, instituted care for the elderly, and started a boarding school. The sisters' work in many ways supported the foundation of the developing community, and in most instances they received unanimous community support. The community service work, especially among the poor and sick, paved the way for the establishment of St. Joseph Hospital in 1858. Its beginnings were humble, closely resembling a cross between an almshouse and a missionary station, since contemporary hospitals were generally outside the realm of professional health care.

The situation in contemporary medical practice was a kaleidoscope of competing sects and contradictory convictions. The mainline profession of medicine, and its techniques and therapies, failed to meet the needs of patients, was viewed as extreme in nature, and provided justification for the competition that opposed it. The training and licensing of "regular" doctors was suspect for a number of reasons. Contemporary traits of self-reliance and a general suspicion of professionals who held themselves above the crowd, promoted the belief that all who made the effort could educate themselves well enough to answer most of their medical needs. Medical sects also challenged the authority and legitimacy of orthodox physicians. Faced with a number of medical options, all of 
which broke down in the face of epidemic disease, Americans searched for better solutions to medical problems.

The publication of health literature was a thriving business in the nineteenth century. Every health advocate possessed a health formula which, if followed, promised an improvement in the individual's life. Most supported methods the common person could relate to: exercise, diet, good food, and cleanliness were all extolled. In general, these self-help books were hostile toward organized medicine and, in true Jacksonian form, held individuals to be primarily responsible for their personal health.

The community in the Pacific Northwest possessed certain characteristics, both demographically and philosophically, that influenced its development. As a generally conservative population which believed strongly in self-reliance, its attitudes and outlook were strongly biased toward individual independence tempered by a sense of community support in times of need. The Sisters of Providence established institutions that answered some of these needs. After its inception, St. Joseph Hospital underwent philosophical and procedural changes that reflected the needs of the community and the movement toward professionalized health care.

Assessing the success of health-seekers is a difficult undertaking. One must address both the population as a demographic group, and its individual beliefs about its new environment. The former depends upon generalized statistics from an inherently biased source, since the ability to correctly identify specific diseases was beyond contemporary technology. On the other hand, observations of 
settlers were often self-fulfilling prophesies that justified their migration; they reflected only romanticized notions of the promised land. Thus, the story is not easily found in either "hard facts" or anecdotal remembrances, but nonetheless exists as part of the Pacific Northwest's heritage. 
CHAPTER II

MIGRATION MOTIVATION

Westward expansion had been a part of Anglo-American culture since early settlement days. Relocation and migration were not exceptional events, since the great interior had land aplenty that provided many Americans with an opportunity to share in the yeoman farmer experience. The early nineteenth century witnessed the settlement of the interior river valleys, including those of the Mississippi, Ohio, and Illinois rivers. Mobility was part of the family settlement pattern in the middle west. 1 Close to mid-century, many of these Midwestern settlers made the decision (again) to go west, this time across the Great American Desert in order to establish new homes in the Oregon territory. While many stayed behind, many others trekked across the vast frontier to claim new lands. Their motives were complex, but the search for better health conditions was an important factor cited by many of the pioneers. One typical story showed a couple who married in Missouri in 1838, relocated to Illinois in 1841, and as "his health being very poor, they moved to Oregon" in 1846.2 Migration was seen as a medical option through

1 William A. Bowen. The Willamette Valley. (Seattle: University of Washington Press, 1978), pp. 17-42.

2Fred Lockley. Conversations with Pioneer Women. (Eugene, OR: Rainy Day Press, 1981), p. 93. 
which the patient was removed from an unhealthy situation. Many stories resembled this pioneer's tale: "My brother...was a frail and sickly child...the doctor said a complete change of climate might be beneficial to him, so, in 1853, when I was 12 years old, he and my brother Daniel started across the plains for Oregon." 3 Credence must be given to these testimonies. Yet without some understanding of the climate from which the pioneers escaped, it is easy to relegate health motivations to a secondary role. It is the burden of this chapter to explore the nineteenth century Midwestern valleys of "health despair" through contemporary writings in order to appreciate the environment from which Oregon immigrants sought relief. Clearly, the search for superior health surroundings was one response to miserable disease conditions which prevailed in the river valleys of the Mississippi drainage system.

\section{LANDS OF PUTRID WATER}

During the early nineteenth century, adventurers and travelers of many nationalities were intrigued by the American wilderness. As they traveled through the United States, many recorded their impressions of the untamed land. From these accounts, the conditions of the interior river systems become a story of rich fertile land often tainted by the label 'unhealthy.' Each traveler pursued her or his purpose during their journey. Prince Maximilian of Wied sought a journey of adventure, while Scotsman

\footnotetext{
${ }^{3}$ Lockley. Conversations with Pioneer Women, p. 18.
} 
and naturalist John Bradbury was commissioned by the Botanical Society of Liverpool to conduct plant life research in the North American interior. Americans Timothy Flint and Daniel Drake attempted to contribute definitive regional works based on extensive research in the Mississippi Valley. To be sure, many of these works were romanticized accounts and contain (by today's standards) inaccurate scientific observations. Nonetheless, they provide a context about the geography, beliefs and observations of conditions in early America.

The most consistent observation by those who traveled through the region concerned the stagnant water which plagued the area. Concerning the lower courses of the Ohio, the Wabash, the Tennessee, the Mississippi and its southern tributaries, in short, wherever the rivers overflowed and left waters carried off only by evaporation or the slope of land inhibited drainage, the general maxim was that such locations were unhealthy. ${ }^{4}$ Medical theories of the era put much credence into the belief of 'vapors' and 'miasma' which rose from poisoned waters and caused illness to those who breathed their fumes. As vast quantities of mud and vegetable matters were exposed to the heat of the sun, a rapid decomposition immediately commenced. Gaseous constituents developed and gave a

${ }^{4}$ Timothy Flint. The History and Geography of the Mississippi Valley. Cincinnati: E.H. Flint and L.R. Lincoln; 1832. (in two volumes, second edition), p. 35 . 
perceptible taint to the air. These vapors were believed responsible for endemic illnesses, in particular various types of fever. ${ }^{5}$

Putrid waters were not limited to low-lying lands; even the plains experienced inadequate drainage. The very rich and extensive alluvial prairies of the upper Mississippi and Illinois were covered with a prodigious growth of grass, but generally contained marshy basins where the water from the high lands was retained. Many had hoped that the openness of the plains and exposure to the winds would exempt the lands from the problems associated with the bottoms, especially since "their extraordinary fertility, and their being at once ready for the plough," were alluring to immigrants. 6

Thus, the dilemma of the natural environment was evident to all. The settler was offered the chance at rich farm land in exchange for his health and that of his family. Every report noted that in the southern and middle regions of the Mississippi valley, the wide, level, and heavily timbered alluvions were generally unhealthy. In these situations, the new resident was subject to many complaints, but in particular, the "fever and ague," which writers noted was "the general scourge of the valley."7

Every state these rivers touched reported their sufferings. In town after town, from the mouth of the Mississippi to the shores of

5 James Flint. "Letters from America" in Early Western Travels 1748-1846, Ruben Gold Thwaites editor, Vol. IX, (Cleveland: McArthur H. Clark Co., 1904), p. 189.

${ }^{6}$ Flint, History and Geography of the Mississippi Valley. p. 36.

7 Flint, History and Geography of the Mississippi Valley. p. 37. 
Lake Erie, generally poor health conditions were consistently reported. In 1819, Louisville, Kentucky described "much wet ground" resulting in intermittent fevers that afflicted the inhabitants at the end of summer and in fall. 8 Large portions of southern Illinois, lying between the Illinois River and the Mississippi River, contained rich soil and were interspersed with prairies, but were subject to disease. 9 On the Scioto River in southern Ohio, inhabitants were "occasionally visited by agues." 10 At the falls of the Ohio River it was reported that a considerable number of persons were "carried off" by fevers.11 In Portland, Michigan on the southwestern shore of Lake Erie, "many meagre convalescents are to be seen walking about the street." 12 At the mouth of the Niagara, "the people are said to be much afflicted with ague, a complaint common to both sides of the river."13 Putnam and Marshall counties in Mllinois reported illnesses

${ }^{8}$ At or near Louisville KY 17 Feb. 1819. J. Flint, "Letters from America" in Early Western Travels, p. 163. 186.

9. Flint, "Letters from America" in Early Western Travels. p.

10 Pickaway Plains on Scioto River. J. Flint, "Letters from America" in Early Western Travels, p. 304.

${ }^{11}$ At the falls of the Ohio. J. Flint, "Letters from America" in Early Western Travels, p. 287. 311.

12J. Flint, "Letters from America" in Early Western Travels, p. 13J. Plint, "Letters from America" in Early Western Travels, p. 321. 
that "sorely afflicted the pioneers," particularly in 1838 and in 1849.14

When travelers crossed regions of beautiful, lush countryside, they solicited the testimony of nearby residents before passing judgment on the salubrity of an area. As one writer noted, "A stranger would suppose it healthy, but my information respecting it was rather the reverse, particularly in the autumnal months, when it is subject to bilious disorders." 15 Yet it was not the favorable conditions that provided the richest rhetoric. For example, this vivid description by one traveler relates both a visual and an olfactory experience:

There were but few farms along my route, and the tenants of those with whom I chanced to meet betrayed too plainly, by their ghastly visages, and their withered, ague-racked limbs, the deadly influences of the atmosphere they inhaled. As I wandered through this region, where vegetation, towering in all its rank and monstrous forms, gave evidence of a soil too unnaturally fertile for culture by man...I thought I could perceive a deadly miasma stealing over my frame, and that every respiration was a draught of the floating pestilence. I urged onward my horse, as if by flight to leave behind me the fatal contagion which seemed hovering on every side; as if to burst through the poisonous vapours which seemed distilling from every giant upas along my path. That this region should be subject to disease and death is a circumstance by no means singular. Indeed, it seems only unaccountable to the traveler that it may be in habited at all. 16

${ }^{14}$ Isaac Rawlings. The Rise and Fall of Disease in Mllinois, 2 Vol. (Springfield: State Department of Public Health, 1927), p. 42.

${ }^{15}$ Fortescue Cuming, "sketches of a Tour to the Western Country" in Early Western Travels, Vol. IV, p. 315.

${ }^{16}$ Edmund Flagg. "The Far West" in Early Western Travels, Vol. XXVII, Part II, p. 94. 
HOW TO FIND A HEALTHY HOME SITE

Although many acknowledged the detrimental aspects of life in the river valleys of the Middle West, nobody advocated that white settlers should abandon the region. Indeed, many were willing to share with potential immigrants a successful formula for selecting lands in these rich river valleys. Travel guides and other literature time and again warned that locations where the rivers overflowed and left stagnant waters, or where ponds and lagoons in the bottoms retained rain waters, were unhealthy.17 Immigrants were warned that the most dangerous health conditions occurred when residences were located on creeping bayous or on the rich and heavy timbered alluvion. Yet because of their fertility and the ease with which these lands were brought into cultivation, they were the sites initially selected. One writer warned "the rich plains of the Scioto [River] were the graves of the first settlers."18 Thus, the settlers faced a significant dilemma. Wherever the lands were extremely fertile, it seemed that they were also "generally sickly."19

Unfortunately, higher elevations did not solve this dilemma for the immigrants. Many found that bluff sites on the margins of wide bottoms and alluvial prairies proved to be as unhealthy as those in the bottoms or prairies which they overlooked. "This fact has been

${ }^{17}$ Flint, History and Geography of the Mississippi Valley, p. 35.

18 Flint, History and Geography of the Mississippi Valley, p. 35.

${ }^{19}$ Flint, History and Geography of the Mississippi Valley, p. 36. 
amply demonstrated on the Ohio bottoms and bluffs, on the margins of the alluvial prairies of the upper Mississippi, and, in short, wherever a high bluff overlooks a wide bottom."20

In order to solve this predicament, settlers were urged to place health before economics. Many writers strongly suggested that to regard the salubrity of residence was a consideration of more importance than its fertility or vicinity to a market. 21 Peck's Guide for Emigrants noted that while farmers instinctively sought fertile land in the vicinity of a market, it was more advisable to first secure a healthy environment if they valued their own health, and that of their families. 22

\section{THE CHIEF CULPRIT}

Among all epidemics, the "fever and ague" was "the scourge of the West."23 And scourge it was, even more so than nineteenth century contemporaries realized. The afflictions they identified as distinct illnesses (such as "remittent fever", "intermittent fever", and "bilious fever" to name a few) were in most cases the same that they called the "fever and ague." Today we know this disease as malaria. The varied characteristics and symptoms of malarial fever

20 Flint, History and Geography of the Mississippi Valley, p. 38. 193.

${ }^{21}$ Flint, History and Geography of the Mississippi Valley, p.

22John M. Peck. Mid-American Frontier: A Guide for Emigrants, (New York: Arno Press, 1975, 1831), pp. 214-215.

${ }^{23}$ Flagg, "The Far West" in Early Western Travels, p . 96. 
for the most part explain why it was so often identified as different illnesses.

Malaria is a serious parasitic disease spread by the bite of mosquitoes. The disease produces severe fever and, in some cases, complications affecting the kidneys, liver, brain, and blood that can be fatal. The symptoms appear only when red blood cells infected with parasites rupture to release more parasites into the blood stream. Malarial fever has three stages. The first stage is marked by chills and uncontrollable shivering. The second phase is characterized by fever, i. e., an elevated body temperature which may reach $105^{\circ}$. The last stage is indicated by profuse sweating, which lowers the body temperature. A severe headache, general malaise, and vomiting may accompany the attack. In many cases, the parasitized red blood cells rupture at the same time in each cycle and the fever develops cyclically, occurring every other day or every third day. 24

The dangers of disease were often humanized and embodied as cognitive entities or menacing forces waiting to attack all who dared to trespass into new lands. Ever since settlers first looked west, they faced many uncertainties: they braved danger on the trail; they faced hostile Indians who lurked in the woods. And if these were not enough to strike terror into their hearts, disease stalked them in

${ }^{24}$ The American Nedical Association, Encyclopedia of Medicine. Charles Clayman Ed. (New York: Random House, 1989), p. 659. 
the lowlands.25 Many writers described the illnesses of the interior valleys in terms that suggested the presence of an intelligent entity; a formidable enemy capable of assuming a variety of shapes. In Vermilion County, Illinois, illness "sought out and attacked every new comer for twenty-five years in the form of fevers, fever and ague and bowel complaints." 26

Often the enemy successfully defended its territory and forced the pioneers off the land. On Beaver Creek in Illinois, it was reported that a colony of Norwegians were stricken with the "prevailing illness" of the lowlands. Fifty perished and the survivors abandoned the settlement. 27 Local politicians believed that the population of the Tllinois villages of Fort Chartres, St. Philips and Prairie $\mathrm{du}$ Pont in 1812 exceeded that of 1838. This outward migration and depopulation was attributed to bad health resulting from standing waters. One writer noted "The once flourishing villages of Fort Chartres, St. Philips and Prairie du Pont are only known by the ruins and the inscriptions over the dead."28

25 Arthur C. Boggess. The Settlement of Hlinois, 1778-1830, (Chicago: Chicago Historical Society Collection, 1908) Vol. V quoted in Rawlings, Rise and Fall of Disease in Illinois, p. 30.

${ }^{26}$ Rawlings, Rise and Fall of Disease, p. 42.

${ }^{27}$ Rawlings, Rise and Fall of Disease, p. 42.

${ }^{28}$ Rawlings, Rise and Fall of Disease, p. 34. 


\section{Shattered Appearance}

Malaria left telltale signs among its sufferers, and even those who lacked medical training could easily spot its victims. Travelers judged the salubrity of the region by the appearance of the residents and not by their testimony. Illinois visitor Henry Schoolcraft wrote, "The appearance of the inhabitants has corresponded with the opinion before expressed of the unhealthiness of the country. Pale emaciated countenances; females shivering with ague, or burning with intermittent fever...and sometimes, every member of a numerous family suffering from the prevalent malady at the same time." 29

While malaria attacked all age groups without discrimination, most writers noted that the greater health damage was incurred by the young and the strong. Their observations reflected a sympathetic recognition of economic hardship and the uncertainty of future generations. Since hard physical labor was critical to success of the family, "the strong" were pivotal anchors of survival, while "the young" offered some hope of familial persistence. Surviving sufferers were frequently rendered unfit for labor for three to six months and received an "irreparable injury to their constitutions." 30

${ }^{29}$ Henry R. Schoolcraft "A Journey Up the Illinois River in $1821 "$ in Pictures of Mllinois One-Hundred Years Ago, Milo M. Quaife, ed. (Chicago: R.R. Donnelley \& Sons Co., 19.18 quoted in Rawlings, Rise and Fall of Disease, p. 31.

${ }^{30}$ Flint, History and Geography of Mississippi Valley, p. 288. 
Travelers wrote of the pale sallow countenances and shattered appearance of Midwestern residents. Certain characteristics of malaria were memorable to diarists. One woman, impressed by her guest's affliction, recorded that his case "beat all the shakes she ever see. He shuk the hull cabin."31 Arthur Boggess provided his readers with a vivid appreciation of conditions and appearances of settlers in Illinois. He wrote, "Buried in the depth of a boundless forest, the breeze of health never reaches these poor wanderers...They are tall and pale-like vegetables that grow in a vault pining for light; a squalling tribe of dirty brats that are of one pale yellow, without the slightest hint of healthful bloom."32

Malaria was perceived as more than simply a prevalent illness which afflicted settlers. It encompassed a population and held them captive. Dr. Victor C. Vaughan recalled that in 1865, every man, woman, and child he saw in southern Illinois, shook with ague every other day. For this doctor, these residents suffered from more than just an endemic disease, they were "people held in bondage."33

\section{Sickly Season}

In the valley, the native illness of "fever and ague" was part of the life cycle. Reports from every part of the region related the

${ }^{31}$ Rawlings, Rise and Fall of Disease, p. 35.

${ }^{32}$ Boggess, Settlement of Illinois quoted in Rawlings, Rise and Fall of Disease, p. 29.

${ }^{33}$ Rawlings, Rise and Fall of Disease, p. 42. 
Travelers wrote of the pale sallow countenances and shattered appearance of Midwestern residents. Certain characteristics of malaria were memorable to diarists. One woman, impressed by her guest's affliction, recorded that his case "beat all the shakes she ever see. He shuk the hull cabin."31 Arthur Boggess provided his readers with a vivid appreciation of conditions and appearances of settlers in Illinois. He wrote, "Buried in the depth of a boundless forest, the breeze of health never reaches these poor wanderers...They are tall and pale-like vegetables that grow in a vault pining for light; a squalling tribe of dirty brats that are of one pale yellow, without the slightest hint of healthful bloom."32

Malaria was perceived as more than simply a prevalent illness which afflicted settlers. It encompassed a population and held them captive. Dr. Victor C. Vaughan recalled that in 1865 , every man, woman, and child he saw in southern Illinois, shook with ague every other day. For this doctor, these residents suffered from more than just an endemic disease, they were "people held in bondage."33

\section{Sickly Season}

In the valley, the native illness of "fever and ague" was part of the life cycle. Reports from every part of the region related the

${ }^{31}$ Rawlings, Rise and Fall of Disease, p. 35.

32 Boggess, Settlement of Illinois quoted in Rawlings, Rise and Fall of Disease, p. 29.

${ }^{33}$ Rawlings, Rise and Fall of Disease, p. 42. 
same story: in the summer and autumn months, fevers prevailed. 34 As one pioneer woman wrote, "It came with perfect regularity."35 With the subsiding of the flood waters, the sickly season commenced, and lasted from July to October inclusive, leaving the impression that the driest seasons were the most unhealthy. ${ }^{36}$ Nost held that when the stagnant waters were exposed to the intense ardor of the sun, sickness was the natural result. Ironically, one writer noted that during the sickly season "the mosquitoes are excessively troublesome."37 There was significant support for the position that 'the sickly months' were part of a regional calendar. 38

\section{$\underline{\text { Seasoning }}$}

All newcomers were subject to what was termed "a seasoning," after which they could look forward to annual attacks of the scourge of the valley.39 Persons unaccustomed to the climate of the lower Mississippi country took serious health risks if they visited there in the summer or fall. 40 Strangers and newcomers alike were attacked

${ }^{34}$ Flint, History and Geography of Mississippi, p. 40.

35 Rawlings, Rise and Fall of Disease, p. 31.

${ }^{36}$ Cuming. "Sketches of a Tour " in Early Western Travels, p. 349.

${ }^{37}$ Flint, History and Geography of Mississippi, p. 281.

${ }^{38}$ Flint, History and Geography of Mississippi, p. 41.

${ }^{39}$ Cuming, "Sketches of a Tour" in Early Western Travels, p 349.

${ }^{40}$ Peck, Mid-American Prontier, p. 222. 
with a greater violence than those acclimated, yet all attacked found that the illness seldom left "the constitution more than the wreck of what it was in health."41 whenever an unacclimated family settled itself in the vicinity of the river valleys, it could count upon sickness. 42 Unfortunately, many did not survive their seasoning. During the sickly months, few strangers escaped exposure, which frequently proved fatal. 43

Immigration and settlement into the wilderness of the Midwest was not a decision to be taken lightly or without due respect for the consequences. Peck warned, "Let then none come to Illinois who do not expect to be sick and to die, whenever Divine providence shall see fit so to order events." 44

\section{Blame the Victim}

Everyone recognized that the health conditions were less than satisfactory, and yet determined immigrants still came. Many survived and some even prospered. This represented a contradiction and dilemma for many observers. How were some able to overcome the known hardships and health conditions to prosper while others succumbed to the circumstances? Contemporary writers such as Peck often looked to blame the victim for personal failings that resulted

41 Peck, Mid-American Frontier, p. 207.

42 Flint, History and Geography of Mississippi, p 295.

${ }^{43}$ Cuming, "Sketches of a Tour" in Early Western Travels, p. 321.

${ }^{44}$ Peck, Mid-American Frontier, p. 242. 
in his own downfall. "I have no doubt that more than one half of the cases of sickness and death arise from imprudence and bad management, or the want of proper nursing."45 It was believed that, in addition to poor site selection, toil, privation, imprudence, carelessness, and exposure hurried many settlers prematurely to their graves. 46 Wherever settlers neglected proper attention to the precautionary means for the preservation of health, residents were placed in an "unnecessary state of liability to disease."47

If the failures of the region could be blamed on the victim, further immigrants could rationally decide upon such a course as long as they avoided the pitfalls of earlier settlers. It was perhaps easier to blame people for their own health problems than to admit any human inability to conquer this environment. Poor location, unfit dwellings, inappropriate food, and inadequate clothing were just some of the factors that contributed to health problems of the immigrants. Poorer settlers frequently suffered from "the want, during the summer season particularly, of substantial food," which hindered their survival. 48 often this was attributed to their own indolence. Some believed that much disease, especially in the more recently settled parts of this country, was due simply to neglect of

${ }^{45}$ Peck, Mid-American Frontier, p. 234.

${ }^{46}$ Peck, Mid-American Frontier, p. 226.

47 Peck, Mid-American Frontier, p. 211.

${ }^{48}$ Peck, Mid-American Frontier, p. 216. 
precautionary measures, sometimes because of misdirected industry, and sometimes because of laziness or evil habits. 49

Simple precautions such as clean water, a stout cabin and ample provisions were the settlers' first priority. Since these were basic survival tactics, it was easy to believe that even the poorest immigrant could avoid distress unless seduced "by the fantasies of his own brain to an unhealthy and desolate situation." 50 some were convinced that many Midwestern immigrants scarcely ever paused long enough, or took sufficient elements into their calculation, for the selection of their residence, especially with a view to its salubrity. It was assumed that when they had made their choice, the settlers had been encumbered with families, stinted both in time and money, and hurried to commence operations in order to provide sustenance for their families. Under these conditions, settlers were apt to give too little weight to the most important motive of all, which ought to determine their election. Thus, it was rationalized that the general conditions involved in relocation such as an uncertain climate, the influences of a new diet and regimen, the fatigue of severe labor, and exposure were perhaps more responsible for the general reputation of unhealthiness than were the endemic diseases themselves. 51 The settlers were urged "to depend for health on temperance, moderation in all things, careful conformity in food

\footnotetext{
${ }^{49}$ Peck, Mid-American Frontier, p. 218.

50 Peck, Mid-American Frontier, pp. 218-219.

51 Flint, History and Geography of Mississippi, p. 37.
} 
and dress to circumstances and the climate." 52 where "the people were imprudent and exposed" is where they suffered "extraordinary mortality." 53

Those who lacked the economic means to secure a "healthy site" and settled wherever they could, were blamed for their failings. "There are many people who act as if they were not sufficiently sensible of the disadvantages resulting from settling in unhealthy situations." 54 Yet, generally it was economics, more so than health, that determined the homestead site. While the new settler could not expect to avoid all disease, a judicious choice of a situation would render him and his family less liable to its attacks. However, many settlers considered superior soil fertility and transportation facilities first. Others believed that such considerations sacrificed good health to economic interests. 55

The health conditions of the river valleys were more than simply miserable. They represented a dilemma for those who lived, and those who sought to live in the region. Contemporaries both pitied and blamed the settlers for their plight. The immigrants were victims who were yet somehow responsible for the health

52 Flint, History and Geography of Mississippi, p. 193.

${ }^{53}$ Flint, History and Geography of Mississippi, p. 295.

54J. Flint, "Letters from America" in Early Western Travels, p. 287-88.

55 John Bradbury. "Travels in the Interior of America" in Early Western Travels, p. 311. 
environment. Some believed that many pioneers pitted their economic interests against their ultimate survival. As one writer noted, "most of the diseases peculiar to the West are superinduced by imprudence, ignorance, or negligence in nursing." 56 The poorer immigrants were especially viewed as most responsible for their ills. Because of their unfavorable financial situation, these settlers lacked the means of securing the 'better home sites' or adequate food and clothing, and precisely because of this, they suffered the devastation of disease. Often the health woes of settlers were ascribed to nothing but their own imprudence. 57 Given the opportunity and the means of securing both good land and good health in Oregon, it is not surprising that many Midwestern farmers chose to move on.

56Flagg, "The Far West" in Early Western Travels, p. 95. 57 Rawlings, Rise and Fall of Disease, p. 41. 
CHAPTER III

ST. JAMES MISSION

The westward migration of pioneers to the Oregon Territory was both preceded and followed by missionaries. The initial missionary movement sought to convert Native American groups, while the latter continued the earlier work and brought traditional institutions to the American frontier for white settlers.

In November 1838, a Catholic mission was established north of the Columbia River in present day Vancouver, Washington. During this era, sovereignty of the Oregon Territory was still undetermined. The Anglo-American-French-Canadian community in the nearby vicinity was small. A pair of diocesan priests used the St. James Mission as a base of operation for their work among the Native Americans.

During the $1840 \mathrm{~s}, 1850 \mathrm{~s}$, and $1860 \mathrm{~s}$, overland migration brought a large influx of white settlers to the Pacific Northwest, and thus significantly changed the cuitural environment of the region. Many of the new inhabitants sought economic opportunities, while others were escaping the health conditions of the eastern river valley systems.

In order to better serve the needs of the new American settlers and to expand missionary activity among the Native Americans, the priests at St. James requested support personnel to 
augment their work at the mission. The Mother House of the Sisters of Providence in Montreal responded to the call. On December 8, 1856, five sisters led by Sister Joseph of the Sacred Heart (superior of the new western foundation) arrived in Vancouver to begin their missionary work among all the inhabitants of the region. ${ }^{1}$ Their goals and methods were consistent with nineteenth century missionary aspirations. The Sisters of Providence sought to spread the gospel, to educate, to help the sick and to relieve the poor. Yet they did more than bring a religious organization to the Pacific Northwest. The Sisters brought social institutions that curbed the harsh realities of frontier life. Many of the organizations they founded were the first of their kind in the region. These Sisters were true to their mission. In response to their works, the community came to recognize the valuable contributions of the Sisters of Providence in the Pacific Northwest. On January 28, 1859, the Sisters of Providence became one of the first corporate bodies recognized in Washington Territory. Their express purpose was the "relief of needy and suffering humanity...the care of orphans, invalids, sick and poor, and...the education of youth." 2 The sisters were thus dedicated to softening the edges of the hardnesses of life in a new place. They laid the foundations of social institutions established by the Sisters in Vancouver, Washington. The institutions in question not only

1 Mary McCrosson. The Bell and the River. (Palo Alto: Pacific Books, Publishers; 195.7), p. 15.

2"Act of Incorporation, 1959" MSS 22 (Seattle: Sisters of Providence Archives) 
served the frontier community but also created a unique community at the St. James mission, namely that of the House of Providence. This foundation played a critical social role in the establishment of an expanding Anglo-American community in the Pacific Northwest.

\section{THE BEGINNINGS}

\section{The Orphanage}

The Sisters founded an orphanage and a school at the mission less than six months after their arrival. The girls' boarding school complemented a similar institution for boys established in 1856 by the diocesan priests. Providence of the Holy Angels opened its doors April 15, 1857 and at that time seven girls were accepted as students. $^{3}$ But it was clear almost immediately that the community needed more than just an educational institute. Sister Joseph was quick to assess the situation and reported to her ecclesiastical superiors that:

...it looks as if we can count on a good number of children...More and more I feel that I shall be happy only in contacting and relieving the destitute...the greater number of our boarders are orphans, and we can expect many more...Any institution with sure means of subsistence which could receive such children would do a great deal of good. 4

Thus, the Sisters established the first care facilities for orphans in the Washington Territory. The asylum accepted children of both

\footnotetext{
${ }^{3} \mathrm{McC}$ rosson, The Bell and The River, p. 121.

${ }^{4}$ McCrosson, The Bell and The River, pp. 129-130.
} 
sexes as well as those of inter-racial heritage. During the 1860 s and 1870s, the orphanage served the ever increasing regional needs. For example, the 1860 Census records for Clark County reveal that of the 37 orphans listed as resident of the asylum, $87 \%$ originated in Washington Territory, $11 \%$ were from Oregon while $2 \%$ were from other regions. 5 The Census of 1870 listed sixty-two orphans of which $42 \%$ were drawn from Washington Territory, $43 \%$ from Oregon and $15 \%$ from other regions. 6 The records of the orphanage kept by the Sisters reveal that the number of children under the care of the House of Providence rose steadily throughout most of the $1860 \mathrm{~s}$, although they experienced a slight decline in 1868-1869.7 The orphanage fulfilled the social and economic needs of the destitute and abandoned children in the Pacific Northwest. Besides the House of Providence, only one other benevolent institution (Children's Home established in 1867 by the Ladies Relief Society in Portland)

5 Mildred Porter, compiler. United States Census of the Washington Territory 1860, Clark County. (Vancouver: Clark County Genealogical Society, 1982), pp. 28-29.

6 Mildred Porter, compiler. United States Census of the Washington Territory 1870, Clark County. (Vancouver: Clark County Genealogical Society, 1982), pp. 60-62. 23\% of the 62 orphans were of mixed racial heritage.

${ }^{7}$ All figures in this chapter on the institutions at the St. James Mission have been compiled using statistics recorded yearly by the Sisters in "Chronicles of the Provincial House" MSS 22 (Seattle: Sisters of Providence Archives) 
appeared on the roles of recognized institutions in either Washington Territory or Oregon. 8

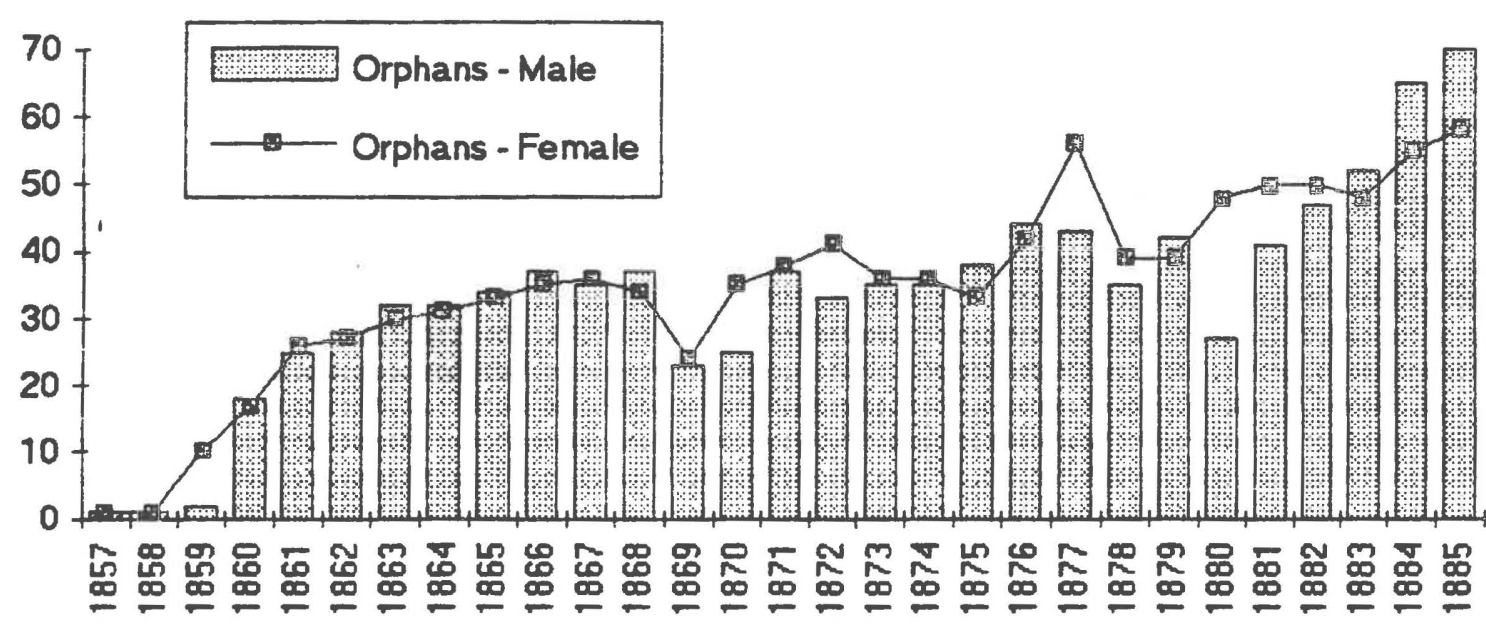

Figure 1. Orphans of the House of Providence.

The orphans were originally housed on the mission grounds wherever space could be found. This situation was clearly not ideal, and the sisters responded by erecting a new structure for the orphan boys, which they dedicated to St. Vincent in February 1860. The girls continued to be housed in an assortment of places on the mission grounds. As the number of orphans grew, the sisters sought additional bed space. Another structure, contained on a half block tract of land which the sisters had purchased near the mission, provided room for expansion. The renovated building became the new St. Vincent Orphanage for boys in December 1860, while the former

${ }^{8}$ Dept. of Commerce Bureau of the Census. Benevolent Institutions 1910. (Washington D.C.: Government Printing Office, 1913), pp. 140, 168, 172. 
St. Vincent building was re-christened St. Genevieve's and provided shelter for the orphan girls. 9

The orphanages of the House of Providence were unique institutions which filled the needs of the region. In a number of ways, the community acknowledged the contribution of the sisters and their work with orphans. One local newspaper editor wrote:

The Orphan Asylums are made up partly of scholars whose relatives pay tuition, and partly of those who have no friends but God and the good Sisters. The majority are orphans in deed and in truth, and might fare very badly if the Sisters did not extend them the hand of charity. 10

The School

While the orphanage immediately answered community needs and drew its support, the Sisters' school originally faced opposition and criticism from the local community. The French-Canadian nuns faced several obstacles during their initial forays into education, not the least of which was a language barrier. Additionally, traditional American nineteenth century anti-Catholic sentiments pervaded the region. Sister Joseph believed that the sisters had to prove themselves to the community before they achieved full acceptance. In letters to her superiors, she wrote:

${ }^{9}$ Mary Claver Morrow. "Providence of the Holy Angels Vancouver, WA 1856 - 1874" (no date) Unpublished paper MSS 22 (Seattle: Sisters of Providence Archives), p. 15.

${ }^{10}$ Vancouver Register 30 Jan $1869,2: 1$. 


\begin{abstract}
We have had some prejudice to overcome; our incompetence was openly discussed in our first years, particularly by the public who proclaimed that our school was of no value except for beginners. That pleases me because I feel confident that this little humiliation is good for us...I believe...that we must exert ourselves to become better equipped for teaching. 11
\end{abstract}

Such sentiment led to somewhat innovative plans for the girls' boarding school. Sister Joseph championed her version of a "magnet program" centered on the belief that music lessons would add a distinctive character and thus draw attention to the institution. In correspondence with the Mother House, she repeatedly requested additional staff but especially a music teacher, through which her goals might be realized. In October of 1858 , three additional sisters arrived at the mission. This contingent not only improved the English language abilities of the staff, but also brought a qualified music teacher as well. 12

By 1868, the community seemed generally convinced that the Sisters provided the girls of the Pacific Northwest with a satisfactory education. The academic accomplishments of the students adequately satisfied both the local educational requirements as well as the conscientious concerns of the native white community. After the annual public examination of students, one local newspaper reported:

11 McCrosson, The Bell and The River, p. 150.

12 McCrosson, The Bell and The River, pp. 120, 151. 
We regret that we are unable from want of space to give a detailed account of the examination of the young ladies who are under the tutelage of the Sisters...Suffice it to say that the utmost satisfaction was expressed at the progress indicated...Among the successful competitors for first prizes we were pleased to notice many orphans. Altogether no more satisfactory examination ever took place in that institution and its effect will be to increase still further in popularity. 13

Providence Academy contributed to the local educational scene in many ways. It had a unique curriculum which included music lessons as well as French language courses. "No undue influence" was "exercised over the religious opinions of the pupils" although "for the maintenance of good order" all students participated in religious activities when required.14 The academy provided an alternative to public education for the local community and attracted day students in addition to the full time boarders. For example, the average number of day-only pupils during the 1860 s was 40 . This average rose slightly during the 1870 s to 43 and made a dramatic jump to 72 during the first half of the 1880s. Boarding pupils represented a generally stable population at Providence Academy. During the 1860s, 1870s, and the first half of the 1880s, annual boarders averaged 21,22 , and 20 respectively. Thus, the sisters had not only a continuous community of boarding pupils but were steadily increasing their enrollment with children from the surrounding vicinity as well.

${ }^{13}$ Vancouver Register 4 July $18683: 1$.

${ }^{14}$ Vancouver Register 11 July $1868 \quad 4: 4$. 
Information for some years was not available

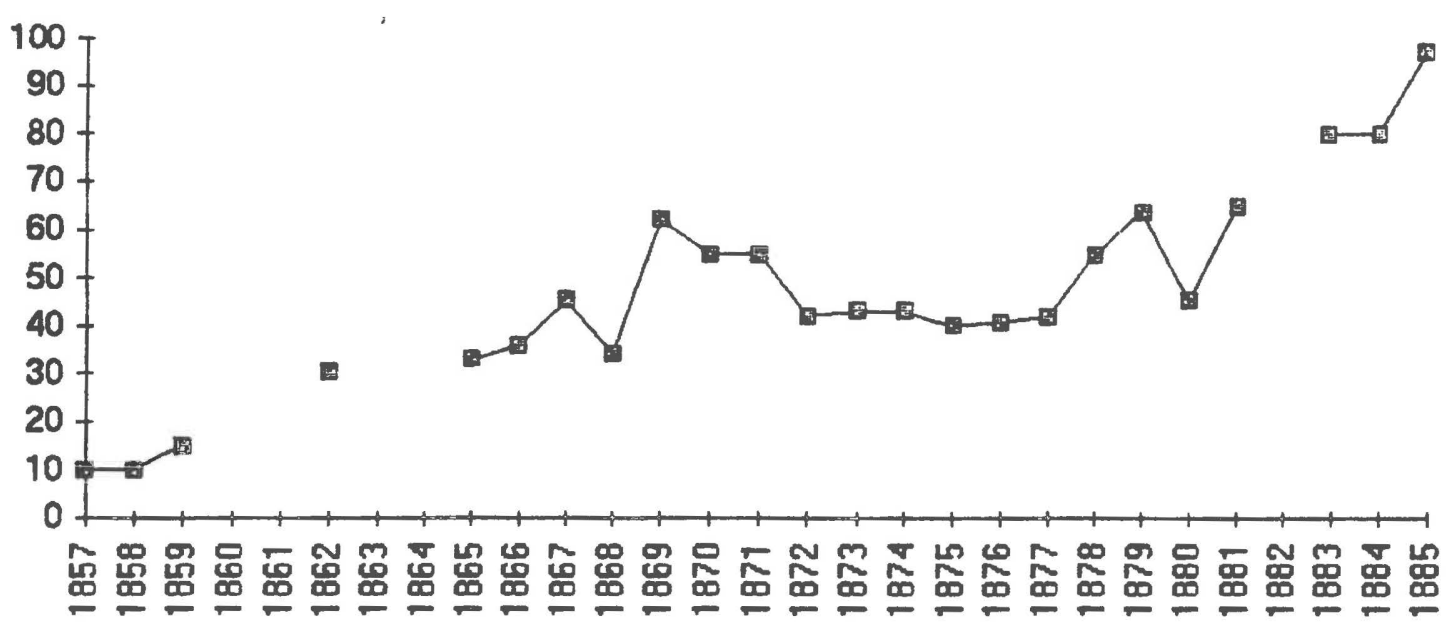

Figure 2. Day pupils at Providence Academy.

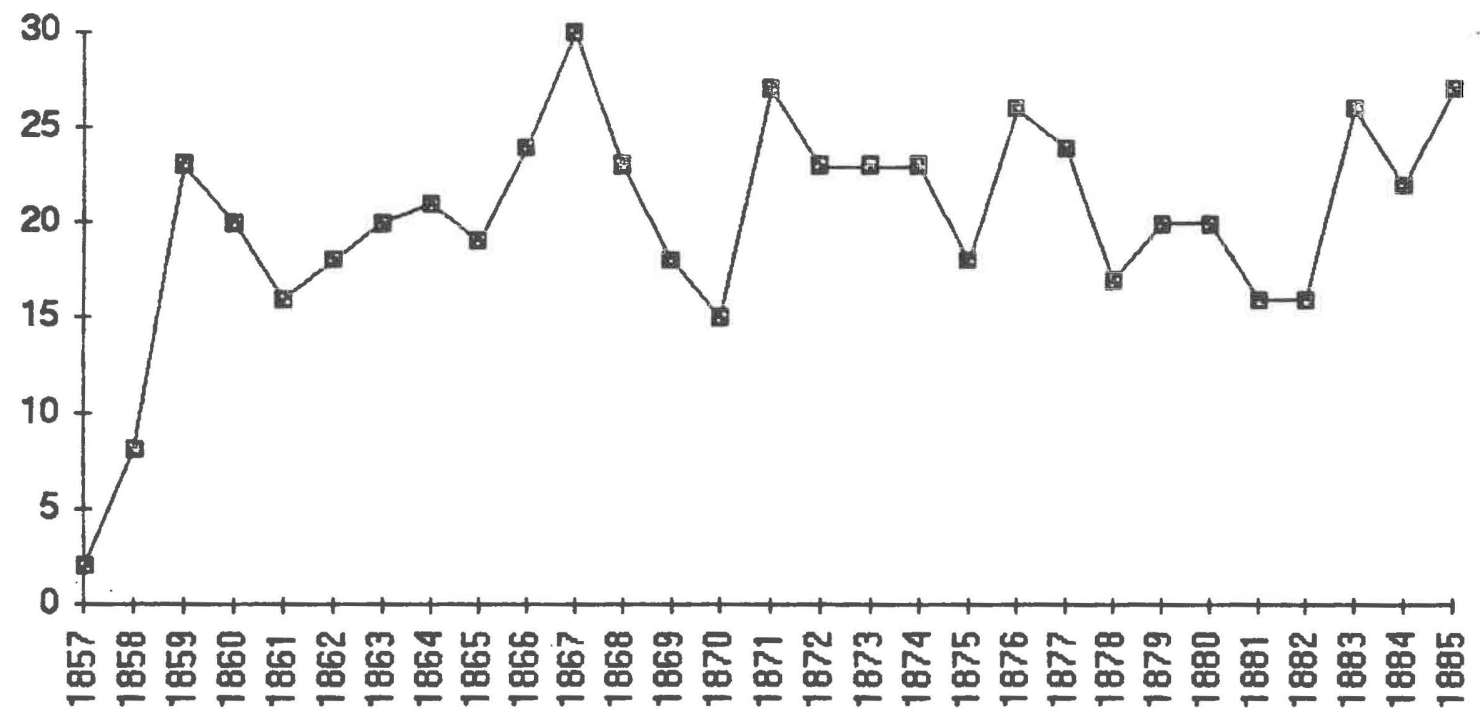

Figure 3. Boarding pupils at Providence Academy. 
Care of the Elderly

As in the case of the orphanage, the establishment of care for the elderly was a charter endeavor of the Sisters of Providence at the St. James Mission. Their work in this area was unique and preceded the foundation of any adult care facility in the Pacific Northwest by 30 years. 15 Like the orphans, the elderly were housed wherever sufficient room was available. Many of the outbuildings on the mission grounds were dedicated either to care of the elders or to the care of the orphan children. 16 Adult care represented a smaller undertaking than that of the orphanage and thus required fewer resources. However, the supportive hand extended by the Sisters to the destitute or homeless elderly directly answered the local area need for expanded social institutions. The number of elderly in residence was a small but steady class during the 1860 s and 1870 s which annually averaged 5 and 6 "guests" respectively. Beginning in 1878, and throughout the first half of the $1880 \mathrm{~s}$, the average number of elderly guests jumped to 14 with a sharp increase in the number of male residents residing with the Sisters.

${ }^{15}$ U.S. Dept. of Commerce. Benevolent Institutions, pp. 236, 254. In 1889 the Maria Beard Deaconess Old People's Home conducted by the Methodist Episcopal Church was founded in Spokane. In 1887 the Patton Home for the Friendless conducted by a private corporation which received "Aged men and women" (but not "colored" persons) was founded in Portland.

16 See Figures 5 and 6, St. James Mission ca 1874. Source: Bryn Thomas. An Archaeological Assessment of the St. James Mission Property, Vancouver Washington. (Cheney: Eastern Washington University Reports in Archaeology and History, 1984), pp. 41-42. 
New facilities completed in 1874 most likely contributed to the expanded population of elderly patients.

Information for 1877 was not available.

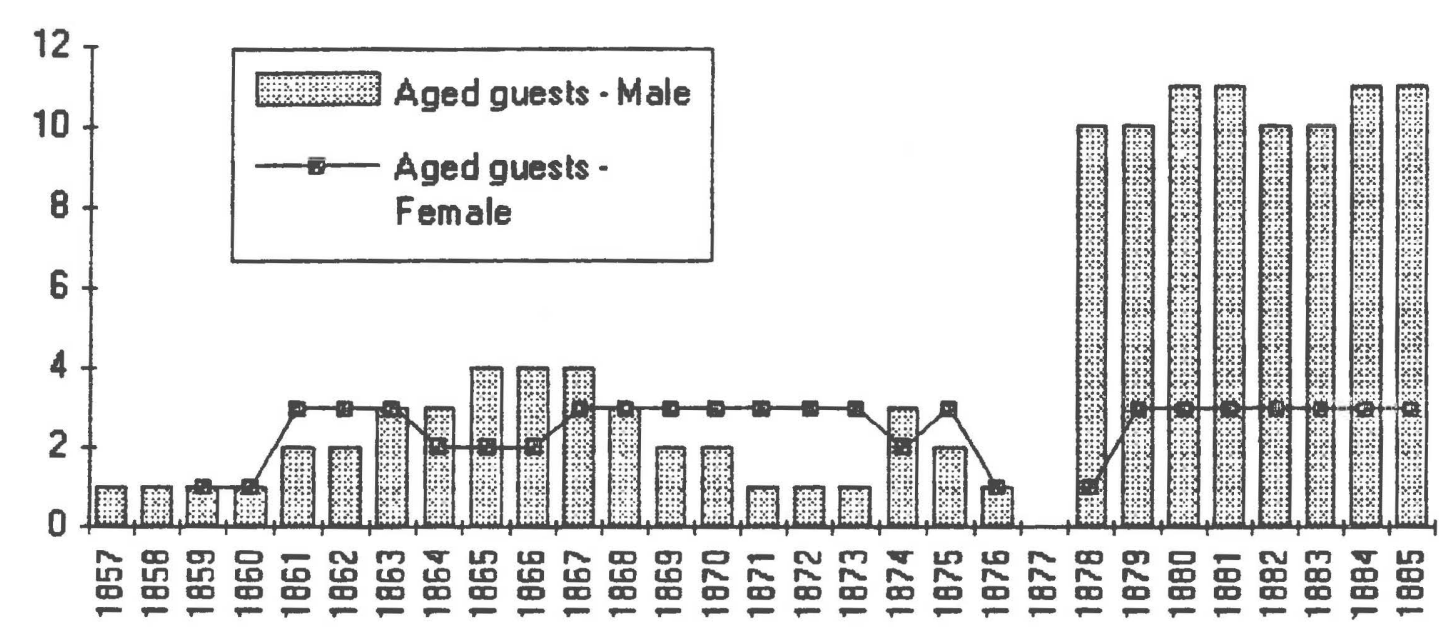

Figure 4. Aged guests of the House of Providence. 


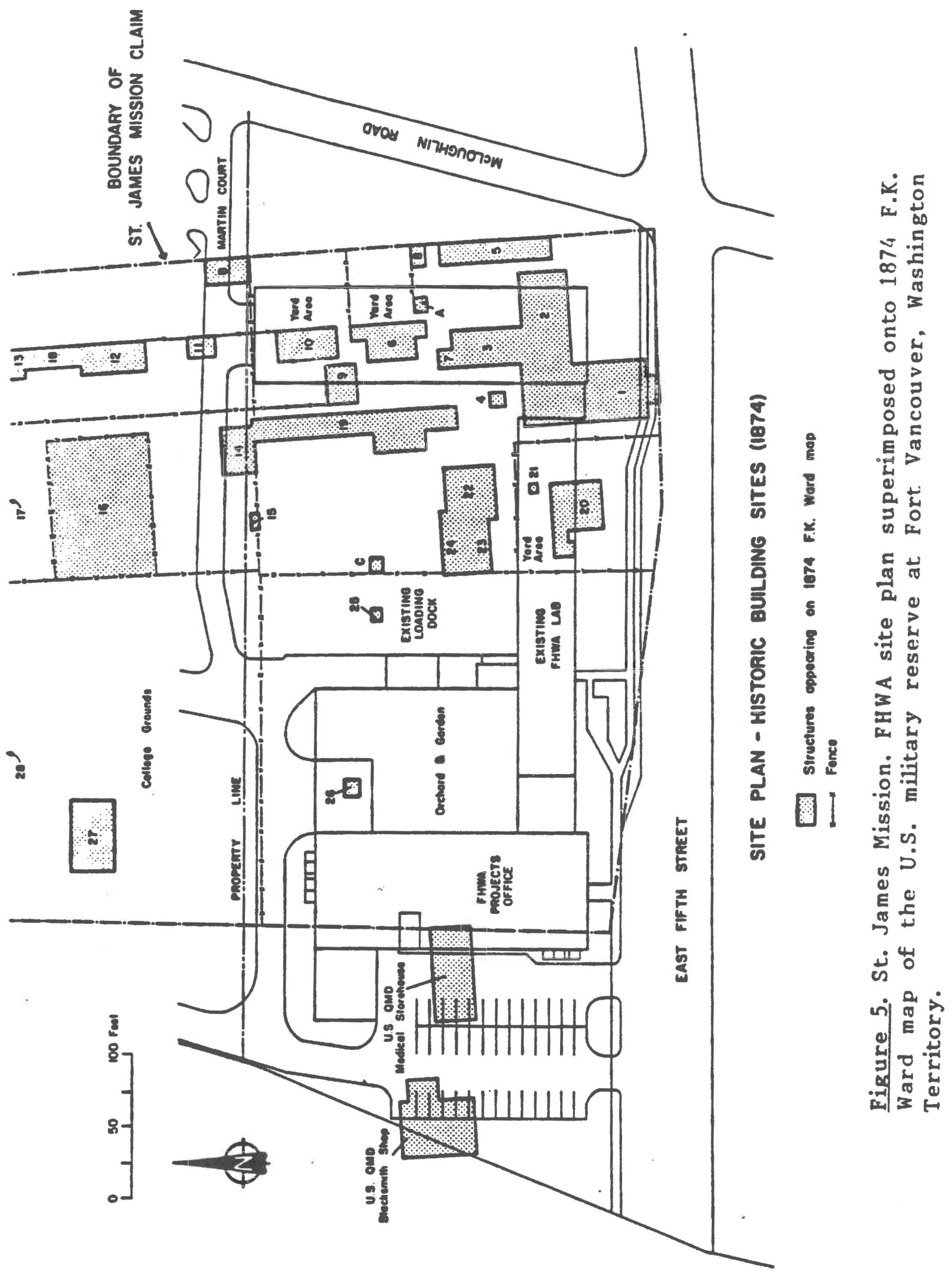




\begin{tabular}{|c|c|c|}
\hline Number & Property & $\begin{array}{l}\text { Dimensions } \\
\text { (in Feet) }\end{array}$ \\
\hline 1 & Church & $70 \times 46$ \\
\hline 2 & Convent & $73 \times 36$ \\
\hline 3 & Kitchen & $40 \times 28$ \\
\hline 4 & Waterworks & $10 \times 10$ \\
\hline 5 & Factories & $81 \times 11$ \\
\hline 6 & Old Ladies' Asylum & $30 \times 24$ \\
\hline 7 & Shoemaker's Shop & $16 \times 12$ \\
\hline 8 & Storehouse & $9 \times 9$ \\
\hline 9 & Laundry & $24 \times 26$ \\
\hline 10 & Female Orphan's Asylum & $45 \times 20$ \\
\hline 11 & Storehouse & $20 \times 16$ \\
\hline 12 & Male Orphan's Asylum & $40 \times 26$ \\
\hline 13 & Asylum and Bakery & $40 \times 24$ \\
\hline 14 & Stable & $30 \times 20$ \\
\hline 15 & Stable & $6 \times 11$ \\
\hline 16 & Pig sty & $24 \times 10$ \\
\hline 17 & Cow Stable & $100 \times 12$ \\
\hline 18 & Gallery & $36 \times 24$ \\
\hline 19 & Woodshed & $125 \times 12$ \\
\hline 20 & Bishop's House & $32 \times 24$ \\
\hline 21 & Bath House & $10 \times 10$ \\
\hline 22 & Priest's Residence & $36 \times 24$ \\
\hline 23 & Public Library & $36 \times 20$ \\
\hline 24 & Carpenter's shop & $26 \times 15$ \\
\hline 25 & Smokehouse & $9 \times 9$ \\
\hline 26 & Oratory & $12 \times 12$ \\
\hline 27 & College & $50 \times 30$ \\
\hline \multirow[t]{6}{*}{28} & Woodshop & $50 \times 12$ \\
\hline & Orchard and garden & \multirow[t]{5}{*}{ 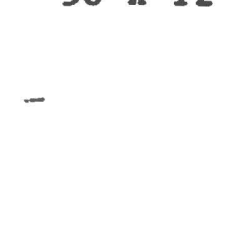 } \\
\hline & College grounds & \\
\hline & Bishop's House yard & \\
\hline & Old Ladies' A'sylum yard & \\
\hline & Female Orphan's Asylum yard & \\
\hline
\end{tabular}

Pigure 6. Key to St. James Mission Map. Adapted from 1872 Levi Farnsworth, Diagram of Survey of St. James Mission Claim, and Hussey 1957: Plate XXVI. 


\section{HEALTH CARE}

Home Visits

In addition to their work with the young and the old of the frontier community in Vancouver, the Sisters of Providence initiated a program which in no small way determined their future direction in the Pacific Northwest. Sister Joseph wrote: "We have the consolation of visiting the sick from time to time. We are happy to profit by such occasion whenever we can. The Protestants receive us cordially, and they are the predominating element in Vancouver."17 Thus began the Sisters' enterprise in community health care. Through this work, they ministered to the sick of the region regardless of religious denomination. During the 1860s, the Sisters averaged around 167 yearly visits to local area homes. The first few years of the 1870 s witnessed a dramatic rise in the number of such visits, which dropped off mid-decade only to peak and fall again by the end of the ten year period. During this decade, the sisters averaged 560 yearly visits to the sick of the community. The first half of the 1880 s also witnessed a sharp rise in the number of visits, which averaged 953 yearly for this period. Undoubtedly the increasing number of sisters in residence at the mission contributed to this upward trend of community service. 18

17 McCrosson, The Bell and The River, p. 129.

${ }^{18}$ In 1860 there were nine sisters, in 1870 there were 35 and by 1880, 63 sisters resided at the House of Providence. Source: "Chronicles of the Provincial House" 


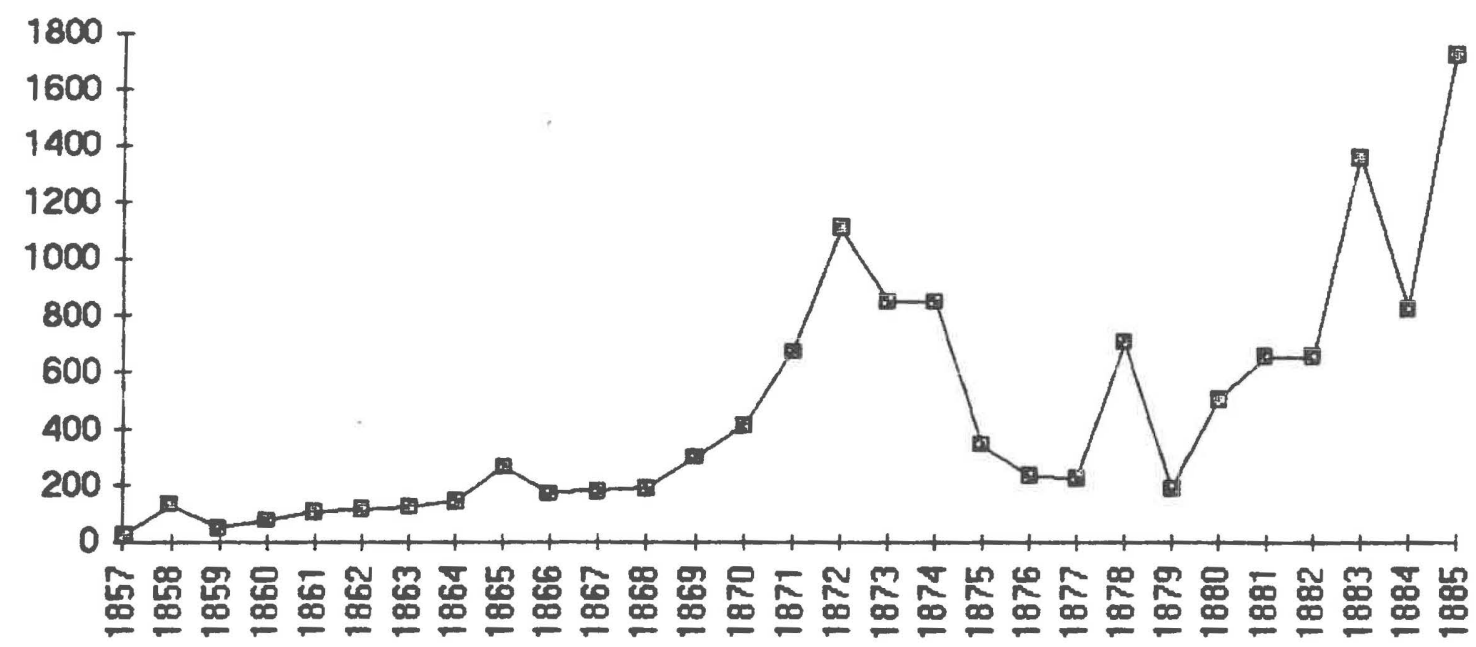

Figure 7. Home visits to the sick.

While making the "sick rounds" in the community, the Sisters did not exclude homes based on either social class or religious prejudices. A sampling taken from the "Register of Outpatients" ledger for the years 1868,1869 , and 1870 revealed an average of $26 \%$ of their visits were to non-Catholic homes, while in 1868 the percentage of visits to non-Catholics was almost $40 \%$. The religious denominations listed included Jewish, Methodist, other Protestant sects, and of course the nonspecific designation of "infidel." In addition to disregarding religious affiliation, the sisters visited a range of professional people. For example, the Register showed that washing women, servants and clerks were listed alongside doctors, captains and lawyers. 19

19"Register of Outpatients" MSS 22 (Seattle: Sisters of Providence Archives) 
The Founding of St. Joseph Hospital

Local support for the foundation of a hospital grew as a direct response to the Sisters' community work with the sick. This undertaking required more than just the determination or dedication of the Sisters. The Vancouver Ladies of Charity was organized to help initiate this institution. On April 6, 1858, more than half of the twenty-nine original members attended the inaugural meeting. While the majority of members were Catholics, Protestants and Jews were both included in the organization. In an astute move designed to gain wider community support, the group elected a Protestant as its first president. 20 The committee selected "St. Joseph Hospital" as the new institution's name.

Larger obstacles were not as easily addressed. The new hospital had neither a physical facility nor reliable funding. Regarding the former, Sister Joseph offered half of a recently completed building on the mission grounds to serve as a hospital. The $16^{\prime}$ by $20^{\prime}$ structure now housed both the new infirmary and the new bakery. The Ladies of Charity agreed to fund and install four beds and some chairs and tables in the hospital. Additionally, the group agreed to meet every two weeks in order to sew for the hospital. To finance care for the local area poor, each member pledged to contribute $121 / 2$ cents a week and to solicit funds from the community at large. For each charity patient sent to St. Joseph

${ }^{20}$ Dorothy Lenz, tr. "Chronicles of St. Joseph Hospital" MSS 22 (Seattle: Sisters of Providence Archives), p. 2. 
Hospital by their president, the Ladies of Charity agreed to pay the sisters $\$ 1.00$ per day. 21

Opening day June 7, 1858 was a watershed event for the Sisters of Providence in the Pacific Northwest. "In our humble little mission a sublime work was beginning, a future of heavenly favors lay ahead... This little corner of the world unknown to the great of the world, would later be the salvation of the infirmed, the consolation of the afflicted." 22

\section{Patients and Hospital Growth}

The genesis of St. Joseph Hospital was modest, and for varied reasons, its facilities were not expanded for almost a decade. The original building housed four beds in the male partition and three for female patients. 23 Throughout the 1860s, the average number of patients treated annually at St. Joseph Hospital was thirty-nine. 24 In 1866, St. Joseph Hospital moved to a larger facility on property owned by the Sisters. The hospital made additions in 1868,1870 , and 1872. The larger building helped to increase to ninety-nine, the average number of patients treated annually during the 1870 s.25 However, two significant factors negatively affected hospital growth

${ }^{21}$ Lenz, "Chronicles of St. Joseph Hospital", p. 3.

${ }^{22}$ Lenz, "Chronicles of St. Joseph Hospital", p. 3.

${ }^{23}$ Lenz, "Chronicles of St. Joseph Hospital", p. 3.

24"Patient Regișter, St. Joseph Hospital." MSS 22 (Seattle: Sisters of Providence Archives).

25 "Patient Register" MSS 22. 
during this period. In 1875, across the river in Portland, two new hospitals opened. The Sisters of Providence themselves founded one of these institutions. 26 Competition for patients, even among the Catholic hospitals, was noted. The Sisters at St. Joseph noted that "There were few patients this year...for they now went to [the] Portland hospital, newly opened."27

Another development that affected ongoing operations at St. Joseph Hospital was its destruction by fire on September 1, 1878. In an immediate show of community support, the citizens of Vancouver took up a collection that contributed $\$ 1,000$ toward new construction. 28 Work to rebuild the facility was undertaken almost immediately (it reopened less than seven months later on March 24, 1879) and that same year, the number of patients received for treatment was 124.29

The Sisters were zealous missionaries, deeply committed to their religion, who worked toward the conversion of community members. They used their contact with the local community, via the assorted asylums, and their personal influence to press their case. Their records are filled with stories of conversions, baptisms and

260lof Larsell. The Doctor in Oregon. (Portland, OR: Binfords and Mort, 1947), pp. 513-15. St. Vincent and Good Samaritan both opened in 1875.

${ }^{27}$ Lenz, "Chronicles of St. Joseph Hospital" p. 21.

${ }^{28}$ Lenz, "Chronicles of St. Joseph Hospital", p. 23.

${ }^{29}$ Patient Register" NSS 22. Further discussion of the patient population is found in chapter 7 . 
those poor lost souls who refused the righteous path. "No poor person was turned away. We always found a place in the humble and narrow shelter. Often ungrateful Protestants or bad Catholics were kept month after month without a cent paid, for the sole purpose of converting them or making them a little better." 30

The local community often utilized the social services provided by the Sisters. For example, between the summers of 1881 and 1885 , St. Joseph Hospital fulfilled a contract with Clark County for the care of poor patients at $\$ 4.50$ per week. 31 It is unclear why the contract was not renewed in 1885. However, the Sisters noted, "It is painful to see this class of society the object of the avarice of men who think only of making money without taking care of souls and without thinking of the loving care their state demands."32 Clearly, the implications were that a competitor underbid the Sisters and was thus awarded the contract by the county.

\section{Care of the Insane}

When the Sisters of Providence extended their services to include care for the mentally ill, they not only answered local area needs, but followed the example of their founding organization in Montreal.33 In 1861 a local newspaper reported:

${ }^{30}$ Lenz, "Chronicles of St. Joseph Hospital", p.8.

${ }^{31}$ Lenz, "Chronicles of St. Joseph Hospital", p.31.

${ }^{32}$ Lenz, "Chronicles of St. Joseph Hospital", p.28.

${ }^{33}$ McCrosson, The Bell and The River, p. 175. 
The Sisters of Charity have kindly taken care of the poor insane woman who has been for months confined in the county jail. The absence of an insane asylum in Oregon or the Washington Territory is seriously felt and should earnestly engage the attention of the next Legislature. We understand that the Sisters are willing to provide for the insane and secure for them good medical treatment if a barely sufficient remuneration be guaranteed by law. 34

From the very beginning, the Sisters had community advocates who supported their expansion into the mental health arena. In 1861, Sister Joseph contracted with the Washington Territorial Government to care for the insane. In exchange for services and accommodations to the mentally ill, the sisters would receive $\$ 8.00$ per week per patient to cover their expenses. This institution, the first insane asylum in the Pacific Northwest, became known as St. John's Lunatic Asylum. The inmates were originally housed on mission property, but after securing the contract from the Territorial Government, the Sisters refurbished an outbuilding on nearby land to house the insane. 35

The Sisters had reason to believe that the Territorial Government found their care facilities satisfactory. Governor William Pickering visited the institution and was apparently "kindly disposed in our regard."36 The Sisters record that, "The Government representatives made many unannounced visits and each of their

${ }^{34}$ Vancouver Chronicle 13 June $18612: 2$.

35 "Chronicles of the Provincial House" p. 152.

$36 \mathrm{John}$ Brougher. "Pioneer Medicine in Clarke County, Washington" Reprint from original in Northwest Medicine 1958, p. 3. 
reports were most praiseworthy and favorable." 37 However, monetary issues arose between the contracting parties. During the initial contract negotiations in 1861 with the Washington Territorial Government, Sister Joseph had voiced concerns over the wartime appearance of paper money, the infamous "greenbacks." She had attempted to secure a clause in the contract which guaranteed payment in coin. Her legal counsel persuaded the sister that "such a clause was not advisable nor acceptable" and that the sisters had nothing to fear regarding full payment. 38

The unhappiness began when the Territorial Government issued payment to the sisters in greenbacks, which unfortunately had lost $40 \%$ to $60 \%$ of their original value. Sister Joseph's immediate response was to bill the Territorial Government for the differences in the monetary exchange. By the end of the contractual period in 1865, she maintained that the government owed the House of Providence $\$ 4,000$. Under these circumstances, contract renegotiations between the two parties were less than ideal. In the end, the sisters lost the contract to care for the insane who were eventually moved to Monticello (present day Longview) in July 1866.39

Further Ramifications for Sister Joseph. Sister Joseph was an outspoken, strong individual unafraid to take unpopular stands. Her rancorous dealings with the Territorial Government are just one

37 "Chronicles of the Provincial House", p. 152.

38"Chronicles of the Provincial House", p. 152.

${ }^{39}$ Vancouver Register 21 July 1866 4:2. 
example. She was not one given to passive emotions. Her intense personality and determination had on many occasions been commented on by both peers and superiors alike. For example, her vision for the operation of the mission was perhaps a little more innovative than the other sisters would have liked. Sister Joseph herself noted in correspondence with the Mother House that "the two older sisters are not always ready to accept this view, and I sometimes must oppose their thinking. I do not believe that we can wait for those works to be organized as they are in the East in communities of long standing." 40

Sister Joseph's leadership skills apparently lacked the critical element of political tact, a crucial aspect of successful interpersonal relations. As one religious superior noted:

Sister Joseph is very pious, zealous, and all afire for the good works of Providence...[but] she is also too hasty. She is censured for not giving correction prudently. She offends by making reprimands at unfavorable times. Her manner opens a wound anew instead of healing it. Thus she makes her sisters suffer, though I am sure her intentions are very good.41

Thus, while no one doubted her sincerity and piety, Sister Joseph faced criticism in her leadership role.

In December 1866, Nother Philomene from the Sisters of Providence Mother House in Montreal, arrived in Vancouver to tour the western mission establishment. During her visit, she announced

\footnotetext{
$40 \mathrm{McCrosson}$, The Bell and The River, p. 151.

41 McCrosson, The Bell and The River, p. 173.
} 
that another sister had been appointed to succeed Sister Joseph as leader of the Providence community in Vancouver. Now relieved of the top administrative role, Sister Joseph was appointed bursar for the western missions. 42 It is unclear whether internal discord or the difficulties with the Washington Territorial government in any way led to her demotion. Yet the timing does suggest some association.

The last word between the government and the sisters over the care of the insane had yet to be heard. After some influential members of the community interceded on the behalf of the Sisters, the Territorial Government passed a bill on January 26, 1867 which granted them $\$ 4,000$ plus interest. 43

\section{FINANCING THE OPERATIONS}

The Sisters of Providence relied on a number of methods to raise funds for the financial support of their institutions. As discussed earlier, in the cases of care for the insane and the county poor, they contracted with the government agencies. The hospital charged $\$ 1.00$ per day to paying patients and received additional funding through the efforts of the Ladies of Charity. The Orphan Asylum Association of Oregon and Washington Territory was organized March 5, 1860 to support orphans at the mission. These organizations accepted outright donations and collected fees and

\footnotetext{
42 McCrosson, The Bell and The River, p. 202.

43"Chronicles of the Provincial House", p. 152.
} 
subscriptions from community members which assisted the financial operations for the social institutions of the House of Providence.

In addition to community efforts toward their financial wellbeing, the Sisters solicited direct funding as well. They undertook adventurous journeys to the mining areas of Idaho and Montana in order to solicit donations in support of mission activities. Additionally, the garrison at Fort Vancouver was subject to a monthly collection by the Sisters. 44

Providence Academy collected (in advance) tuition and fees from the boarding and day pupils. Records of payment indicate that payment in kind as well as in cash was accepted by the Sisters. 45 The Sisters also sponsored bazaars or 'Orphan's Pairs' in order to make ends meet. Thus, whether directly or indirectly, the community played a significant role in financing the continued operations of the Sisters. A local paper noted:

One of the great events of the year in this burg is announced for next week, the fair for the benefit of the orphan asylum, the only institution of its kind north of San Francisco. It has always been liberally patronized by the citizens of Vancouver irrespective of creed, as it should be, and we trust will receive this year the support that such a worthy charity and benevolence deserves. 46

${ }^{44}$ McCrosson, The Bell and The River, p. 229.

45"Boarders' Accounts", Providence of the Holy Angels 18571889, MSS 22 (Seattle: Sisters of Providence Archives)

${ }^{46}$ Vancouver Independent 14 Nov 1878 2:2. 
Such neighborhood support for the House of Providence extended beyond economic needs into the realm of community pride. After airing initial doubts about the academy for girls, the community came to view the school as a beneficial addition to the cultural and moral character of Vancouver. When expansion plans for the House of Providence were announced, a local newspaper editor wrote:

\begin{abstract}
We think the improvements in the Education establishments in our town will prove greatly beneficial. For our part, we would sooner see a few first-class schools or Academies established here than all the Territorial Capitals and penitentiaries. The former not only tend to improve the moral tone of society but also bring to us a desirable class of population who are in affluent circumstances and are anxious to have their children properly educated. 47
\end{abstract}

The Sisters of Providence arrived in the Pacific Northwest with a mission to relieve the destitute and suffering humanity of the region. They founded asylums for the aged, the sick and the orphans, all of which answered community needs not addressed by other groups. They brought kindness and assistance to a harsh environment. The community responded in many ways, not the least of which was financial assistance and moral support for the works of the House of Providence. The mission became not only a part of the community, but reflected the community on the American frontier.

${ }^{47}$ Vancouver Register 9 March $18673: 1$. 
CHAPTER IV

\section{MEDICAL PRACTICE IN THE NINETEENTH CENTURY}

In the nineteenth century, Americans had many medical choices but few effective therapies to choose from. At best, the world of medicine was problematic for physicians. Often it was dangerous for patients. Medical practitioners operated from a body of knowledge that dated from Ancient Greece and had changed little in two millennia. But the impetus of the Enlightenment's emphasis upon rational thought touched the practice of medicine. The Paris Clinical School affected the attitude towards, and the investigation of, disease. Whereas the traditional view held that sickness was a general state of being, the new French outlook postulated that diseases were specific in nature, with a common set of symptoms and a predictable course of action. Clinical material and autopsies became the accepted means for achieving professional recognition. The hospital as an institution became a central development of these changes. 1 Before the Civil War, despite the language barrier, a considerable number of Americans traveled to France and studied medicine. However, upon their return, only the "privileged and ambitious" acquired hospital or teaching positions from which to

${ }^{1}$ Charles E. Rosenberg, The Care of Strangers (New York: Basic Books, Inc., Publishers, 1987), pp. 82-83. 
train the next generation of American physicians. ${ }^{2}$ Thus, change within the United States medical profession was slow and uninspired. There were many long-standing therapeutic obstacles which, in no small way, retarded the development of a truly sound medical knowledge in the nineteenth century. Common practices such as blood letting and polypharmacy had a generation of adherents influencing medical practices in the United States. Quack doctors and miracle cures flourished in an unregulated environment. The failure of materia medica and physicians' use of calomel, opium and arsenic gave rise to splinter medical practices such as electropathy, hydropathy and transcendental medicine. These medical "heresies" rivaled religious sects, political parties and other movements and fads, but unfortunately did little to correct past errors. Mainstream physicians were "dispensers of pills, potions and bandages," caught between the nature of medicine as an art and as a science. Medical schools were regionally inspired, lacking a nationally established curriculum and in many cases a hospital affiliation. The post-Civil War era witnessed the rise of the hospital as an institution, and medical school reform. Late in the century, the widening acceptance of the germ theory established a scientific basis for the practice of medicine.

Nineteenth century medical knowledge and practices existed in a state of flux. Lacking a scientific foundation and understanding of the relationship between sanitation and the nature of disease,

\footnotetext{
${ }^{2}$ Rosenberg, The Care of Strangers, p. 86.
} 
practitioners of many schools of thought prescribed remedies designed to at least create a change in the physical state of the patient. The general public, constantly searching for relief from a range of dread afflictions, accepted almost any remedy which produced some change in condition. ${ }^{3}$

As an occupational group, orthodox or allopathic physicians practiced medicine designated as the medical mainstream; they were generally well-educated and well-read physicians. Medical and scientific discoveries influenced the practice of nineteenth century medicine, but changes were slow and often resisted. The body of medical knowledge used by physicians at any given time was often directly affected by the economic interests of physicians in earning a livelihood. The competition between "mainstream" medicine and "fringe practices" (patent medicines and a variety of "-pathy" schools) resulted in orthodox physicians adopting therapies which produced consistent results, thereby providing patients some results for fees rendered. Patient demand for active therapy against a background of endemic and epidemic diseases reinforced the dispersing of drug remedies. Medical advice which promoted health concepts such as diet and exercise were secondary remedies, usually advocated by "fringe" groups. The medical environment in the nineteenth century must be understood in terms of persistence in treatments (whether harmful or helpful), the economic competition

3 John S. Haller Jr. American Medicine in Transition, $1840-$ 1910. (Urbana: University of Tllinois Press, 1981), pp. viii-xi. 
among various medical practitioners, and the public demand for active treatment to alleviate their ills. ${ }^{4}$

The printing press was a critical factor in promulgating changing health attitudes. It was used to propagate medical literature and to promote many kinds of patent medicines. Authors advocated not only their favorite solutions to medical conditions, but often addressed specific social and moral ills, giving much of the literature an almost evangelical tone.

\section{ORTHODOX MEDICINE}

Education of Regular Physicians

Medical education in the U.S. developed, for the most part, in the first half of the nineteenth century and was mixed in practice. The desire to become a doctor meant a minimum three year apprenticeship for which one paid a fee. There was neither organized medical reading nor actual practice; with the exception of the three year requirement, no general rules regulated the training of apprentices. 5 Medical education in America was unique in that it required the student to complete two terms of the same course material; $i$. e., the student took courses in the first term and then returned the next year and repeated the identical class work. 6 The

${ }^{4}$ William G. Rothstein, American Physicians in the Nineteenth Century. (Baltimore: The Johns Hopkins University Press, 1972), pp. 3-25.

${ }^{5}$ Henry B. Shafer, The American Medical Profession 1783 to 1850. (New York: AMS Press, 1936), pp. 33-34.

${ }^{6}$ Shafer, American Medical Profession, p. 35. 
courses included anatomy, physiology, surgery and a multifaceted course that covered midwife practices, diseases of women and children, materia medica, in addition to the theory, practice and legal aspects of medicine. After completing the first term, the student could receive a license which substituted for a Bachelor of Medicine degree. Many medical schools discontinued this practice because few who received it returned to complete the M.D. At the end of the second term, the candidate was examined by a professor or committee, presented and defended a thesis, and was awarded a degree. ${ }^{7}$ The new doctor now faced a commercial marketplace in which his skills were not always in demand.

During the era of overland migration, doctors (some with diplomas and others with little or no medical training) arrived in Oregon, took up land claims, and established practices. A significant number of physicians in the Pacific Northwest had apprenticed with some practitioner in the Middle West or the East, but had not graduated from a medical school. Many who used the title 'Dr.' were granted it only because they claimed medical knowledge. 8 The pioneers thus brought both their practitioners and their chronic conditions with them to Oregon.

${ }^{7}$ Shafer, American Medical Profession, pp. 74-78.

${ }^{8}$ olof Larsell, The Doctor in Oregon, (Portland, OR: Binfords and Mort, 1947), p. 151. 
Therapies of Regular Physicians - Heroic Medicine

Orthodox physicians were marked as such by their therapeutic practices. Termed "heroic medicine," these therapies were characterized by violent procedures, specifically bloodletting, and the use of purgatives and emetics. According to the medical theories of the era, active therapy, that which produced immediate reaction in the patient, was believed to be the most successful method of treatment. 9 These measures were symbolic of allopathic practice. They also demonstrated dramatic and swift changes in patients. Bleeding was deemed a viable treatment because consistent change was easily secured. Patients were "bled till symptoms of fainting came on."10 It was not uncommon to take twenty to thirty ounces of blood on one day and to repeat the process on the next. Many doctors urged the necessity of bleeding until unconsciousness.11 Patient loss-of-color and a weakened, rapid pulse were both visible manifestations of this active therapy.

Other characteristic therapies of orthodox physicians included measures to purify and cleanse the internal organs of digestion, specifically the bowels and stomach. Thus, physicians employed harsh drugs which implemented their "puke-and-purge" therapies, often in conjunction with bleeding. Emetic drugs such as tartar emetic,

${ }^{9}$ Carl J. Pfeiffer, The Art and Practice of Western Medicine in the Early Nineteenth Century. (Jefferson: McParland \& Company, Inc. Publishers, 1985), p. 10.

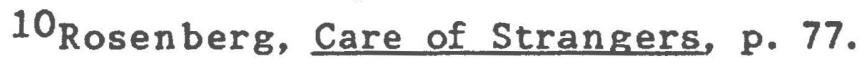

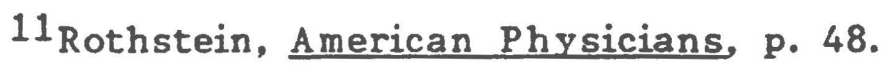


caused debilitating vomiting and were widely used by physicians. 12 Mercury-containing drugs such as calomel were widely prescribed as purgatives. During the nineteenth century, calomel was one of the prominent drugs of western physicians. 13 For many, it represented a universal cure. One contemporary doctor wrote that "when a practitioner was puzzled about the administration of any medicine in a disease, it was deemed perfectly proper for him to prescribe a dose of calomel."14

As a therapy, calomel had problems, not the least of which was its basic toxicity to human life. In the first stage of poisoning, purging and salivation occurred. In the second stage, the gums, tongue and salivary glands became sore, inflamed, and painful. If dosing continued, the results were disastrous. As one contemporary noted:

The mouth feels unusually hot...the gums are swollen, red, and tender; ulcers make their appearance and spread in all directions; the saliva is thick and stringy, and has that peculiar, offensive odor characteristic of mercurial disease. The tongue is swollen and stiff and there is some fever, with derangement of the secretions. The disease progressing, it destroys every part that it touches, until the lips, the cheeks, and even the bones have been eaten away before death comes to the sufferer's relief. 15

12 John Harley Warner, "Power, Conflict and Identity in MidNineteenth Century American Medicine: Therapeutic Change at the Commercial Hospital in Cincinnati" The Journal of American History. (Narch 1987), p. 937.

13 Haller, American Medicine in Transition, p. 85.

${ }^{14}$ Rothstein, American Physicians, p. 48.

${ }^{15}$ Rothstein, American Physicians, P. 51. 
These results came from repeated large doses. Because minerals have a tendency to remain in the system, the effects of calomel was cumulative. Although physicians recognized the terrible side-effects of calomel therapy, they continued to give it in large doses. 16

Puke-and-purge therapies should be understood in their proper historical context; i. e., as harsh and extremely fast-acting measures. As one physician wrote, "if vomited, they did not come up in gentle puffs and gusts, but the action was cyclonic. If, perchance, the stomach was passed the expulsion would be by the rectum and anus, and this would be equal to a regular oil-well gusher." 17

Quinine and Opium. Orthodox physicians continued to expand their pharmacological resources throughout the nineteenth century while retaining the belief that the best therapeutic remedy made a demonstrable effect upon the patient. 18 Two notable drugs, one an antipyretic (a drug that reduces fever) and the other an analgesic (a drug that relieves pain) grew in popularity for doctors of this era.

Quinine, a derivative of cinchona bark, had been commercially, although not largely, available beginning in the 1820s. Its effective protection against the dreaded "fever and ague" promoted widespread demand for the drug. Quinine was one of the few

\footnotetext{
${ }^{16}$ Rothstein, American Physicians, P. 51.

${ }^{17}$ Rothstein, American Physicians, p. 49.

${ }^{18}$ Rothstein, American Physicians, p. 186.
} 
effective treatments in the allopaths' arsenal of drugs. As such, physicians used it to treat an ever-growing assortment of ills. By the 1880 s, quinine came to replace calomel as the "cure-all" drug of choice among orthodox physicians. Like calomel, it was overused by doctors to the point of severely affecting the health of the people it was supposed to be helping. 19 In moderate doses, quinine weakened the heart and pulse causing gastric irritation along with nervousness and giddiness. These side effects were intensified by frequent doses of drug. In large doses, quinine produced a set of symptoms which became so common that they themselves were identified specifically by the term 'cinchonism,' which was characterized by ringing of the ears and in severe cases, deafness and blindness. 20

Opium and its extract morphine were the most significant painrelieving drugs used by doctors. One physician wrote "opium is the most conspicuous article in the pharmacopoeia. Its extraordinary efficacy in relieving pain, the versatility of its powers, and its reliability in emergencies, give it a preeminent standing." 21 Because opium was an effective therapeutic treatment for pain relief, physicians used it in treating just about every illness. Its popularity as the drug of choice prescribed by doctors continued to

${ }^{19}$ Rothstein, American Physicians, pp. 188-189.

20 Rothstein, American Physicians, p. 189.

21 J.F.A. Adams, "Substitutes for Opium in Chronic Diseases" Boston Medical and Surgical Journal 121 (1889): 351 quoted in Rothstein, American Physicians, p. 191. 
grow throughout the century despite the overwhelming evidence of its addictive nature. 22

How to Measure Success. During the nineteenth century, a physician's medical practice was judged to be successful if an adequate number of patients provided the doctor a comfortable livelihood. In rural areas, achieving complete economic independence was more difficult than in the cities. The physician often had other business interests to supplement her or his practice. Frequently, payment for medical services was in kind rather than in cash. The account books of one Oregon physician in the 1850 s listed wood, coal and venison given in lieu of coin. 23 To attract clients, a physician had to demonstrate an ability to achieve consistent results in a variety of 'specialties.' Not only did they examine and prescribe for patients, they pulled teeth, amputated limbs and filled prescriptions. Surgery was done in the home without benefit of anesthesia or antiseptic techniques. Thus, the skill of the surgeon rested upon his speed.24 The pharmacy was another major part of a successful practice. The most common entry in many physician account books read "Med. \& Advice $\$ 3.00 "$ or "Geo. Miller Baby - $2 \mathrm{Rx} \$ 1.50 . " 25$ One

22Rothstein, American Physicians, p. 191.

23 MSS 1116, Account Book of Justin Millard 1853-1855. Portland, OR. The Oregon Historical Society.

${ }^{24}$ Prederick C. Waite, "Medical Education of Dr. Whitman." Oregon Historical Quarterly. (September 1936), pp. 192-216.

25 MSS 1116, Account Book of Justin Millard 1853-1855. MSS 194 Linklater Collection, Portland, OR. Washington County Historical Society. 
contemporary recalled, "A doctor who could do all his 'ride' with one horse could not be very busy and the inference was he was not very capable. Such a one was called a 'one-horse doctor', a term of deprecation."26

Physicians felt an urgency to demonstrate an effect upon their patients. Given the multitude of options available to the medical consumer, doctors were compelled to provide services which consistently provided the patients some sense that they got their money's worth. Often physicians were consulted only when the patient had determined that their medical needs exceeded their own self-help abilities. Patients wanted results, not only relief from their ills, but an equitable fiscal exchange with the doctor. 27 Physicians, very much aware of this attitude, responded in ways that promoted their practice. Doctors were more than willing to adopt successful practices such as vaccination even though they could not explain the mechanism at work.28 Physicians also felt pressured to give the patient something (such as placebos) which provided some sense of relief. One doctor wrote, "When people were not sick or they thought they were, I had to give then something...you can't do anything for them, but they are still your patients, and you have to do something...we used to have standard prescriptions that we used in

26 Waite, "Medical Education of Dr. Whitman", p. 208.

${ }^{27}$ Rothstein, American Physicians, pp. 12-13.

28 MSS 1037 Letters of Alden H. Steele, 1823 - 1902 Portland, OR. The Oregon Historical Society. See also Rothstein, American Physicians, p. 13. 
such cases." 29 Doctors were often identified by the drugs they prescribed. Recalled one pioneer, "he was what was known in those days as a calomel and quinine doctor, as that is what he prescribed for everything that ailed people."30 In rural areas, patients could not always get the personal service of a physician when they wanted or required it. Often times the doctors used the mail to diagnose, prescribe or otherwise treat their patients. 31

\section{ALTERNATIVE THERAPIES}

The failure of orthodox medical therapies to effectively cure their patients had several ramifications. Allopathic physicians lost public esteem and trust. Patients resisted the harsh treatment synonymous with heroic therapies. Seizing the opportunity, competitive medical sects effectively organized and promoted alternative therapies. All 'irregular' sects eventually met with strong opposition from the allopathic community.

\section{Thomsonianism}

One such movement, Thomsonianism was the source of significant irritation for the regular medical profession during the

${ }^{29}$ Harry Cliff, "Medical Economics Lecture" Lecture presented at Oregon Health Sciences University, Portland, OR May 13, 1936.

30 Fred Lockley, "Recollections of Benj. Franklin Bonney" Oregon Historical Quarterly (24 March 1923), p. 54.

${ }^{31}$ MSS 1037 Steele Collection, OHS. MSS 822 Letters, bills and receipts of G.S. Cozad. Portland, OR. The Oregon Historical Society. 
first half of the nineteenth century. 32 Samuel Thomson (1769-1843) developed a therapeutic system based on "a vague misunderstanding of Greek theories" which relied "largely upon steambaths and botanical remedies." 33 He denounced heroic medical practices and thus incurred the wrath of traditional physicians. In 1822, Thomson published his methods and botanical cures in a work entitled New Guide to Health. The book gave life to a political and social movement that championed the cause of the common man. Thomsonians sought not only association with popular democracy, but to be identified with its leader, Andrew Jackson. 34

Thomsonianism received considerable patronage in the Northeast, especially in Massachusetts, Vermont and New Hampshire. It was also widely practiced in the South (most notably Mississippi) and had a significant following in ohio. 35 Many adherents to the unregulated movement professed certain fundamental but dualistic beliefs. They claimed a historical tradition of both revolution (wresting medicine from the doctors) and reformation (securing rights for the common man) as integral parts of the movement. 36

${ }^{32}$ Rothstein, American Physicians, p. 125.

33 John Duffy, The Healers, (New York: McGraw-Hill Book Company, 1976), p. 110.

${ }^{34}$ Duffy, The Healers, p. 111. Joseph Kett, The Formation of the American Medical Profession, (New Haven: Yale University Press, 1968), p. 110.

${ }^{35}$ Kett, Formation of American Medical Profession, p. 106.

${ }^{36} \mathrm{Kett}$, Formation of American Medical Profession, p. 108. 
The Thomsonians associated themselves with a number of social movements during the 1830 s such as those directed against alcohol, tobacco and coffee. 37 Additionally, their movement was the major political force behind the repeal of medical licensing laws. ${ }^{38}$ Thus, Thomsonianism was a backlash against an educated and privileged medical class which failed to secure positive results for those in need of help.

\section{Homeopathy}

Another system of medical knowledge that presented a significant challenge to orthodox medical practices was homeopathy, a German import introduced into the United States in the mid-1820s. Homeopathic theory was developed by Samuel Christian Hahnemann (1755-1843), a well-educated scholar who studied medicine in both Leipzig and Vienna. ${ }^{39}$ After graduation, Hahnemann engaged in a number of pursuits on the Continent. During this time, he experimented and wrote on health issues. Like others, Hahnemann criticized the orthodox medical practices of bleeding and excessive drugging and dosing of patients. He initiated experiments with different drugs that eventually lead to two fundamental beliefs of homeopathic practice: like cures like; i. e., a drug that induces the condition in a healthy person will cure that illness for a sick one,

${ }^{37}$ Duffy, The Healers, p. 112.

${ }^{38}$ Rothstein, American Physicians, p. 125.

${ }^{39}$ Duffy, The Healers, p. 112. 
and the value of tiny doses.40 In conjunction with a common sense approach to daily life such as personal hygiene, moderate exercise, a good diet, and fresh air, homeopathic practices had much to offer over the depletive practices of the allopathic practitioner.

Unlike the Thomsonians who found the bulk of their supporters among the "frontier types" of lesser means, homeopathic physicians attracted their clientele from the urban upper middle class and the wealthy. 41 Homeopaths like allopaths, believed strongly in the education of its practitioners. 42

Homeopathy was well received for many reasons, not the least of which was the inability of orthodox medicine to successfully address the cholera epidemics of the 1830 s and 1840 s. 43 Additionally, homeopathy was "extremely fashionable among Europeans nobility and upper classes" who were often emulated by rich Americans. 44 Thus, a potential wealthy clientele no doubt attracted many doctors to either switching from an allopathic practice or training outright as a homeopathic physician.

Orthodox medicine initially reserved judgment upon homeopathic practices. However, by the late 1830 s that situation had changed. Throughout the 1840s (especially after the formation of the

${ }^{40}$ Duffy, The Healers, p. 113. Rothstein, American Physicians, pp. 152-153.

${ }^{41}$ Rothstein, American Physicians, p. 160.

${ }^{42}$ Duffy, The Healers, p. 115.

${ }^{43} \mathrm{Kett}$, Formation of American Medical Profession, p. 138.

${ }^{44}$ Rothstein, American Physicians, p. 160. 
American Medical Association in 1847) the battle lines between the allopathic and the homeopathic doctors became more sharply defined.45 The orthodox physicians waged a fairly successful campaign against homeopathy. For example, homeopathic doctors were denied admission into the Army Medical Corp at the outbreak of the Civil War. 46 Additionally, during the third quarter of the nineteenth century, homeopaths were generally denied positions at major hospitals around the U.S. In response, they founded their own competing institutions, many of which were highly successful. 47

\section{Eclecticism}

After 1840 the Thomsonian movement declined, splintered, reformed, reorganized and re-emerged as neo-Thomsonianism and a number of other botanical factions. The rise of Eclecticism was facilitated by the splintering of the Thomsonian movement but it did not replace it as such. 48

Wooster Beach (1764-1868), founder of the Eclectic movement, had himself received a self-styled eclectic medical education. Beach had graduated from an orthodox medical school. But like others before him, he came to criticize heroic medicine. He turned to botanical doctors, Thomsonians, Native American practices and others

${ }^{45}$ Duffy, The Healers, p. 117.

${ }^{46}$ Duffy, The Healers, p. 118.

47 Duffy, The Healers, p. 118.

${ }^{48}$ Rothstein, American Physicians, p. 217. 
in search of effective therapies. Thus, the term "eclectic" referred to the practitioner's willingness to adapt 'proven' techniques, even resorting to orthodox medical practices upon occasion. 49 For the most part, the public associated eclectic practice with botanical cures.

Like the homeopathic movement, the Eclectics founded schools, issued degrees and published journals. But of the three major medical rivals of the mid-nineteenth century (homeopathy, eclecticism, allopathy), the Eclectics were clearly the smallest group. They were best represented in the Midwestern states. Eclectic physicians tended to practice in villages or small towns (often as the only doctor), which promoted their movement among rural people. Their rural strength provided some political strength in battles against the orthodox medical community. 50

\section{Other Options}

The common denominator of almost every competing medical therapy was a disdain for the heroic measures of orthodox medicine. Besides those discussed, other health movements flourished as well. The cultural environment of the United States provided an atmosphere where 'evangelical' health reformers, such as sylvester Graham, were able to spread their gospel of moderation, clean living and a healthful diet. Movements such as hydropathy also received a 218.

${ }^{49}$ Duffy, The Healers, p. 114. Rothstein, American Physicians, p. 50 Rothstein, American Physicians, pp. 226-229. 
wide following in the U.S. But perhaps the biggest challenge that faced any medical practitioner was the business of self-help and the patent medicine industry that cashed in on such attitudes. Local newspapers in no small way contributed to the attitude that anyone who could read might treat themselves and their families. "Cure for Cholera" and "Diptheria" [sic] headed columns in which editors passed on 'beneficial' recipes ("so say those who have tried it") for their patrons. 51 spas and clinics advertised their claims for the "Permanent cure of all Private and Chronic Diseases." 52 If something so dramatic as self-institutionalization was not required, many ads advocated tonics and ointments, all of which claimed the product was effective, if not revolutionary, in the treatment of any and every problem. 53

Both the buyers and the sellers of patent medicines had complex and subtle motives for their actions. During the nineteenth century, everyone witnessed assorted minor ailments and major diseases, whether personally or through contact with family and friends. Self-help, with its "high-enough" percentage of success, helped to promote the patent medicine business. The alcohol and opium content of various patent medicines affected enough

$51_{\text {Anonymous "Cure for Cholera." Oregon Statesman, } 24}$ December 1866, 2:4. Editor. "Diphtheria Recipe." Oregon Statesman, 6 March 1865, 1:5.

52 Anonymous. "Advertisement." Oregon Statesman, 26 May $1862,3: 4$.

53Anonymous. "Advertisement." Oregon Statesman, 17 oct 1854, $3: 5$. 
physiological change and relief from ailments that at least this one requirement of the consuming public was satisfied. Yet, even those medicines containing inactive ingredients attracted legions of faithful users, demonstrating the desperate search for relief and a dedication to self-help methods. Americans were (and still are) impatient about illness, seeking immediate action and results and were "prone to taking things into their own hands."54

Self-help and the patent medicine business were significantly aided by the self-limiting nature of many illnesses. As one physician noted "If I didn't get back to look at a case or take care of it they got well, strange to say." 55 Thus, reputations for many medicines, doctors, and practices flourished, unrelated to their actual curative powers.

Another avenue of self-help was folk medicine, often part of the feminine domain. One of the many roles women played was that of nurse and healer for family and neighbors. A woman's garden often included medicinal herbs. Since professional help in no small way depended on weather and road conditions, home cures and the "old reliable remedies" were carefully prepared and generally perceived as successful. 56

54 James Harvey Young, "Patent Medicines and the Self-Help Syndrome." In Sickness and Health in America, Edited by Susan Reverby and David Rosner. (Madison: The University of Wisconsin Press, 1985). pp. 71-80.

\section{${ }^{55}$ Cliff "Medical Economics Lecture" 13 May 1936.}

${ }^{56}$ Harriet Nesmith McArthur "Recollections of the Rickreall" Oregon Historical Quarterly (December 1929): 362-383. 
RURAL PRACTICE

\section{Establishing a Practice}

Nineteenth century physicians were self-employed. Achieving and maintaining a successful practice meant that doctors needed paying patients. With numerous health care options available to Americans, the physician who owned a reputation for superior therapeutic results was more likely to be called upon. Evidence indicates that rural communities found it difficult to attract and keep good doctors. 57 Additionally, because both the doctor and the patient might be called on to travel, the preferred medical relief was not always immediately available. Emergencies most likely made or broke local physicians. For example, when Thomas Condon was forced to rely on two local physicians to treat his son's dislocated hip, the results were disastrous for all involved. The doctors' attempt to reset the hip lasted three torturous days, utilized violent means, inflicted great pain upon the patient, and failed to accomplish the intended result. 58 Needless to say, circumstances such as these clearly demonstrated incompetence and undoubtedly quickly circulated around the community. Those who failed to show some level of skill would not likely be patronized. Unfortunately, this ostracism usually occurred after some tragedy had occurred.

57 MSS 1037 Letters of Alden H. Steele, 1823 - 1902. Portland, OR. The Oregon Historical Society.

58 MSS 1037 Steele Collection. 
In rural Oregon, orthodox, homeopathic and eclectic physicians all practiced. In fact, the therapeutic measures of the pioneer physicians often crossed sectarian boundaries. Thus, both homeopathic and allopathic physicians occasionally adopted the successful practices of their counterparts, which tended to blur the differences among practitioners. ${ }^{59}$ Within the state of Oregon, the presence of non-orthodox practitioners is aptly illustrated by their own publications. In 1866, the first regional medical journal, the "Oregon Physio-Medical Journal" was published by a Thomsonian splinter group. 60

\section{Competition}

The proliferation of non-orthodox medical schools challenged the reign of the orthodox physicians. Additionally, the growing number of doctors with medical degrees made for too many providers and not enough patients, contributing to the difficulty in earning a livelihood.61 The identity and image of orthodox physicians was significantly threatened by competing medical sects. In some cases they responded by clinging steadfastly to heroic therapies.62 Generally, however, orthodox physicians responded to market place demands and sectarian criticism and began to reform their

${ }^{59}$ Larsell, The Doctor in Oregon, p. 409.

60 olof Larsell, "History of Medical Journals in the Pacific Northwest." Oregon Historical Quarterly (March 1946) p. 3.

$$
\begin{aligned}
& 61 \text { Warner, "Power, Conflict, and Identity" p. } 935 . \\
& 62 \text { Warner, "Power, Conflict, and Identity" p. } 939 .
\end{aligned}
$$


therapeutic practices. Thus, heroic bleeding, drugging and dosing declined steadily in the second half of the nineteenth century. 63 What remained the acid test for physicians of any sectarian calling, was their ability to achieve consistent, beneficial results in order to gather a sufficient client base that provided adequate financial means. 64

\section{HOSPITALS}

The Hospital as an Institution

Before the Civil War, the hospital was an insignificant institution in the health care realm. Its social structure mirrored the deferential and hierarchical society that supported it financially. Class lines between doctor and patient were rigid and never crossed. Doctors used the hospital, but they did not control it. Hospital therapies differed little from home care. 65 The hospital was a place for those who lacked the means and/or the ability to care for themselves. It housed "the insane, the blind and crippled, the aged, the alcoholic and syphilitic" as well as working-class sufferers of an assortment of ailments. Pew entered confinement voluntarily and the middle-class almost never utilized hospital facilities. 66 The patients,

\footnotetext{
${ }^{63}$ Rothstein, American Physicians, p. 181.

${ }^{64}$ Rothstein, American Physicians, p. 13.

${ }^{65}$ Rosenberg, The Care of Strangers, p. 5.

${ }^{66}$ Rosenberg, The Care of Strangers, p. 15.
} 
by and large, were poor and without roots in the community. 67 Destitution was a dilemma that Americans of that era met with mixed emotion. The "morality of being poor" left many supporting Christian aid for the "respectable poor" but opposed to helping criminals, prostitutes, drifters and immigrants who often had no alternative but a public hospital. 68

Hospitals were philanthropic institutions sponsored by the wealthy, who generally saw such activity as part of their social responsibility. Such stewardship was not without its benefits. Hospitals provided opportunities for well-to-do physicians who viewed their profession as more than just money-making operations. For these doctors, the hospital provided a familiar atmosphere of paternalism which confirmed their deep-seated class distinctions. 69

The admissions policies were generally governed by a board of lay administrators or trustees. These policies reinforced the social and moral values of the hospital donors. Admittance to the institution often required written testimony that praised the character and morality of the potential patient. In many cases, gaining admittance

${ }^{67}$ Morris J. Vogel, "The Transformation of the American Hospital, 1850 - 1920." in Health Care in America, Edited by Susan Reverby and David Rosner. (Philadelphia: Temple University Press, 1979), p. 105.

68 James H. Cassedy, American Medicine and Statistical Thinking, 1800 - 1860 (Cambridge: Harvard University Press, 1984), p. 28.

${ }^{69}$ Vogel, "Transformation of the American Hospital", p. 105. 
as a free patient necessitated the outright sponsorship of a donor. 70 Physicians played only a coordinating role in patient admissions. As hospitals professionalized, medical reasons superseded other considerations in admission policies. Thus, over time, the doctor gained some control over policy but was still constrained by the number of free beds available at the hospital. 71

Hospital practitioners in eastern cities were considered the medical elite, those who through their work contributed to the development of the profession, not merely its practice. For most of the century, hospital physicians were not remunerated by either the institution or the patient. However, hospital work allowed the physician access to a wider variety of medical problems, many of which were not often seen in private practice. Thus, a successful hospital career paid off when the doctor's reputation landed him well-to-do patients in his personal practice. ${ }^{72}$

A movement to expand and improve hospitals began in the 1840 s and 1850s. The needs of both Union and Confederate armies gave these reforms additional impetus. "Cleanliness, order and ventilation" helped define the elements of a modern hospital. While the patient base remained the dependent - the urban working poor, merchant seamen, or anyone who lacked local familial connections -

${ }^{70}$ Vogel, "Transformation of the American Hospital", pp. 106107.

${ }^{71}$ Rosenberg, The Care of Strangers, p. 274.

72 Vogel, "Transformation of the American Hospital", p. 109. 
the institution underwent significant professionalization of administrative and nursing staff in addition to strengthening educational affiliations. 73

Paternalism and authoritarianism were the framework upon which the hospital was founded. The social distinctions between the patients and doctors were used to encourage the proper respect and deference, but there were further ramifications 74 . In the public hospitals, charity: patients were expected to exchange their privacy and cooperation as clinical exercises for student doctors. While doctors reassured students that the patients welcomed the medical attention, most evidence suggested just the opposite; patients feared and resented these clinical experiences. 75

\section{Catholic Hospitals}

The expansion of Catholic hospitals in the United States was a result of the Church's commitment to aid the suffering. Additionally, these institutions provided a sympathetic refuge for an often harassed Catholic population. The Catholic hospitals allowed patients to avoid the stigma of charity by charging a small fee. Additionally, these institutions accepted chronic cases and aged patients who were frequently refused admittance to other hospitals. 76 The Catholic

${ }^{73}$ Rosenberg, The Care of Strangers, pp. 98-99, 190-208.

${ }^{74}$ Vogel, "Transformation of the American Hospital", p. 108.

${ }^{75}$ Rosenberg, The Care of Strangers, p. 207.

${ }^{76}$ Rosenberg, The Care of Strangers, pp. 111-112. 
hospitals successfully attracted the patient of limited means by providing personal and familiar circumstances. The sisters who staffed the facilities were generally adept at comforting a patient during a traumatic hospital visit. Additionally, their unpaid labor was an essential factor that promoted the hospital's success. ${ }^{77}$

Around the nation, communities took pride in their hospitals. Religiously-affiliated groups viewed their institutions as symbols of community identity and respectability. Small towns saw them as evidence of modern society. ${ }^{78}$ Thus, the institution began to shed its moral baseness and was perceived as the mark of a rational and advancing society.

Many forces served notice to the "orthodox" medical profession that change was inevitable. The root problem for all physicians was that their methods failed to secure beneficial results and patients often got worse rather than better. One contemporary doctor noted "every practical physician is aware of the frequent failure of all kinds of medication."79 Patients resisted the traditional "heroic" practices of the orthodox physicians. In general, the American public was encouraged to take control of its own destinies, including health care. Many contemporaries applauded the effort to wrest away the special status and privileges of doctors, especially in light of their

${ }^{77}$ Rosenberg, The Care of Strangers, p. 240.

${ }^{78}$ Rosenberg, The Care of Strangers, p. 8.

79 Billy M. Jones, Health-Seekers in the Southwest, 1817-1900 (Norman, OK: University of Oklahoma Press, 1967), p. 38. 
failure to secure consistent results. Popular philosophy held that people could be educated sufficiently to act as their own physicians, and in those cases where self-medication failed, there were competitive medical sects that offered alternative therapies. Thus, patients had the freedom to choose between traditional medicine, newer sects, or self-help. As the century progressed, so did medicine as a science and the hospital as a healing institution. Yet for the most part, the nineteenth century represented an era of uncertainty and upheaval, where serious challenges were made to traditional medical practice. 


\section{CHAPTER V}

\section{HEALTH FORMULAS}

The nineteenth century was a lucrative era for health writers and publishers alike. Health publications abounded. Many claimed to know the secrets of attaining health and treating illnesses. The concern about health was widespread and authors had an eager audience. In rural areas, particularly on the frontiers, works such as Gunn's New Pamily Physician became the definitive source of home treatment and is perhaps rightly classified as the "chief medical aid in the West." 1

Many domestic health publications were intended for the lay audience and covered a vast range of topics: the water cure, faith healing, venereal disease, temperance, higher education, hair tonics, cures for disease, formulas for healthful living. Almost no aspect of contemporary life went unnoticed by these writers.

Most of the health recipe books were dedicated to "the people...based on the assumption that every man...has a right to all the knowledge he is capable of acquiring on all subjects, medicine not excepted."2 One writer suggested that, "the general lack of

1John Duffy, The Healers (New York: McGraw-Hill Book Company, 1976), pp. 126-127.

${ }^{2}$ Ira Warren and A. E. Small. The Household Physician; for the use of Pamilies. Planters. Seamen and Travelers (Boston: Ira Bradley and Company, 1878), preface. 
knowledge respecting medicine and the laws of life and health, and disease, renders people capable of being made the easy prey of the villainous quack." 3 Thus, educating the people via such works helped not only the patient, but deterred questionable practices and practitioners.

\section{PROMOTIONAL LITERATURE}

Some texts were written specifically to sell products. For example, A Domestic Guide to Medicine by Dr. Joseph Ralph advocated Hygiene Vegetable Pills. This product was a purgative, designed to "clear and purify the blood" in order to correct disorders of the stomach, liver and bowels, restoring organs of digestion to their natural, healthy state. Dr. Ralph apparently believed that when the digestion of food was incomplete, the blood was burdened with "impure and half-digested particles" which circulated through the body irritating other organs that responded by developing diseases. Thus, his pills were designed to cleanse the blood cutting off the supply of harmful material in order to prevent the occurrence or recurrence of disease. 4

other like-minded authors found greater economic opportunities in promoting entire lines of medicines. Dr. David Jayne assured readers that the popularity of his 'Pamily Medicines' was not

3John C. Gunn, Gunn's New Family Physician: Home Book of Health (Cincinnati: Moore, Wilstach and Baldwin, 1858, 1864), p. 5.

${ }^{4} J o s e p h$ Ralph, A Domestic Guide to Medicine (New York: General Office of the Genuine Improved Hygeian Pills, 1834), p. 16. 
limited to the "illiterate and credulous, but [included] innumerable persons of intelligence and character" who occupied the most prominent stations in life. 5 Jayne sold his expectorants, pills and tonics packaged with almanactype information such as moon phases, eclipses, and holiday occurrences.

Most health publications were not product promotions. Many were sincere attempts to propose practical precepts for people to live by, while others sought a medium to preach their reforms or biases against contemporary culture.

\section{Wresting Control Away from the Doctors}

. Health writers were avid supporters of the self-help approach, much to the dismay of many professional physicians. These authors propounded the tenet that any educated man could act as his own physician. ${ }^{6}$ Physicians were often portrayed as unchanging and oldfashioned authoritarians who decried "every new discovery made outside their circumscribed investigation." 7 They brought "disgrace upon their profession by sustaining the dark shadows of ancient

${ }^{5}$ David Jayne, Jayne's Medical Almanac and Guide to Health for Washington, Oregon. California, Utah and Sandwich Islands for the year 1859 (Philadelphia: James S. McCalla, Printer, 1859), p. 1.

${ }^{6}$ Gunn, Gunn's New Pamily Physician, p. 5.

${ }^{7}$ Rosa Cadman Congar, The Educator: Cause and Cure of All Diseases, 2nd Edition (Chicago: Educator Publishing Company, 1888), p. 14. 
superstitions, instead of advocating the improvements of modern times." 8

\section{Source of Disease}

Some health books explicitly stated that people caused their own diseases. People "ought to direct their...complaints against their own follies and perversity, in often disobeying the dictates of reason and conscience, and so forfeiting that happiness and health which...has [been] placed within their reach." 9 Another writer suggested a rather esoteric multi-causal explanation for disease that challenges even the most agile intellect to decipher. She initially proposes that "ignorance is the absolute cause of all disease" but goes on to state "all disease originates in the mind" and still later asserts that poor ventilation and "all excesses" are most frequently the causes of disease. ${ }^{10}$ While this delineation of etiology was apparently coherent for the author, the reader must decide whether ignorance, psychosomatic illness, miasmic airs or "fast living" is the ultimate source of their ills.

If people were ultimately responsible for their own condition, it followed that prevention through education was vital to health. As one writer noted: since "the underlying cause of disease is

\footnotetext{
${ }^{8}$ Gunn, Gunn's New Family Physician, p. 5.

${ }^{9}$ Gunn, Gunn's New Family Physician, p. 7.

${ }^{10}$ Congar, The Educator, p. 19.
} 
ignorance of the laws of health...we deal with causes more than with effects." 11

Another author took this premise even further; if adult diseases were preventable, disorders of children "99 times in every 100" could be avoided. He suggested that the three controllable factors were errors of diet, neglect of proper clothing, and exposure to cold, which accounted for the "dreadful mortality among children in this country." 12 From this standpoint, parents ultimately carried full responsibility for their children's health and well-being.

THE ROAD TO HEALTH

Most health writers viewed "common sense" as a key ingredient in the health formula. One of the most frequently recommended procedures was to breath "pure air, summer and winter, day and night."13 Given the contemporary belief in miasmic disease vapors, the focus on air and ventilation is understandable. Some authors suggested that bedrooms should be large enough to supply an appropriate amount of pure air throughout the night. 14

11 Congar, The Educator, pp. 14, 19.

12 Ralph, A Domestic Guide to Medicine, pp. 104-105.

13 Congar, The Educator, p. 31. Warren, The Household Physician, pp. 110-111. Gunn, Gunn's New Family Physician, p. 151. William A, Buchan, A Treatise on the Prevention and Cure of Diseases by Regimen and Simple Medicines (Cincinnati: J.A. James Publisher, 1841), p. 55.

14 Warren, The Household Physician, p. 97. 


\section{Exercise}

To secure health, exercise in the fresh air was a highly recommended activity. Many writers lauded horseback riding proclaiming that "nothing can exceed the value of this exercise."15 Where horses were unavailable or undesirable, walking was a frequently recommended activity. 16 Most writers believed that health could not exist without exercise and that such pursuits "must be regular and pleasurable -- connected to a pleasing occupation" such as gardening. 17 As one author noted, "cultivation of a garden was highly conducive to health" because it paid off twice: first as fresh air exercise and second as a source of healthful vegetables. 18 Writers observed that rates and types of exercise should vary in different periods of life so that "running and leaping -- used with prudence by the young and healthy" would produce a "high degree of agility and endurance," while passive exercise such as sailing or riding was "good for those unable to partake of more vigorous activities." 19

${ }^{15}$ quote in Gunn, Gunn's New Family Physician, p. 184. See also Buchan, A Treatise on Prevention, p. 45.

${ }^{16}$ Gunn, Gunn's New Family Physician, p. 184. Buchan, A Treatise on Prevention, p. 45.

17 Warren, The Household Physician, p. 89.

18 Warren, The Household Physician, p. 89.

19 Warren, The Household Physician, p. 89. 


\section{Cleanliness}

"Bathing is too much neglected in this country," suggested one author who believed that cold bathing, of all preventive measures, was the "greatest safeguard against various diseases." 20 Most writers agreed; bathing and cleanliness were critical elements to health. 21 one writer suggested that sunshine was the only remedy which surpassed cleanliness. Another postulated that the critical aspect of "keeping the pores open" was the crucial element which secured health. On this one point most all health writers agreed -Americans needed to bathe more frequently.

\section{Food and Diet}

Health writers may have varied on specific recommendations, but they agreed on the principle that diet was an integral part of the health plan. Some had very specific outlines such as eating only "hygienic foods," which meant no animal foods, especially pork.22 Others were less adamant, but recommended that the diet should be "plain and simple foods" and that while bread was the "staff of life," Americans eat "more bread than is conducive to their health." 23 still others disagreed. "For the man who uses his brain a great deal, there is no other one article of food equal to bread made from

${ }^{20}$ Gunn, Gunn's New Family Physician, pp. 169, 173.

${ }^{21}$ Congar, The Educator, p. 32, Warren, The Household Physician, p. 98.

${ }^{22}$ Congar, The Educator, p. 32.

23 Buchan, A Treatise on Prevention, pp. 72, 14. 
unbolted wheat flour... Wheat when not deprived of the bran...is perhaps the very best supporter of animal life." 24 Fruits, vegetables and rice were applauded as life sustaining foods while animal products were most commonly identified with potential problems. 25 While some writers did not suggest dietary restrictions, they were concerned about overindulgence. Readers were advised to rise "from the table with stomach unoppressed." 26 Thus, health writers of the era were firmly convinced that what goes into a body determined its ability to function efficiently and effectively against the uncertainties of life.

Closely aligned with dietary recommendations were admonitions against alcohol. Most authors warned readers that alcohol was "poisonous and life destroying," and that temperance was the "parent of health." 27 Others sidestepped the issue by suggesting moderation was the appropriate response or that consumption of non-distilled products was acceptable while stronger spirits were not.28 As a general observation, no one advocated alcoholic beverages to promote health.

24 Warren, The Household Physician, pp. 71, 77.

25 Congar, The Educator, p. 32. Warren, The Household Physician, p. 71.

${ }^{26}$ Gunn, Gunn's New Family Physician, p. 147.

27 Congar, The Educator, p. 20. Buchan, A Treatise on Prevention, p. 71. Gunn, Gunn's New Family Physician, p.34. John M. Peck. Mid-American Frontier: A Guide for Emigrants, (New York: Arno Press, 1975, 1831), p. 223.

28 Buchan, A Treatise on Prevention, p. 63. Warren, The Household Physician, p. 71. 


\section{Rest, Recreation and Travel}

Rest, recreation, and travel were important elements of life according to health writers of the era. Many identified insufficient sleep as a "health destroyer," but at the same time warned that "no piece of indolence hurts the health more than the modern custom of lying a-bed too long in the morning."29 Most agreed that sleep for adults should range between seven or eight hours per night. ${ }^{30}$ The motto "early rising" described the general sentiment of the appropriate time to emerge from the bed chamber. As with most general health categories, children received specific advice and attention with regards to sleep. One writer suggested that children would benefit by sleeping for as long as they liked. 31 It is difficult to determine if many parents followed this advice.

"Labor, whether of hand or brain, or both together, demands not only rest, but also relaxation. This has become a generally conceded principle of mental and physiological science, which the most rigid and austere will hardly gainsay." 32 Many authors agreed

${ }^{29}$ Congar, The Educator, p. 19. Buchan, A Treatise on Prevention, p. 61 .

30 Buchan, A Treatise on Prevention, p. 63. Warren, The Household Physician, p. 97. Gunn, Gunn's New Family Physician, p. 147.

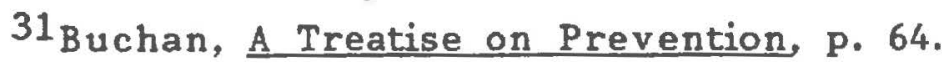

32 "Recreation" Oregon Statesman 20 sept 1859, 2:1. 
on the necessity of suitable relaxation from "the daily cares, anxieties and fatigues of all employment." 33

Travel topped the list of recommended recreational activities that promoted health. Health writers believed that a change of location was helpful in many different ways. In fact, traveling for health was often prescribed by physicians in chronic or troublesome cases. Extended sea voyages were favored for extremely ill patients. However, such travel was generally cost-prohibitive for most Americans. Many health care professionals believed that the method of travel itself might directly promote health. Overland journeys implied a certain level of physical activity on the part of the sojourner. This bodily exertion coupled with the fresh air and simple diet were held in high regard by many physicians. Over time such travel, especially to the Southwest, became a favorite recommendation of Eastern and Midwestern doctors. 34

Beyond the medicinal use of travel as a restorative, health writers applauded travel because of the "variety of pleasing impression it makes upon the mind."35 one writer praised the railroads which afforded the enjoyment of fresh country air for

33"Recreation" Oregon Statesman 20 Sept 1859, 2:1. The implied audience of this article (and in general of the health texts) is masculine. It is difficult to find anyone that advocated a similar break for females from their daily chores.

${ }^{34}$ Billy M. Jones, Health-Seekers in the Southwest, 1817-1900 (Norman, OK: University of Oklahoma Press, 1967), pp. 38-39.

35 Warren, The Household Physician, p. 55. 
urban citizens. ${ }^{36}$ Travel for both the sick and the healthy was held to be a worthwhile endeavor.

\section{Mental Health}

"Music is a magical remedy in many cases of melancholy" noted one author while another believed that music soothed the mind.37 Most agreed that some attention must be paid to mental activity. "Health requires that the Brain should be properly occupied with vigorous thought -- use improves its strength and vigor...[however] use discretion in exercising the Brain -- permit it to rest."38 Another writer suggested the "proper regulation of all passions" was "essential and important to health" because emotions held a "powerful influence over the general health." 39 Thus, exercise and recreation of both the body and the mind were recognized by health writers as crucial elements in a holistic approach to health.

\section{CULTURAL COMMENTARY}

\section{"Right Living"}

Many authors implied that disease equated with immoral behavior while good health provided evidence of virtuous living. Contemporaries noted that "while the careless and the licentious

${ }^{36} \mathrm{Gunn}$, Gunn's New Family Physician, p. 151.

37 Congar, The Educator, p. 32. Buchan, A Treatise on prevention, p. 44.

38 Warren, The Household Physician, pp. 58-59.

${ }^{39}$ Gunn, Gunn's New Family Physician, p. 15. 
suffer, the temperate, circumspect and orderly portion of the community usually escape" the effects of disease. 40 Answering these observations, one writer proclaimed "we teach how to prevent disease by right living." 41 Some health advocates believed that the "cultivation of Christian virtues" was the only rational mode of securing health and life. 42 Another wrote, "pure and well-regulated moral affections" were essential for human well-being; thus "turbulent and evil passion must necessarily corrupt the health."43 People were responsible for their own diseases and their illnesses illuminated their moral being, offering friends and neighbors the opportunity to judge for themselves the righteousness of the afflicted.

\section{The Female Gender}

The physical and biological differences between women and men necessitated that health writers treat female health issues as extraordinary phenomena. The cultural model of nineteenth century American life reinforced this notion of separate sexually-defined spheres. Most books had chapters that dealt specifically with women

40 James H. Cassedy, American Medicine and Statistical Thinking, 1800 - 1860 (Cambridge: Harvard University Press, 1984), p. 30.

${ }^{41}$ Congar, The Educator, p. 14.

42Warren, The Household Physician, preface.

${ }^{43}$ Gunn, Gunn's New Pamily Physician, p. 97. 
or children. It is interesting to note that few had similarly dedicated chapters for men.

For the most part, health writers did not challenge the contemporary view of domestic female roles. Kitchen skills and bedside manner were held as appropriate female contributions to family health. One writer proclaimed,

In no situation, and under no circumstance, does the female character appear to such advantage as when watching beside the bed of sickness. The chamber of disease may indeed, be said to be woman's home. We there behold her in her loveliest, most attractive point of view; firm without being harsh; yet not weak; active, yet quiet; gentle, patient uncomplaining, vigilant.44

Women were reminded of their spiritual duties and their "obligations to the world...[to] purge the earth of disease and sin" by providing the proper foods upon their tables and the right example in their homes. 45 Women were expected to be more interested in health concerns than men. Most home gardens, which were generally under the guidance of women, included an assortment of medicinal herbs. 46

Even when they lived together, American women and men occupied separate spheres. In health care issues, men and women were distinctly judged and condemned. It was perceived that men abused their bodies with alcohol, tobacco, or "inordinate mental

${ }^{44}$ Gunn, Gunn's New Family Physician, p. 117.

${ }^{45}$ Congar, The Educator, p. 41.

${ }^{46}$ Harriet Nesmith McArthur, "Recollections of the Rickreall." Oregon Historical Quarterly (December 1929): pp. 375-376. 
labor," i. e., too much ambition. 47 Women on the other hand suffered "a score of [health] terrors arising from fashion, vanity or ignorance." 48 Thus, while men were over-ambitious and neglectful to the detriment of their health, women were vain and ignorant toward that same end. Most health writers attacked women's fashions, especially the use of constricting devices such as corsets. 49

\section{Backlash}

Many health writers were caught up in the spirit of reform. Others used their book as a forum to air their particular views of modern society. For example, one writer lamented the perceived physical inferiority of contemporary man. "Moderns are inferior in bodily strength to ancient Greeks and Romans...[who] strove to make the most of the present and took measures to ensure health and long life." 50 The author cited western religion as the source of this difference between ancient and contemporary society. He reasoned that "prior to Christianity, men had very little concern about the future." 51

Other underlying backlashes against contemporary societal values crept through in the works of the health writers. In the

\section{${ }^{47}$ Gunn, Gunn's New Family Physician, p. 267.}

${ }^{48}$ Gunn, Gunn's New Pamily Physician, p. 267.

${ }^{49}$ Buchan, A Treatise on Prevention, $p$ 67. Gunn, Gunn's New Family Physician, p. 267.

50 Warren, The Household Physician, p. 89.

51 Warren, The Household Physician, p. 89. 
genre of the Thomsonian anti-elitism toward the medical profession, one writer put forth an anti-intellectual campaign against formal education.

In schools generally, and in universities also, the study of dead languages, and the study of scientific technicalities, has used up so much time and strength, and been so utterly inappropriate to the real demands of the age, and so repugnant to the constitutional tendencies of most young people...many a good classical scholar...h has come out of college a confirmed invalid. 52

Many health writers drew conspicuous socio-economic lines and maintained a hostile stance toward "the privileged class." Such writers explicitly identified their audience as "the mechanic, the farmer and the day laborer, as well as the professional man," since "the wealthy...those who live on the honest labor of others,...can afford to support physicians and nurses by the year and die by the laws and rules of physicians and society." 53

Hostility toward upper middle-class urban values and the "cult of domesticity" were also evident in health literature. Writers cited the wives and daughters "in what are called the better classes" as leading particularly useless lives, devoid of physical exercise or mental challenge. 54 As one writer noted,

52 Congar, The Educator, pp. 25-26.

${ }^{53}$ Warren, The Household Physician, preface. Congar, The Educator, p. 44.

54 Gunn, Gunn's New Family Physician, p. 148. 
With plenty of servants to render all manual labor;... with no particular object in life to awaken interest, they pass day after day without any physical exercise more invigorating than a stupid walk up and down the street, and with no mental employment more inspiring than the reading of a few indifferent novels, the making idle morning calls, or the spending an evening at the ball, where late hours, thin dresses, and excessive dancing and improper food, do more injury than they imagine. 55

The agrarian lifestyle was applauded as a better alternative, especially for women. Farmers' wives were afforded a "certain amount of invigorating exercise" which made them healthier than the "wives of citizens." 56 Since other writers recognized the permanence of city life, they recommended gymnastic exercises and calisthenics for young women "to give them something of the robustness of our mothers two generations back." 57

Backlashes were not just reserved for health concerns. One writer found fault with the "feminine sphere" in contemporary society. He suggested that female friendships so ingrained in the cultural life, were not necessarily appropriate alliances. These feminine relationships directly resulted from the separation of the male and female worlds and strongly supported the notion that women had more in common with themselves than with men. 58 our discontented writer wrote,

${ }^{55}$ Gunn, Gunn's New Family Physician, p. 148.

${ }^{56}$ Gunn, Gunn's New Family Physician, p. 148.

57 Warren, The Household Physician, p. 89.

58 Julie Roy Jeffrey, Frontier Women (New York: Hill and Wang, 1979), p. 10. 


\begin{abstract}
A woman forgets what is due to herself when she condescends to that refuge of weakness, a female confidante. A wife's bosom should be the tomb of her husband's failings, and his character far more valuable, in her estimation, than his life. If this be not the case, she pollutes her marriage vow. 59
\end{abstract}

His concern seemed more egotistical than anything else. He certainly failed to illuminate the actual threat (or existence) of a female conspiracy.

Not only was physical health a concern of writers, but cultural, moral and spiritual health were addressed as well. In some instances the writers approached their topic holistically, attacking all the "evils" of everyday life. Many authors saw various negative forces in American life. Some suggested that in the good old days things were much healthier and happier without offering much substantiation for their claims. Other writers were touched by cultural discontent, convinced that reform movements such as temperance were the way to gain or regain the nation's moral and physical health. Still others were trying to profit materially through book and product sales. Like most aspects of human history, multicausality produced a multi-faceted health phenomena. 


\section{CHAPTER VI}

DEMOGRAPHIC ASPECTS OF THE PACIFIC NORTHWEST

The demographic trends of population in history are but a convenient tool used to summarize part of the past experience of a given society during a given era. During the nineteenth century, migration deeply affected U.S. populations in both rural and urban settings. The U.S. population increased as large number of foreigners came to "the land of opportunity." Additionally, Americans made internal moves around the United States and its territorial holdings. Past migratory patterns are, at best, difficult obstacles to evaluate when assessing natural and migrant population increases. This discussion will not differentiate between these types of population increases since migration brought the white population to the Pacific Northwest.

\section{U.S. POPULATION TRENDS IN THE NINETEENTH CENTURY}

The U.S. population in 1860 as reflected in figures 8 and 9 , demonstrated a squat pyramid that is typical of a nation in the early stages of demographic development, i. e., a high birth rate, a high death rate and, in general, a youthful age structure. ${ }^{1}$

I W.M. Williams. Demographic Analysis. (New York: Frederick A. Praeger, Publishers, 1968), p. 15. 
In 1,000 of population

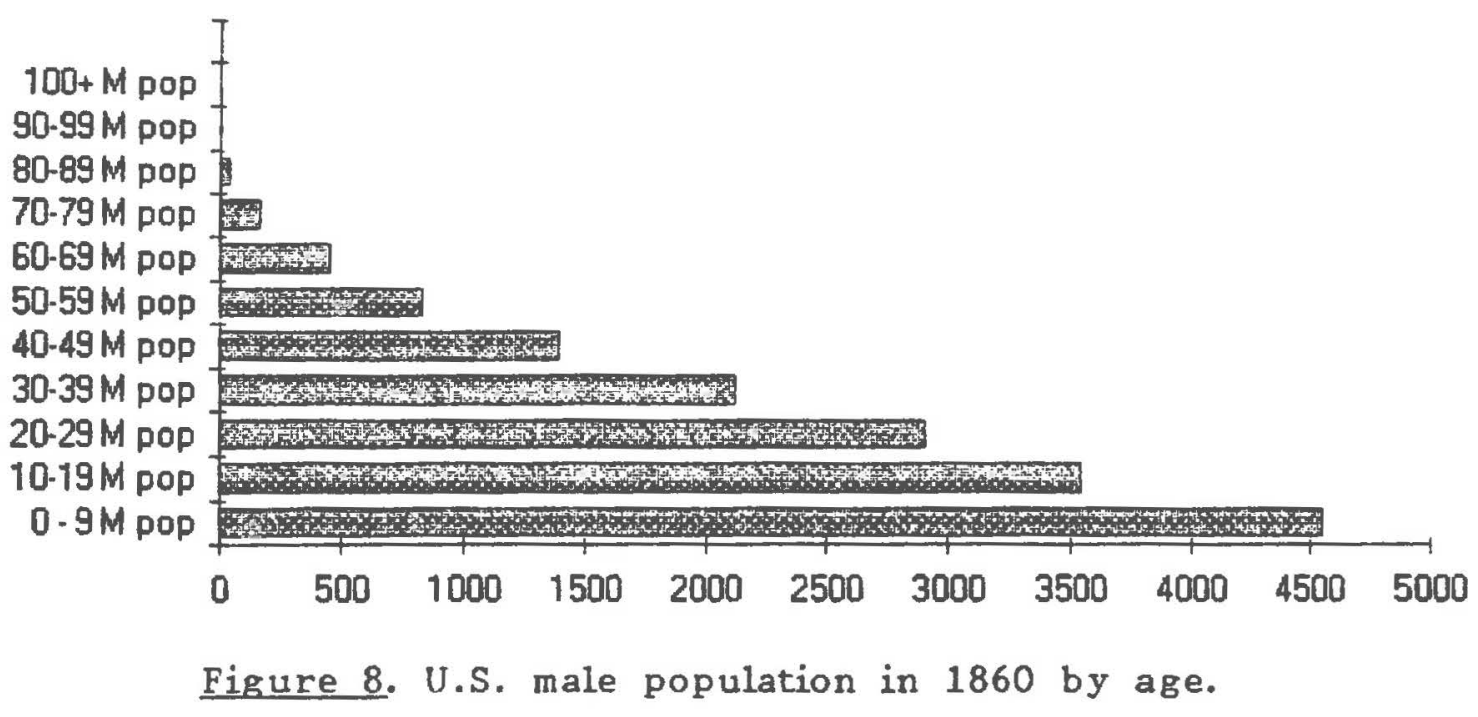

in 1000 of population

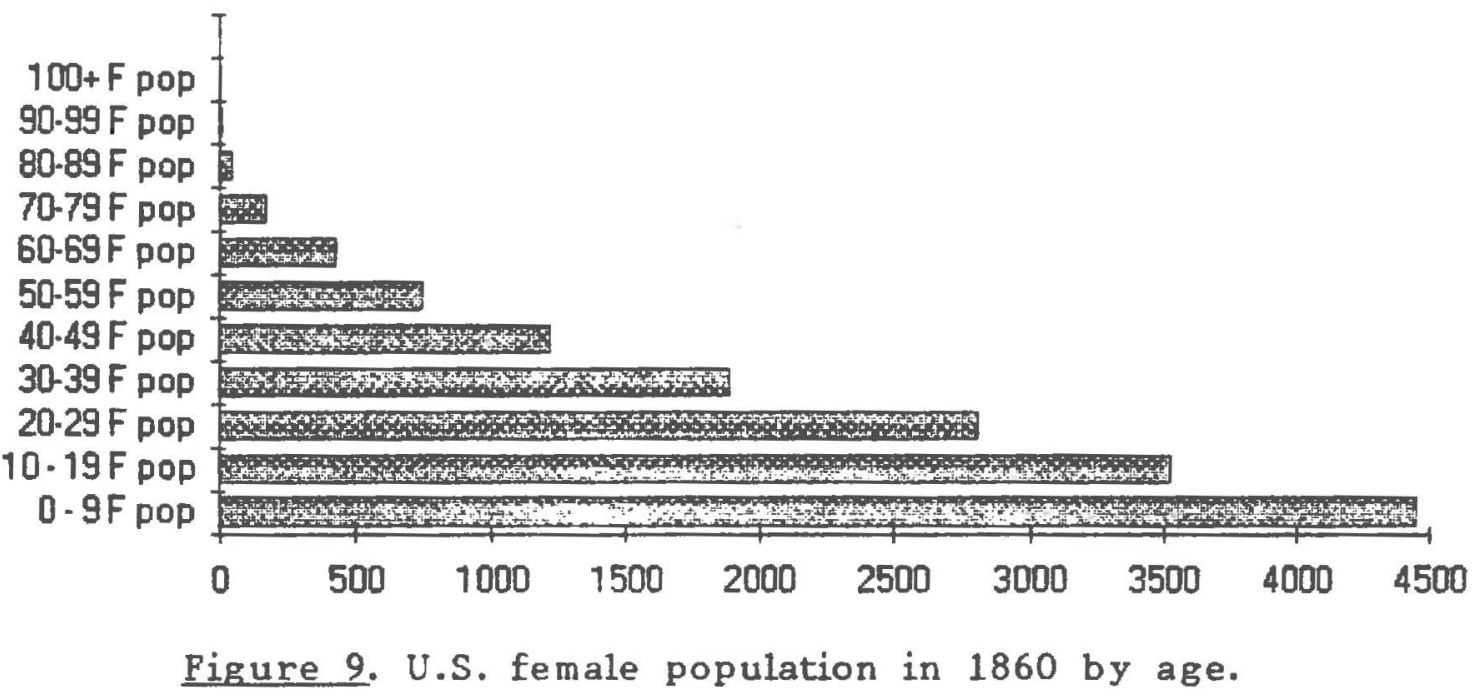

In 1860 , men outnumbered women with a ratio of 104.7 of males to every 100 females. $^{2}$ The Ninth Census of 1870 displayed similar squat

2Jos. C.G. Kennedy. Preliminary Report on 8th Census 1860. (Washington, D.C.: Government Printing Office, 1862), Table XXIII, Ages of the Aggregate Population. All 1860 population pyramids that appear in this discussion are compiled from this source. Due to graphics limitations, population pyramids appear in separate 
characteristics like the 1860 representation. In addition, the 1870 Census showed a population increase of $22.7 \%$ in the U.S. with a male to female ratio of 102.25 .3

\section{OREGON'S POPULATION CHARACTERISTICS}

Compared with Other Populations

Oregon's 1860 population pyramids as demonstrated in figures 10 and 11 had some features similar to that of the U.S. population. Oregon's female population reflected similarities to the U.S. representation. However, Oregon's male population demonstrated unusual development patterns in the age groups from 20 to 49 .

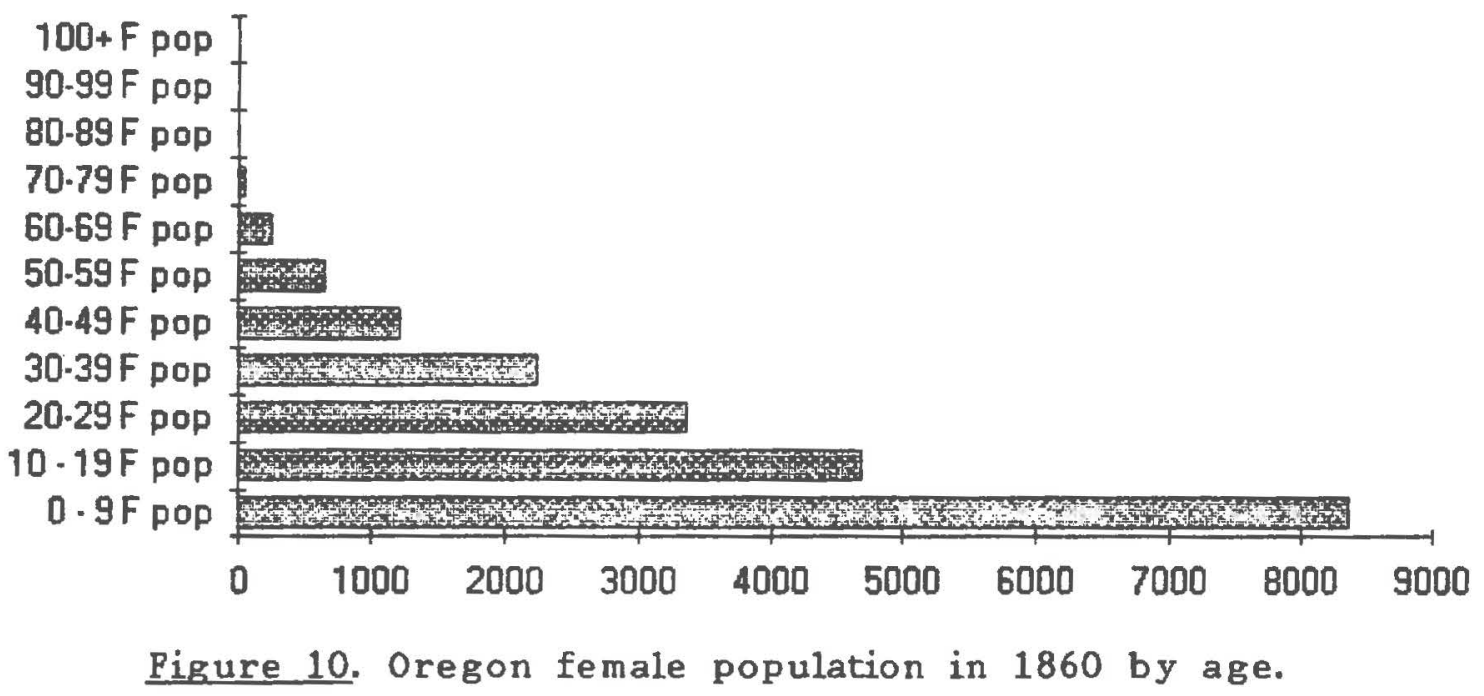

representations for males and females. In 1860 there were $16,085,204$ males and $15,358,117$ females residing in the U.S. and its territories. Male to female ratios equate the number of men to every 100 women. This is implied if not explicitly stated in all such ratios cited in the following discussion.

${ }^{3}$ U.S. Bureau of the Census. Ninth Census. (Washington, D.C.: Government Printing Office, 1872), Volume II, Table XXI: The Table of Sex, p. 536. There were $19,493,565$ males and $19,064,806$ females residing in the U.S. and its territories. 


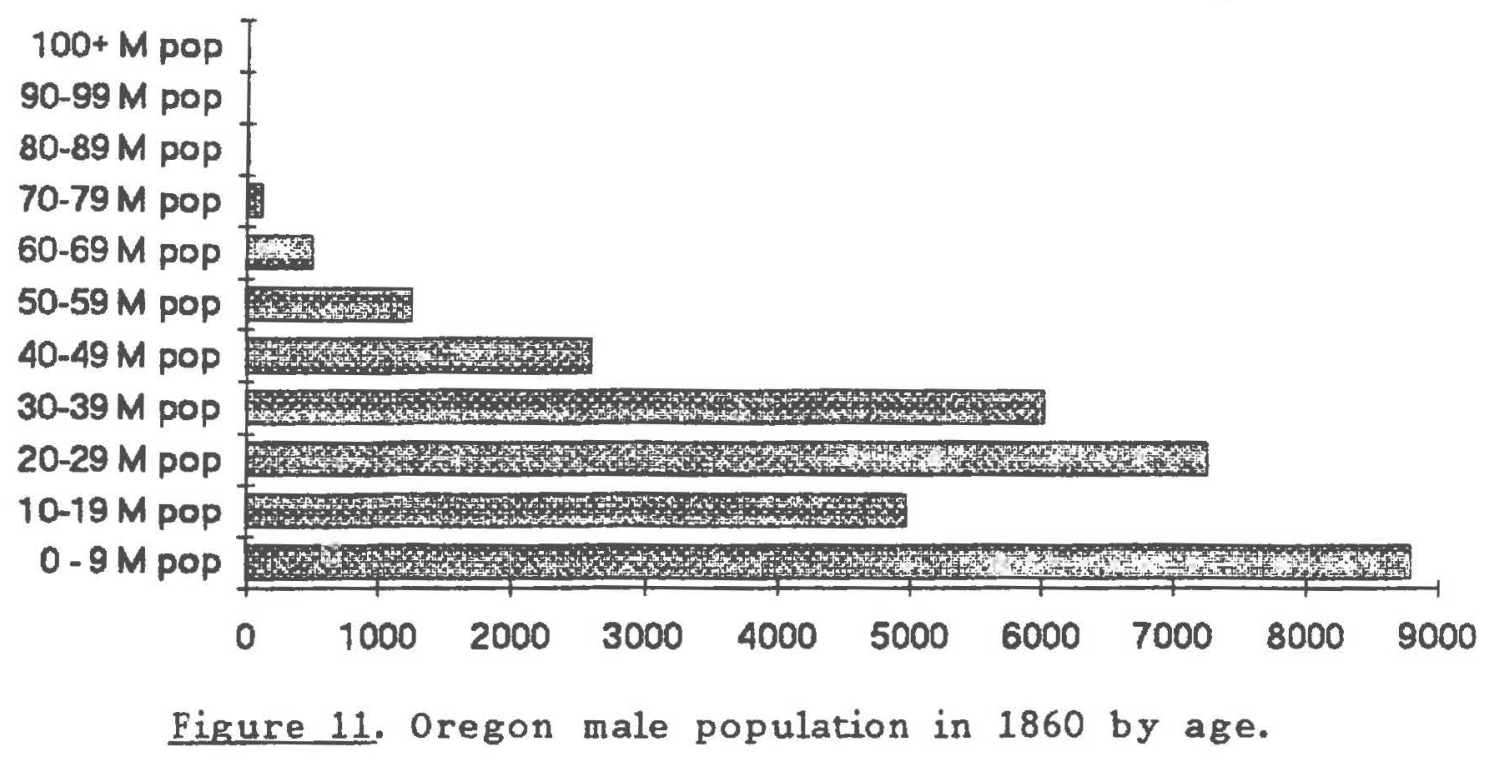

This anomaly was again manifested in the Ninth Census of 1870 for males ages 30 to 59. Thus, Oregon's population reflected a higher percentage of adult males to adult female. In 1860 , the male to female ratio in Oregon was 151.34 men for every 100 women. Sixty percent of the population was male while forty percent was female. Between 1860 and 1870 Oregon's population increased $73.3 \%$ from 52,465 to $90,923.4$ In 1870 , Oregon's male to female ratio fell slightly to 140.6 . Men now constituted $58 \%$ and women $42 \%$ of Oregon's population. In Washington Territory, the male to female ratio was significantly higher in 1860 at 268.30 than in 1870 where it was 167.21 .

For many reasons, males tended to dominate the population of frontier regions. As permanent communities developed, the male to female ratios in population moved toward a more equal ratio. This $536-545$.

${ }^{4}$ Ninth Census. Volume II, Table XXI, The Table of Sex. pp. 
settlement pattern was also illustrated in other newly settled areas such as Kansas, which reported in 1860 a male to female ratio above the national average at $123.22 .^{5}$

By the 1860 s and 1870 s, Oregon's population trends somewhat reflected trends of newly settled areas in the U.S. in general, but did not reflect "frontier" population characteristics. For example, the population pyramids of Colorado demonstrated a large population of adult males that was characteristic of frontier areas. Colorado's ratio of males to females in 1860 was 2061.22 . This ratio changed significantly by 1870. At the time of the Ninth Census, Colorado's male to female ratio was 165.0 men for every 100 women. In terms of the frontier population, it appears that wherever the men went, the women followed not long after.

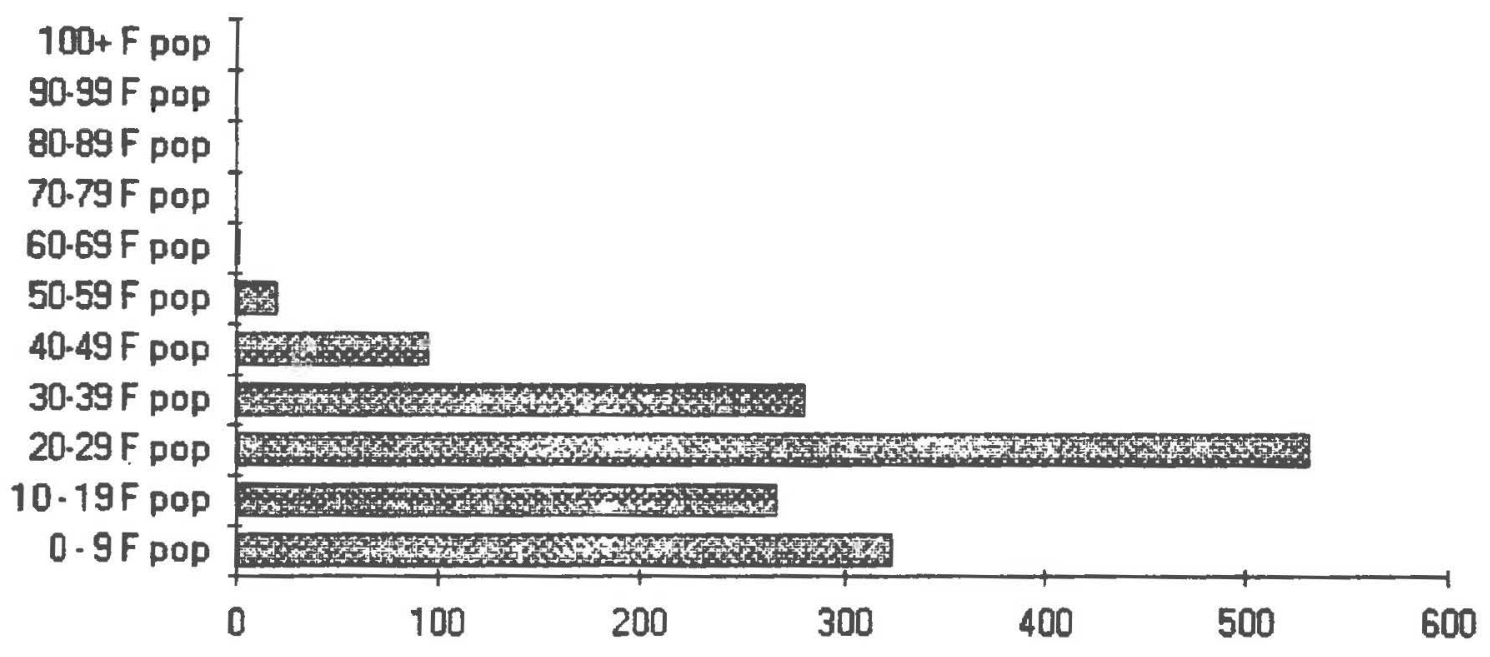

Figure 12. Colorado female population in 1860 by age.

${ }^{5}$ Eighth Census. Table XXIII, Ages of the Aggregate Population, pp. 575-577. 


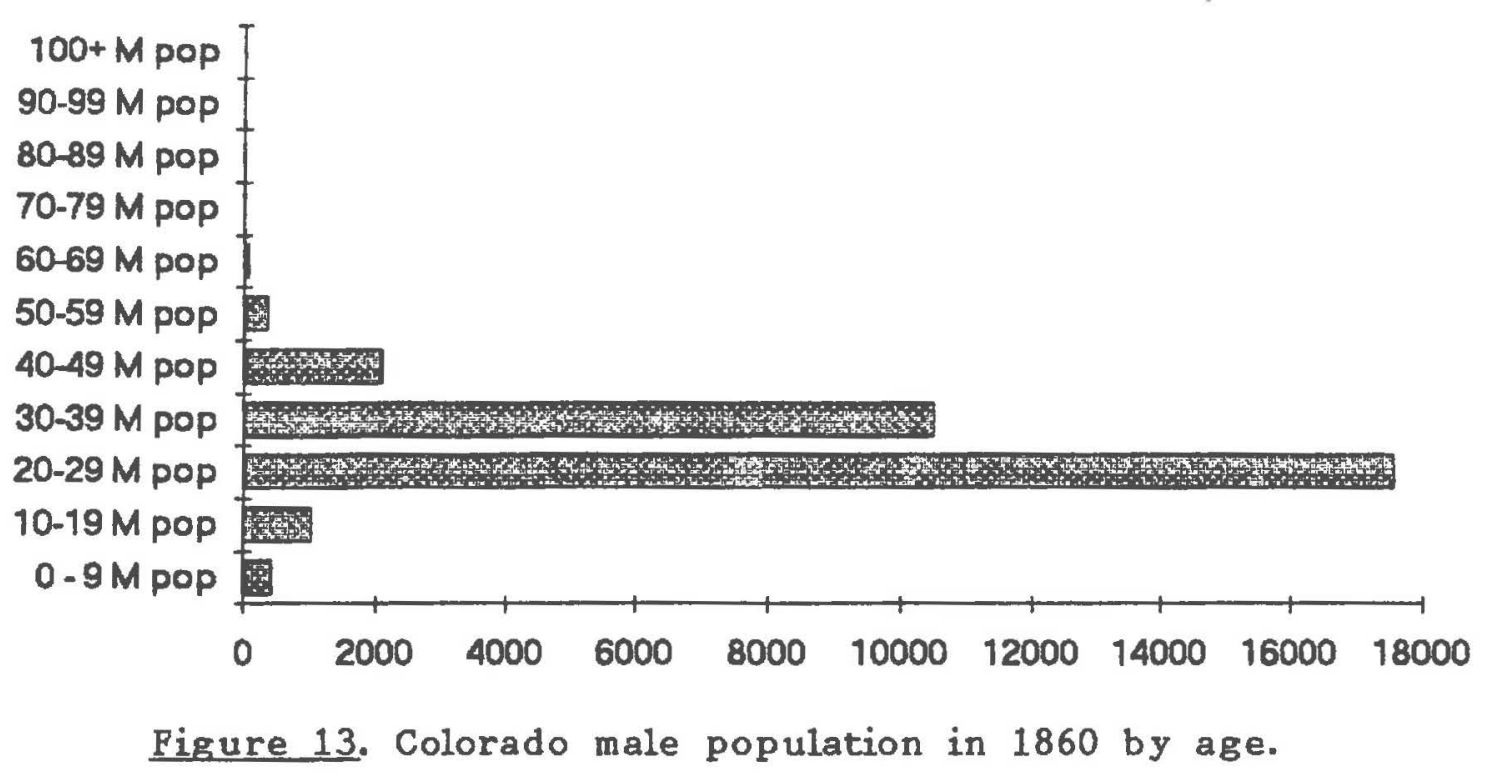

American settlement in the Oregon Territory began in earnest during the 1840 s and continued through the 1850s. When compared to other frontier regions in 1860, Oregon's population more closely resembled national trends. The Oregon Donation. Land Act of 1850 encouraged family settlement. Oregon wives held land in their own right with the number of acres dependent upon the time of arrival. If settled before December 1, 1850, wives were entitled to 320 acres to match that of their spouses. If settled after that date, 160 acres could rightly be claimed by married women. 6 Many other territories or new states such as Kansas and Nebraska, newly settled during the 1840 s and 1850 s, reflected settlement balloons in the male population more pronounced than that of Oregon.

${ }^{6}$ Gordon B. Dodds, The American Northwest. (Arlington Heights: The Forum Press, Inc., 1986.), p. 94. 

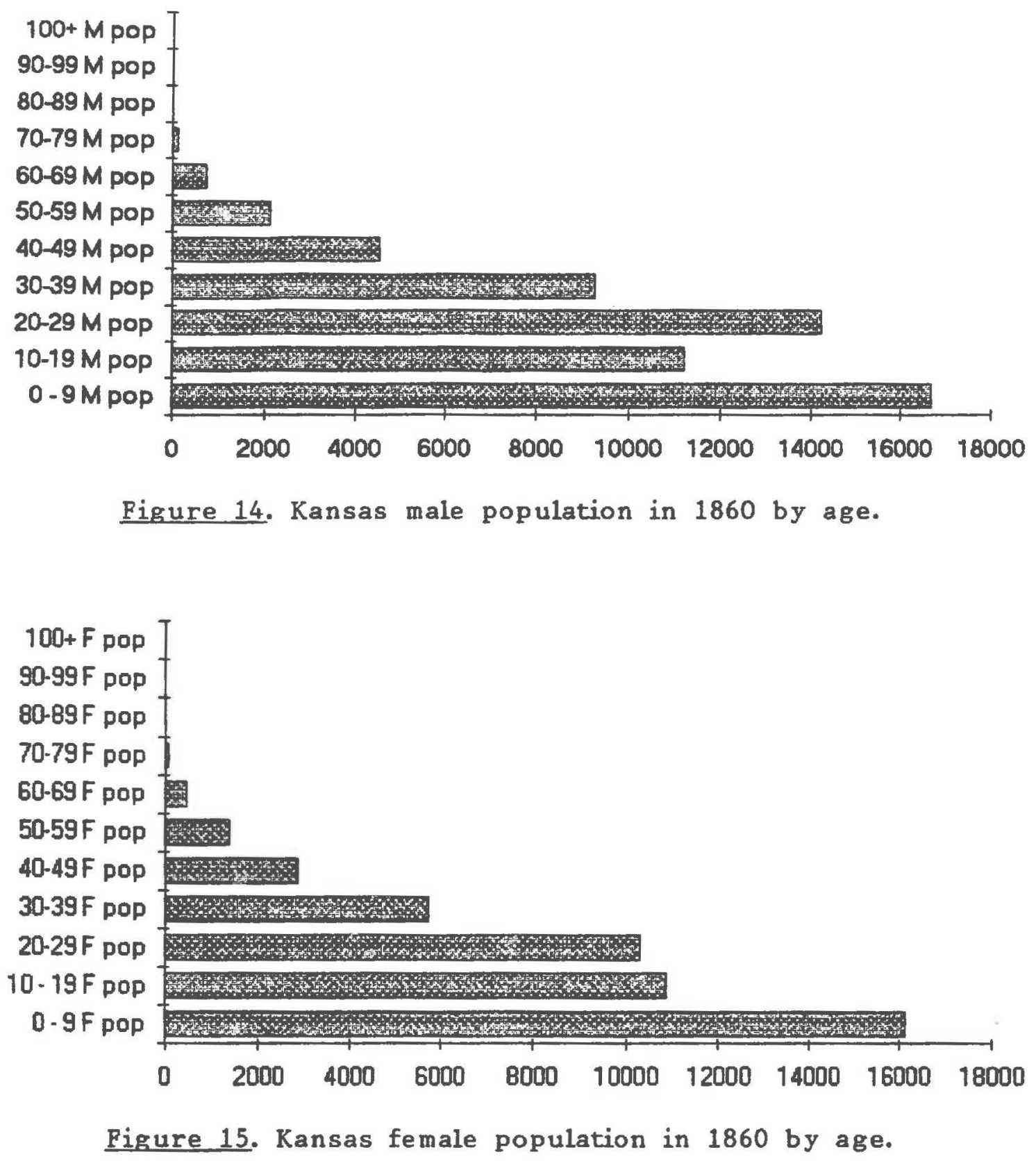

Except for gross numbers, Kansas's population pyramids in 1860 are very similar to those of Oregon. For example, the age group 0 to 9 for both sexes dominated the population structure. In Oregon almost one-third (32.8\%) of the population was under ten years of 
age. In Kansas $30.7 \%$ of the population was less than ten. Nationally, $28.7 \%$ of the population was under ten.

Nebraska, on the other hand, continued to demonstrate unusual development patterns in both the adult female and male population. On the whole, Nebraska had a smaller population than either Oregon or Kansas, and the over-representation of adults was characteristic of frontier demographic patterns. For example, women in age cohort 20-29 outnumbered women 10-19, a trend indicative of a new population influx. Likewise, men between the ages of 20-49 were a significant population group. Unlike Kansas or Oregon, Nebraskan males in the age group of 20-29 outnumbered males under the age of ten.

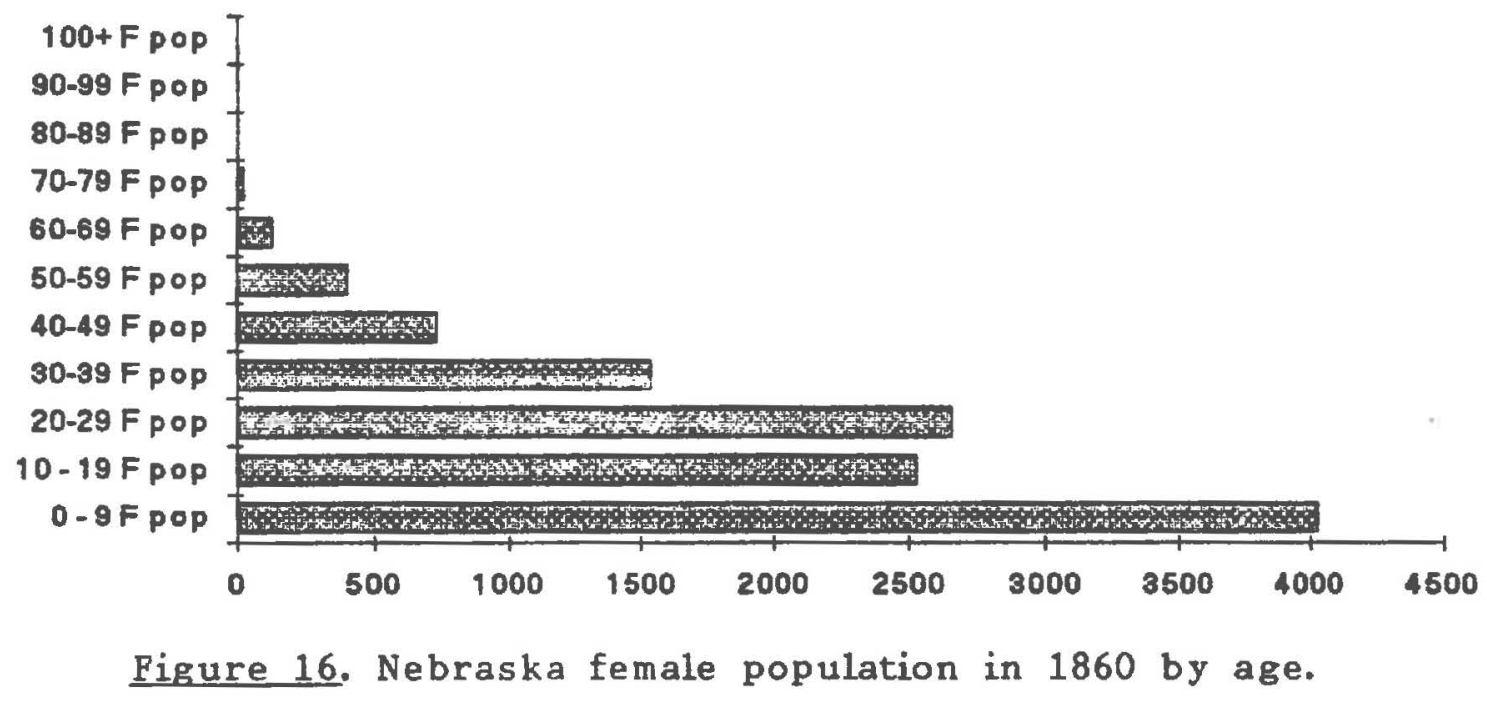




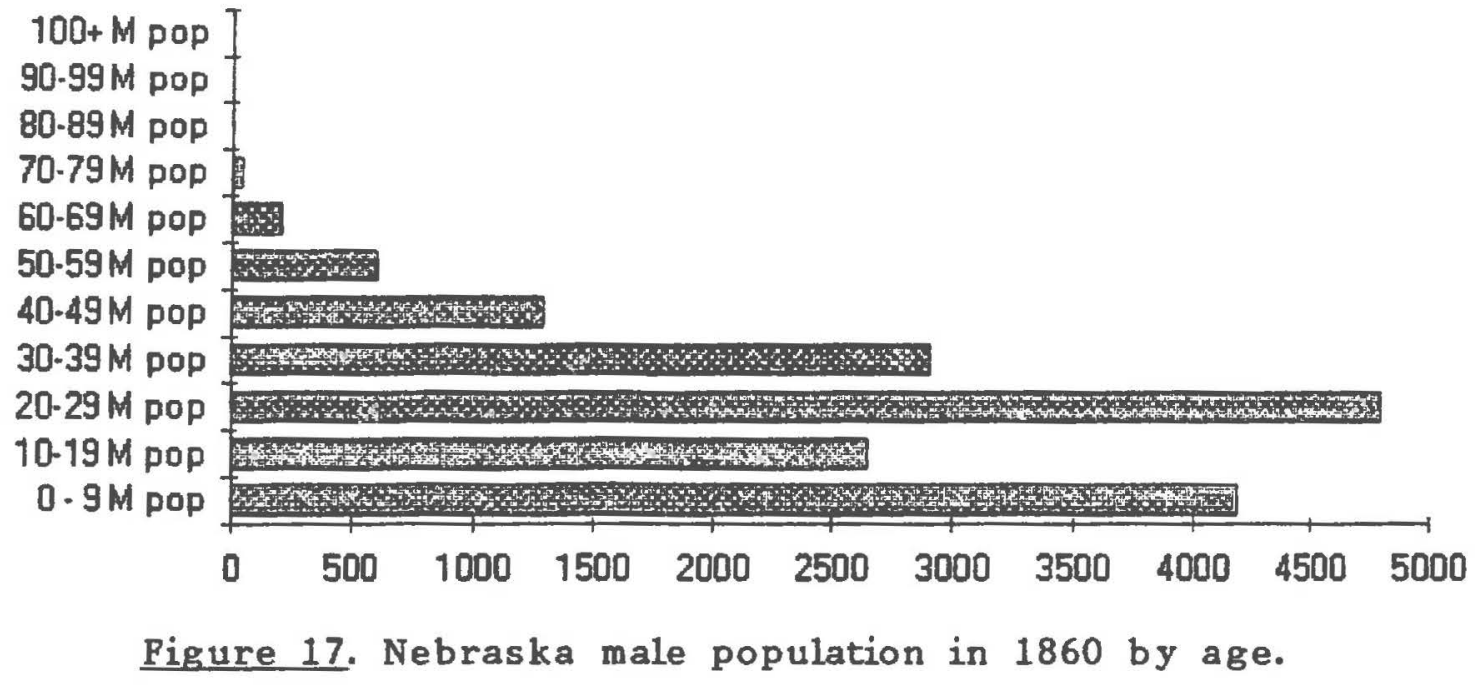

Youthful Age Structure

In 1860 , Utah reported the largest percentage of its population under the age of ten at $38.7 \%$, followed by Minnesota at $33.2 \%$, Arkansas and Iowa at 33\%. Oregon rounded off the top five with $32.8 \%$ of its population less than ten years of age. In 1870, Utah again recorded the highest percentage of population under the age of 10 at $34.9 \%$ followed by Minnesota at $30.5 \%$, Texas at $30.23 \%$, West Virginia at $30.22 \%$, and Florida at $30.2 \%$. Oregon ranked fifteenth with $28.86 \%$ of its population less than ten years of age. Nationally, $26.79 \%$ of the population fell into that grouping. ${ }^{7}$

During the 1850 s and 1860 s, Oregon had a youthful age structure as did other settling regions in the United States. In 1860 , $3.8 \%$ of Oregon's population was under one year of age, a figure above the national average of $2.97 \%$. In that same census, $18.81 \%$ of

${ }^{7}$ Eighth Census. Table XXIII, Ages of the Aggregate Population, pp. 575-577. Ninth Census. Table XXIII, Ages of the Aggregate Population, pp. 560-574. 
Oregon's population was less than five years of age, while nationally $15.40 \%$ of the population fell in that group. Utah reported the highest percentage of population under age one in both 1860 and 1870 at $5.01 \%$ and $4.1 \%$ respectively. Since the mining frontiers such as Idaho and Colorado contained a small female population, it follows that they would also reflect the lowest percentage of population under one year of age. In 1870, 2.9\% of Oregon's population was under one year of age, which was on1y slightly above the national average of $2.85 \% .^{8}$

In terms of Oregon's population trends for both males and females, the Ninth Census reflected a tendency to move toward the national averages. In $1870,15.19 \%$ of Oregon's population was less than five years of age, nationally $14.30 \%$ of the population fell in that group. 9

The proportion of the total population under the age of fifteen generally provides a fair idea of the general fertility which seemed relatively impressive in Oregon in 1860 and 1870.10 Oregon was not the most youthful state, nor was it like the mining frontiers, but rather it was an area of family development which retained an overrepresentation of adult males from the initial settlement period.

${ }^{8}$ Eighth Census. Table XXIII, Ages of the Aggregate Population, pp. 575-577. Ninth Census. Table XXIII, Ages of the Aggregate Population, pp. 560-574.

${ }^{9}$ Ninth Census. Table XXIII, Ages of the Aggregate Population, pp. 560-574.

10T.H. Hollingsworth. Historical Demography. (London: Sources of History Limited, 1969), p. 98. 


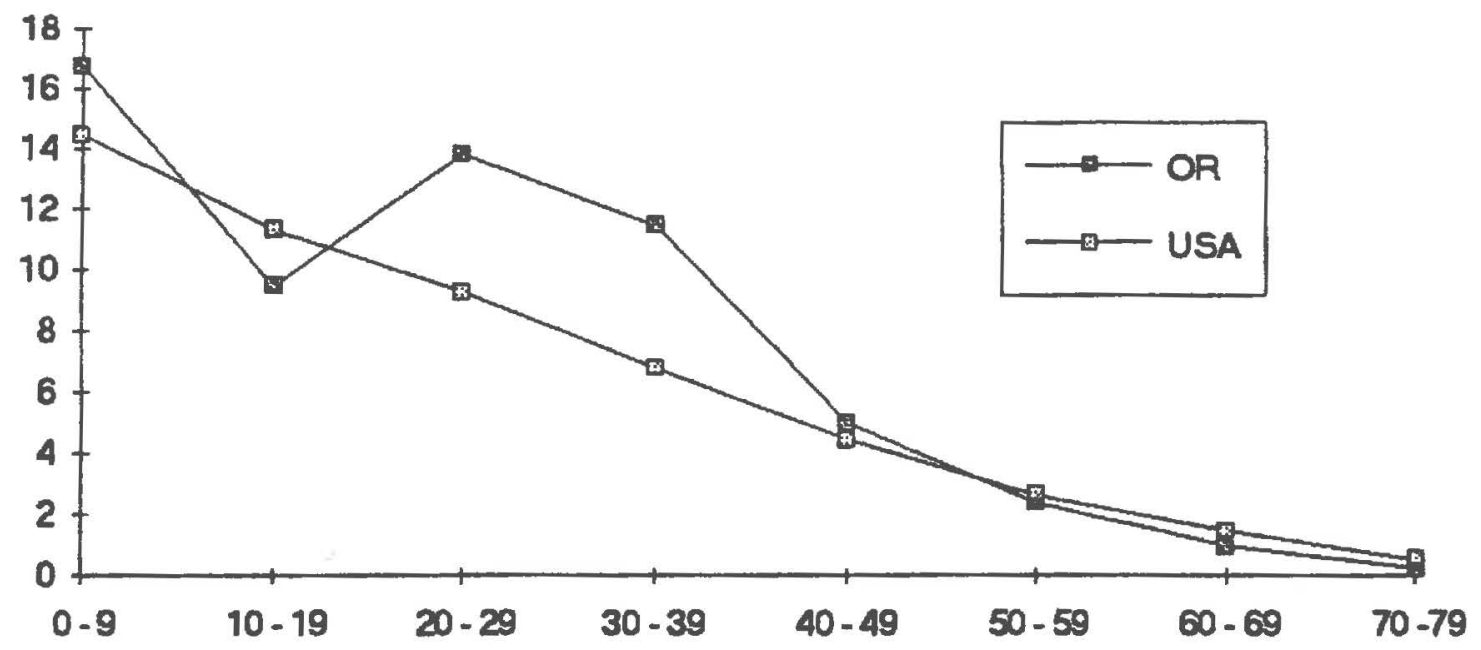

Figure 18. Male population percentages in 1860 by age.

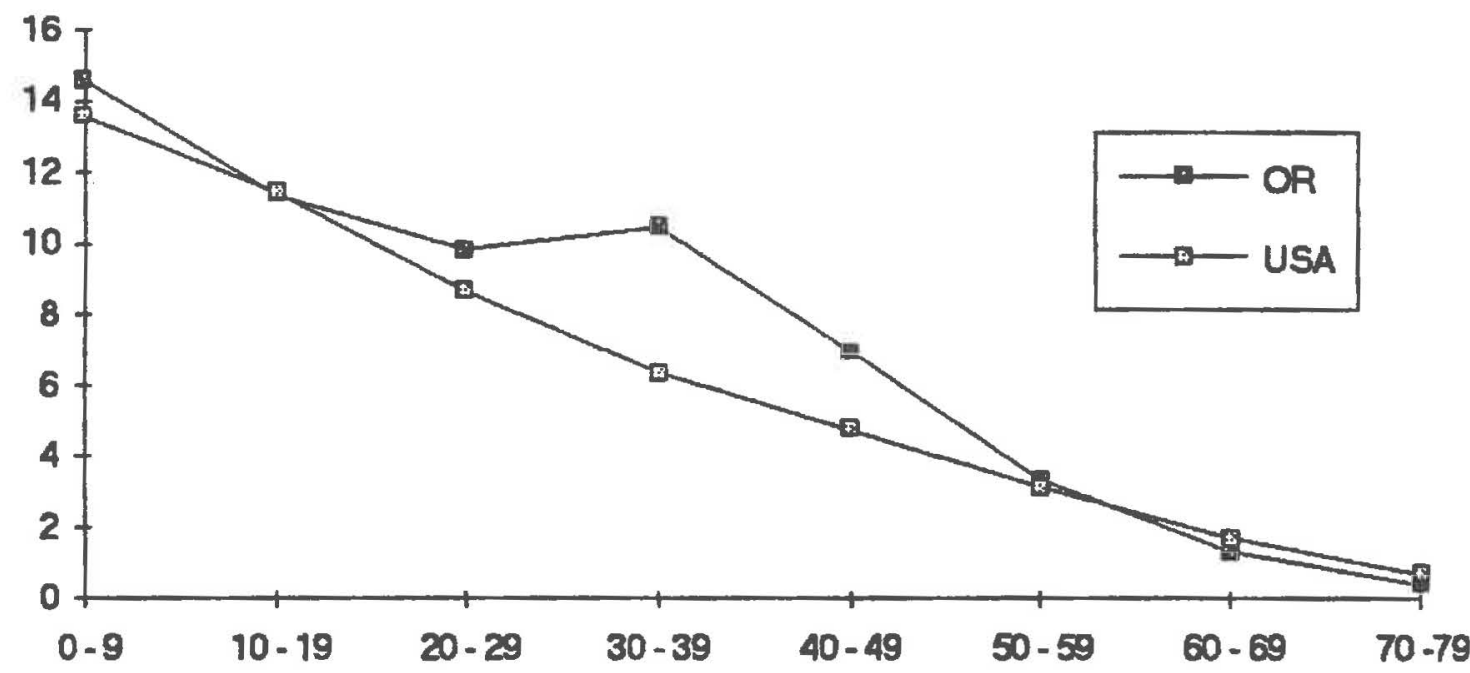

Figure 19. Male population percentages in 1870 by age. 


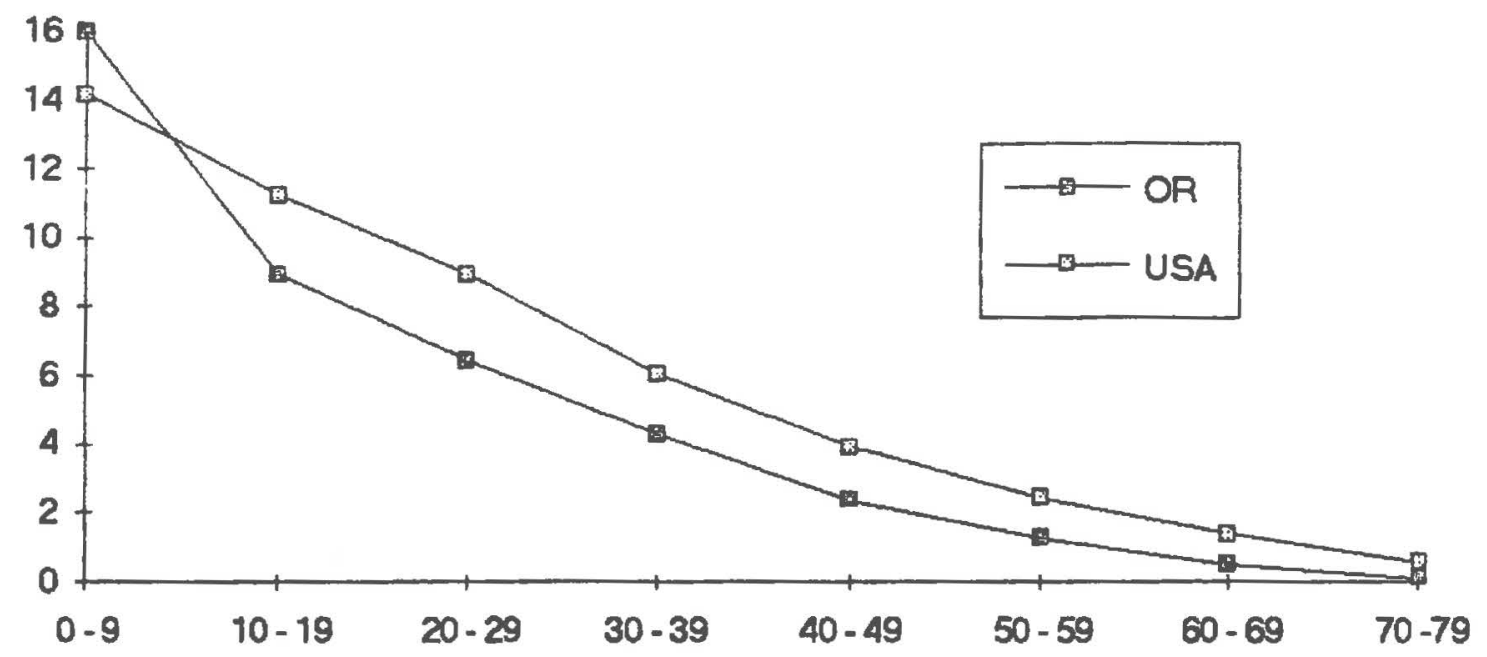

Figure 20. Female population percentages in 1860 by age.

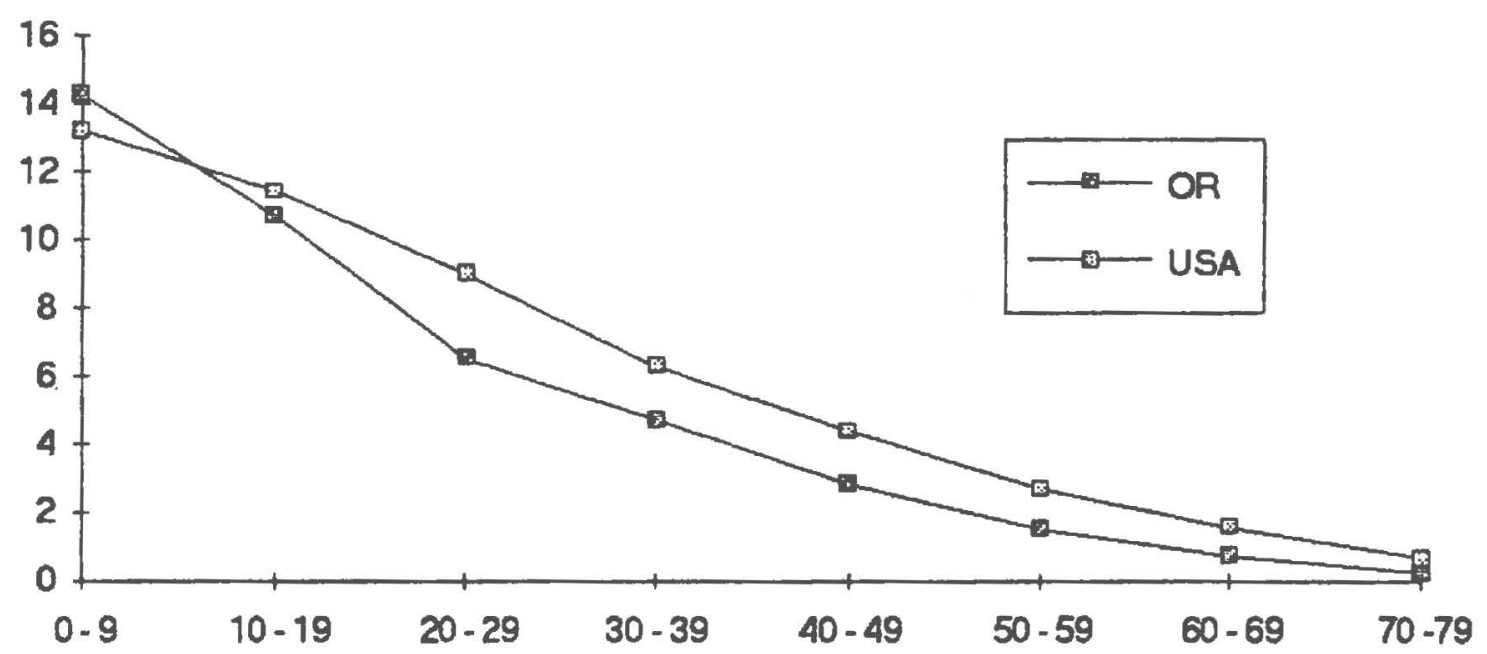

Figure 21. Female population percentages in 1870 by age.

DEATH RATES

The United States in the Twentieth Century

Before assessing nineteenth century crude death rates for the United States, Table I shows twentieth century crude death rates (for all races) by sex. 
TABLE I

TWENTIETH CENTURY DEATH RATES

$\begin{array}{llll}\text { YEAR } & \text { COMBINED } & \text { MALE } & \text { FEMALE } \\ 1955 & 9.3 & 10.8 & 7.9 \\ 1965 & 9.4 & 10.9 & 8.0 \\ 1975 & 8.8 & 10.0 & 7.6 \\ 1985 & 8.7 & 9.5 & 8.1\end{array}$

Source: U.S. Department of Health and Human Services. Vital Statistics of the United States, 1988. Vol. II. Table 1-2 Death Rates by Race and Sex.(Hyattsville: National Center for Health Statistics, 1991), p. 3.

People of both sexes and all races in the U.S. live longer now than in the last century. The U.S. population pyramid for 1980 is characteristically tall and elongated, typical of populations with low mortality rates and larger proportions of the population surviving to older ages. 11

Demographic trends in mortality statistics show that mortality is highest at the extremes of ages while death rates for females are lower than those for males at all ages. 12 In infancy, boys are more vulnerable to some birth hazards, infection and injuries. In early and middle adult life, accidents and violence account for a high male death rate while in advanced ages more "wear and tear" takes a higher toll on men than women.13 In assessing potential health

11 U.S. Bureau of the Census, Statistical Abstract of the United States: 1990. 110th edition. (Washington, D.C., 1990). Table 13 Total Population, by Age and Sex: 1960 to 1988, p. 13. See also: Williams, Demographic Analysis, p. 15.

12 williams, Demographic Analysis, p. 76.

13 williams, Demographic Analysis, p. 76. 
benefits to be had by overland migration and resettlement, the following discussion will explore some of the underlying theories of mortality statistics as they applied to nineteenth century oregon in order to assess how those in the Pacific Northwest compared to the rest of the nation.

In 1,000 of population.

75>

$65-74$ and

$60-64$ 15

55.59 Bis.

50.54 is.

45.49 15.

$40-44$ W

35.39 Fin

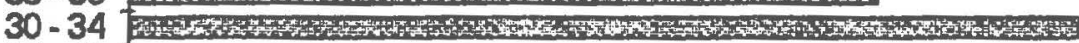

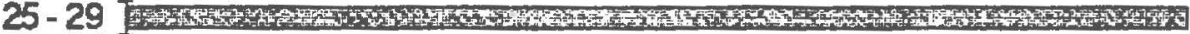

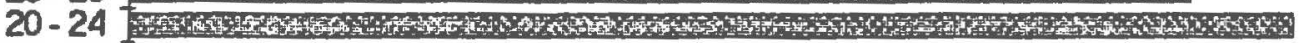

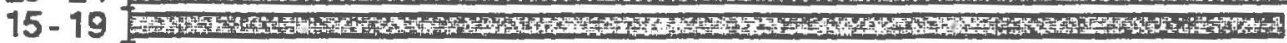

$10-14$ H.

5.9 F

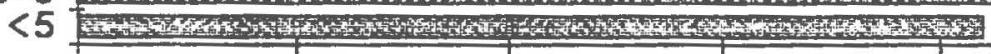

$\begin{array}{lllllll}0 & 2000 & 4000 & 6000 & 8000 & 10000 & 12000\end{array}$

Figure 22. 1980 U.S. male population by age.

In 1.000 of population

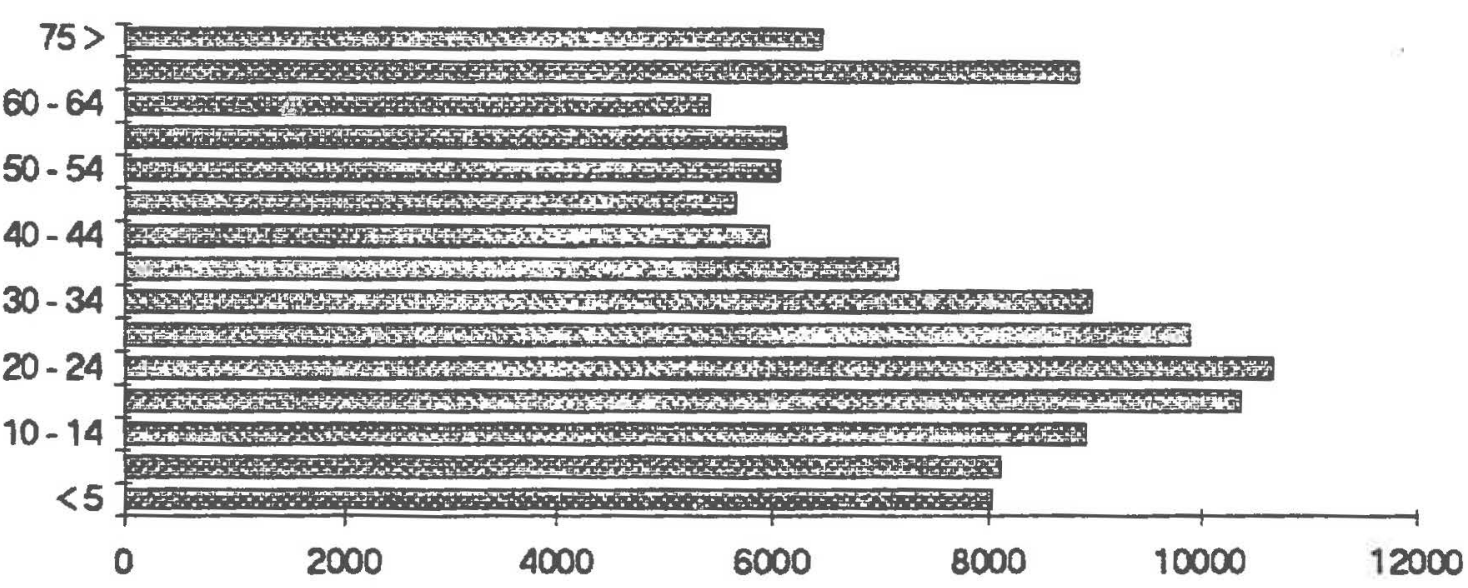

Pigure 23. 1980 U.S. female population by age. 
Between 1860 and 1870, the population of the U.S. increased 22.7\%. The crude death rates also increased during this decade. The Eighth Census in 1860 showed the crude male death rate was 12.91; adjusted for accidents, it was 12.03 .14 Nationally in 1870 , the crude male death rate was 13.37 per 1,000 of population, while the crude male death rate from disease was 12.47 .15 Female death rates were lower than those of men. In 1860 , the crude female death rate was 12.10; adjusted for accidents, it was 11.72 .16 In 1870 , the national crude female death rates rose slightly to 12.15; adjusted for accidents, it was 11.87 .17

\section{Oregon's Mortality Statistics}

Oregon's population in 1860 boasted crude deaths rates among the lowest three reporting districts in the nation. For Oregon women, the crude death rate was 5.8 per 1000 of population; adjusted for accidents, the rate was 5.61. Oregon men boasted even better statistics. Their crude death rate was 4.12, while adjusted for

${ }^{14}$ In this context, accidents include deaths from suicide, homicide and executions in addition to drowning and other types of accidental death.

15 Death rates are traditionally presented as rates per 1000 of population. Thus the crude death rate is calculated by dividing the total number of deaths by the population at risk and multiplying by 1000. All mortality and death rates cited in this paper are expressed as such unless otherwise noted.

${ }^{16}$ Kennedy, Preliminary Report on 8th Census 1860. Table VI, Table of Mortality in the United States., pp. 140-141.

17 Ninth Census. Table V, Mortality of the United States, pp. 12-195. 
accidents, it was 3.55 .18 Unlike the national numbers, Oregon's female mortality rate exceeded that of their male counterparts. In 1860, the ratio of male deaths to female deaths in Oregon was 1.07. However, when adjusted for accidents the crude death rate is 0.96 , so that while sixty percent of Oregon's population was male, they died proportionally less frequently than women did.

In 1860 , only $27.5 \%$ (or 11 of 40 ) reporting districts showed a female mortality rate that exceeded the male mortality rate. These eleven are geographically diverse, including New England, The South, The Old Northwest, the Middle West, and the West so that general similarities between populations and death rates are difficult to evaluate.

\section{Mortality by Age Groups In 1860}

Oregon's crude male mortality rate in 1860 was consistently among the lowest five reporting districts in each age group and seldom approached the national averages for that age groups.

Oregon's crude female mortality by age groups reflect similarities to that of the males. In general, Oregon's women ranked among the lowest five reporting districts with the exception of the age groups $10-19$ and $20-29$.

${ }^{18}$ Kennedy, Preliminary Report on 8 th Census 1860. Table VI, Table of Mortality, distinguished by Sex the number of Deaths in the United States., pp. 142-161. 


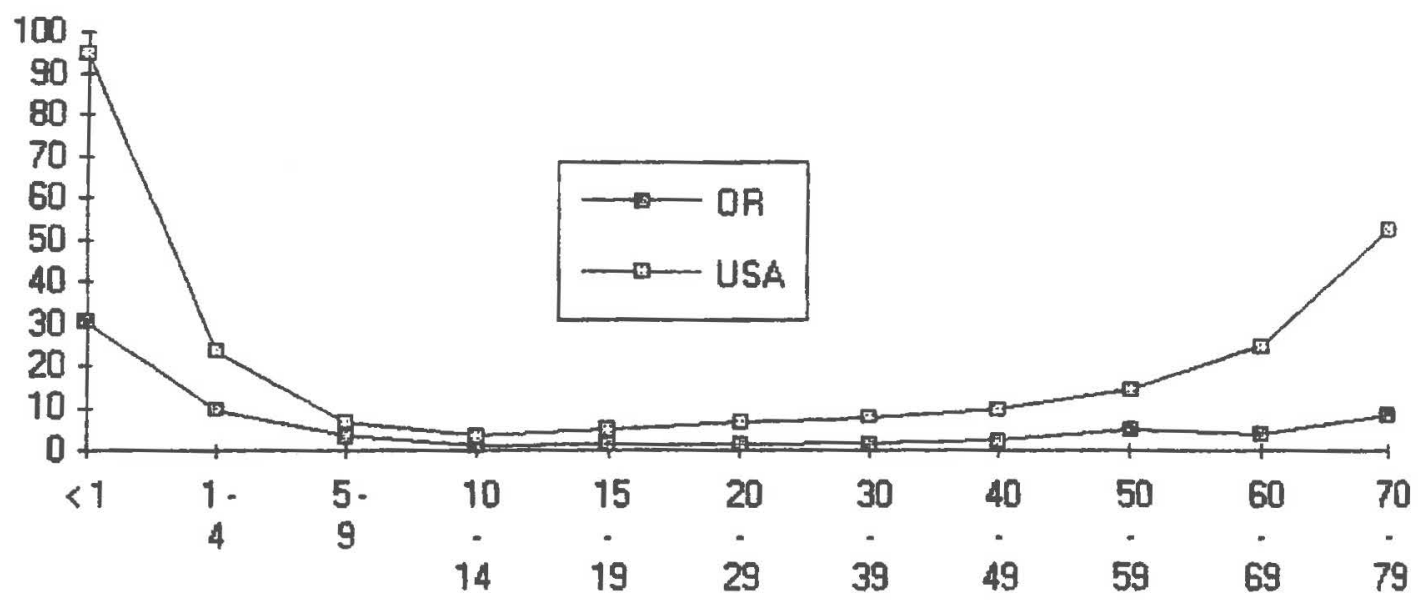

Figure 24. 1860 crude male death rates per 1,000 of population by age.

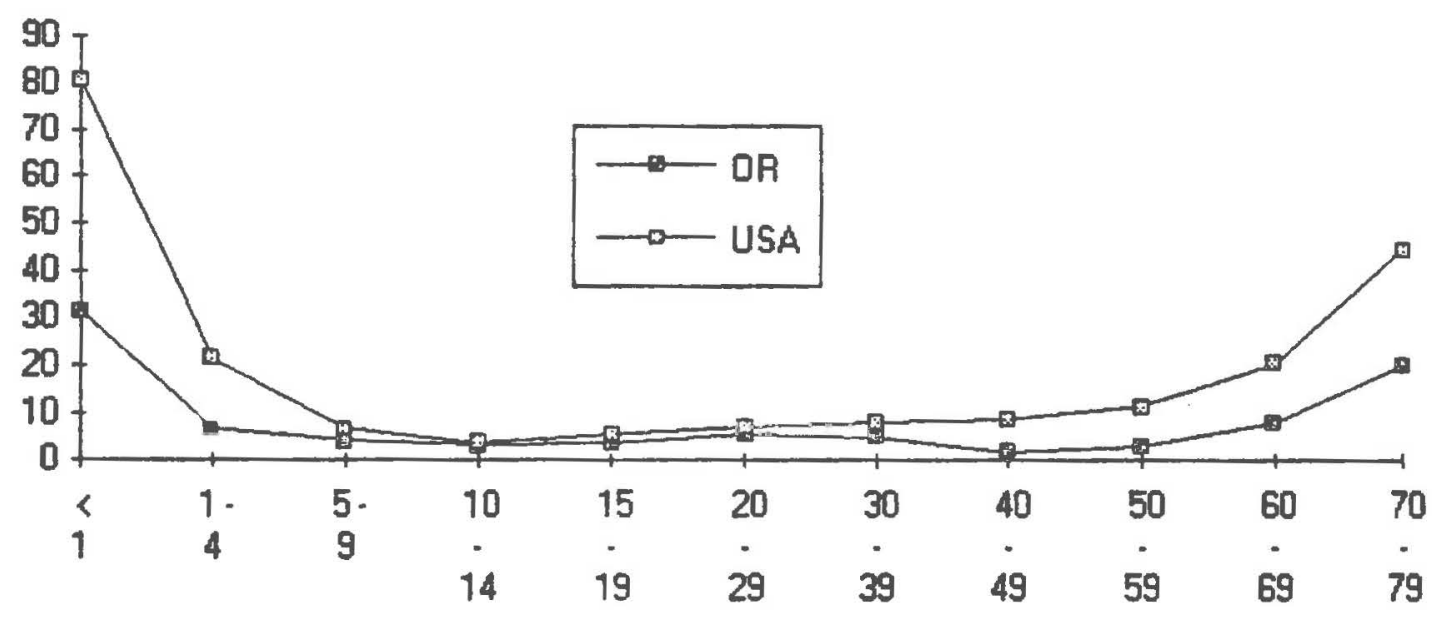

Figure 25. 1860 crude female death rates per 1,000 of population by age.

In the age group 10-14 Oregon women ranked twelfth lowest with a death rate of 3.18 as compared to the national average of 3.73 . For cohort 15-19, Oregon ranked sixth with a crude female death rate of 3.67 as compared to the national rate of 5.43 .

In general, childbearing years took their toll on American women. Table II illustrates this phenomena. The majority of reporting 
districts by age cohorts reported a crude male mortality rate that generally exceeded the crude female mortality rate, with the exception of the childbearing years, which were especially deadly for women.

TABLE II

NUMBER OF REPORTING DISTRICTS BY AGE WHERE CRUDE FEMALE DEATH RATES EXCEEDED CRUDE MALE DEATH RATES

$\begin{array}{ccc}\text { Age group } & 1860 & 1870 \\ & \text { OUT OF 40 } & \text { OUT OF } 47 \\ \text { DISTRICTS } & \text { DISTRICTS } \\ <1 & 4 & 4 \\ 1-4 & 5 & 8 \\ 5-9 & 19 & 17 \\ 10-14 & 29 & 21 \\ 15-19 & 28 & 37 \\ 20-29 & 28 & 29 \\ 30-39 & 31 & 29 \\ 40-49 & 13 & 17 \\ 50-59 & 4 & 6 \\ 60-69 & 6 & 2 \\ 70-79 & 6 & 8 \\ 80-89 & 6 & 10\end{array}$

Mortality by Age Groups in 1870

In 1870 , Oregon again reported crude death rates that ranked among the lowest in the United States. Ranking third overall, Oregon's crude female death rate was 7.54 per 1,000 of population, adjusted for accidents, the rate was 7.33. Oregon men ranked second with a crude death rate of 6.34 , adjusted for accidents, the rate was 5.46.19 As had been the case in the 1860 census, Oregon's crude female death rate exceeded the crude male death rate. The ratio of

${ }^{19}$ Ninth Census. Table. V, Mortality of State of Oregon, pp. 152155. 
male deaths to female deaths was 1.18, adjusted for accidents, the ratio was 1.05 . Thus, Oregon males who made up $58 \%$ of the population still died proportionally less frequently than did women.

By age group, Oregon's crude male death rates were generally among the lowest in the nation and never exceeded the national averages.

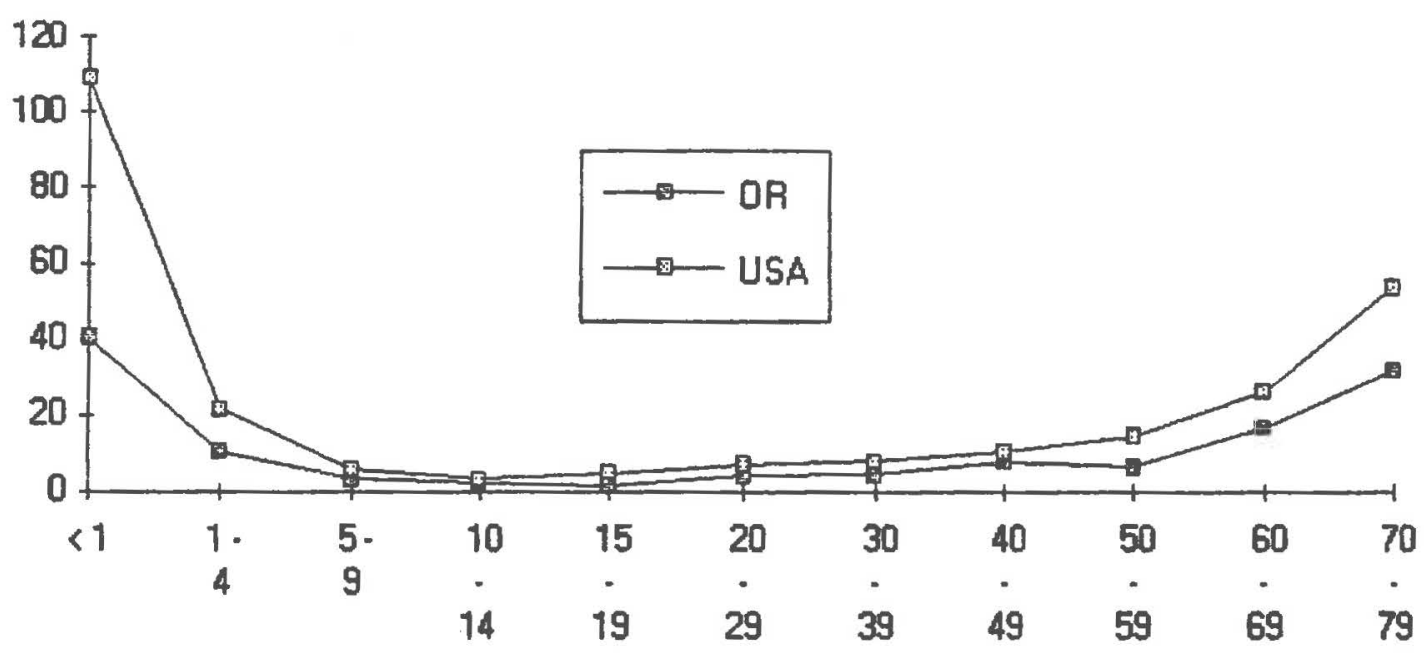

Figure 26. 1870 crude male death rates per 1,000 of population by age.

Oregon's crude female death rates were generally lower than the national averages, especially at the extremes of age. However the child-bearing years put Oregon's women at or above the national averages. In the age group 20-29, Oregon reported a crude female death rate of 7.24 which almost matched the national average of 7.26 . The age group 30-39 reversed this trend slightly, showing a crude death rate of 5.36 well below the national average of 8.23 . On the other hand, in the age cohort 40-49, Oregon women exceeded the national average of 8.79 , showing a crude female death rate of 9.74 . 


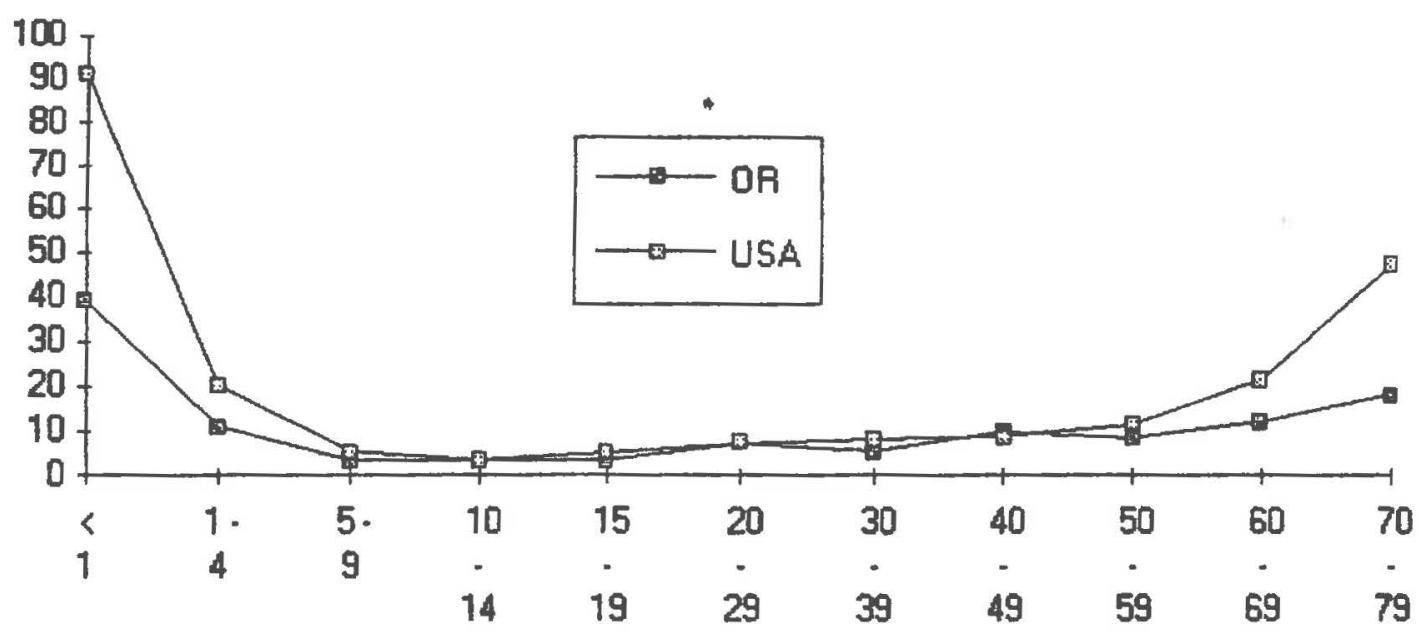

Figure 27. 1870 crude female death rates per 1,000 of population by age.

For a number of reasons, people in the Pacific Northwest exhibited lower death rates than other regions of the country. The youthful age structure of its population accounts for part of it. The ordeal of the overland trail was not something older or sick individuals often survived, as even those of robust health succumbed to trail diseases, especially the dreaded cholera. Thus, those in generally good health, who were lucky enough to skirt epidemic diseases, were the ones who eventually settled in Oregon.

The area was not subject to the same malaria conditions the settlers sought to escape, although the disease was endemic to some low-lying lands. The population tended to settle in a dispersed pattern and did not share water supplies. Thus, contagious diseases required the development of social institutions, such as schools, before they began to take their toll in the newly settled region. In the river valleys of the Pacific Northwest, where most of the 
immigrants resided, the climate was mild but wet. It was not an ideal health climate, but it was an experience that promised better health conditions than the lands around the Mississippi and Ohio rivers. 
St. Joseph Hospital underwent fundamental changes from its inception in 1858 through 1879. The changes involved the philosophy of the organization, medical technology and its application, and the perceived needs of the sisters in fulfilling their role in the community. The pulse of missionary work, at first the life blood of the hospital, over the course of the first two decades became secondary to medical treatment. The growth of the community and the addition of hospital competition influenced this change, while the sisters themselves initiated and implemented policies that furthered the growth of the hospital.

GOALS, OBSTACLES, AND OBSERVATIONS

\section{Missionary Role}

The sisters viewed their hospital as a special place: a unique sphere especially tuned to accommodate God's work. The hospital chronicles often echoed such sentiments. "The numerous conversions that have occurred here are proof that this hospital is the good God's work...In our humble little mission a sublime work was beginning, a future of heavenly favors lay ahead." 1 The hospital was 
more than a care facility open to all, it was a sanctuary, "a port of safety open to poor sinners, a tower of David where all who suffer will find shelter and protection." 2 In founding the hospital, the sisters thought only of the glory of God and the alleviation of the pains of the sick, both spiritually and physically, and according to their written accounts, gave little thought toward the worldly means needed to carry on day-to-day operations. ${ }^{3}$ They sought their rewards in terms of "spiritual consolations" and conversions where "a soul was snatched from the devil by the grace of baptism, [or] a negligent Catholic returned to his duties to God."4 To serve the spiritual needs of the patient was intimately involved in the charter of the sisters since "it is only right...that a Sister of Charity suffer to snatch souls from the devil." 5

During the early days of the hospital, the sisters did not foresee the needs and demands that would later be placed on the institution. "We never dreamed at the time in our humble obscurity that we would later be working on a much bigger scale." 6 They continued in their belief in the righteousness of their work with the poor and sick despite difficulties. The sisters sought some validation of their efforts in terms of their patients' acceptance of Catholicism.

\footnotetext{
${ }^{2}$ Lenz, "Chronicles of St. Joseph Hospital." p. 3.

${ }^{3}$ Lenz, "Chronicles of St. Joseph Hospital." p. 4.

${ }^{4}$ Lenz, "Chronicles of St. Joseph Hospital." p. 5.

${ }^{5}$ Lenz, "Chronicles of St. Joseph Hospital." p. 14.

${ }^{6}$ Lenz, "Chronicles of St. Joseph Hospital." p. 7.
} 
In the years 1860-1861, they saw indications of God's blessings upon their work. "We had many visible signs of the Lord's protection in our work. Our poor little hospital had many difficulties, but its blessings were abundant too as we saw them in conversions." 7 They did not limit their work to the Catholic community and their doors were opened to those of very limited means:

\begin{abstract}
No poor person was turned away. We always found a place in the humble and narrow shelter. Often ungrateful Protestants or bad Catholics were kept month after month without a cent paid, for the sole purpose of converting them or making them a little better. ${ }^{8}$
\end{abstract}

Yet they recognized that their chosen path was not an easy one.

\title{
Underlying Tensions
}

The sisters were forced, upon occasion, to face religious tensions in their hospital work. Some Protestant patients resisted their missionary activities. For example, in 1860-1861, a man suffering severely from asthma entered the care of the sisters. "His suffering and prejudices made it difficult for us to save him. Sister John redoubled her attentiveness to this heretic, who did not want to hear her speak of religion."9 During a violent asthma attack, Sister John pleaded with him to ask for spiritual help. He did so, was baptized, and died a short time later. ${ }^{10}$ Stories such as these

\footnotetext{
7 Lenz, "Chronicles of St. Joseph Hospital." p. 7.

${ }^{8}$ Lenz, "Chronicles of St. Joseph Hospital.". p. 8.

${ }^{9}$ Lenz, "Chronicles of St. Joseph Hospital." p. 8.

${ }^{10}$ Lenz, "Chronicles of St. Joseph Hospital." p. 8.
} 
were inspirational, and motivated the sisters to carry forward their work. Wherever they could overcome the prejudices of Protestants and bring them back to the fold, their mission was fulfilled. They were determined to overcome any obstacles that held back their missionary activities. But some groups were especially obstinate in resisting the sisters' efforts. "We have had many Protestants of all denominations, conversions of many sinners, Indians who have given up superstition. But Freemasons need extraordinary grace and many do not repent." 11

According to the chronicles, the sisters found the Preemasons a most troubling element in their missionary endeavors. Sometimes they succeeded in their efforts. "Eight months before he died he became a Catholic. Obstacles to his conversion were his weakness, his prejudices and the continual arguments of his friends and Freemasons."12 The sisters recognized that the Freemasons were antagonistic toward their undertaking and recounted several stories, such as the one in February 1872, that described a patient admitted to the hospital who was denied their religious counsel because his brother was a high-ranking Freemason. "His brother forbade us to speak to him of religion or death, or else he would immediately take him away."13 on another occasion, the sisters believed that a Preemason "out of human respect resisted grace...he kept saying he

${ }^{11}$ Lenz, "Chronicles of St. Joseph Hospital." p. 18.

${ }^{12}$ Lenz, "Chronicles of St. Joseph Hospital." p. 14.

${ }^{13}$ Lenz, "Chronicles of St. Joseph Hospital." p. 19. 
wanted to go to confession...the masons stayed near him day and night...he was in horrible condition...yet he died resisting grace." 14 In true missionary form, they knew it was an uphill battle but were resolute in the pursuit of their goals.

\section{Patients and Patience}

While the sisters were dedicated and determined in their work, they did upon occasion note situations that tried even their patience. For example, when Mrs. Domis Blanchet arrived in 1864 with her two sick children, the chronicles recorded that, "Among ourselves we must say that she is unreasonableness itself. Finally, thank God, she left us well-satisfied."15 At times the patients pushed the sisters' patience and "it took the virtue of an angel to cope with them."16 In January 1877 an eighty year old man joined the mission community as a boarder. In return for their care, he gave the sisters $\$ 3,000$. The sisters amusingly noted that "he became celebrated for his exacting demands on us. Among ourselves we would say, 'The money has been dearly earned by us.' "17 As for the number of children under their care, the sisters noted "they

${ }^{14}$ Lenz, "Chronicles of St. Joseph Hospital." p. 24.

${ }^{15}$ Lenz, "Chronicles of St. Joseph Hospital." p. 10.

${ }^{16}$ Lenz, "Chronicles of St. Joseph Hospital." p. 21.

${ }^{17}$ Lenz, "Chronicles of St. Joseph Hospital." p. 22. 
give us a lot of work and sacrifice. It takes patience and courage to care for them." 18

\section{Good Deaths}

The sisters exhibited a theological view of death that mirrored their evaluation of the patient's ability to face departure from this world. They recorded sentiments such as "he died the death of a saint," "he died like an angel," or in the case of John Bryan, a thirty-five-year-old man who experienced a great deal of pain prior to his demise, "he died a true Christian death."19 While the qualities of angels, saints and 'true Christians' are subjective, the sisters seemed to take note and appreciate those who, in their estimation, bore their sufferings in an appropriate manner.

\section{Shortage of Patients}

Upon occasion the sisters worried about a shortage of patients to fill their hospital beds.

At the beginning of 1869 we had few patients from outside. For almost three months only one or two entered. The rest were children from the college or the orphanage. The sisters were discouraged and feared to see their dearest work disappear. Pather Mantz, the pastor, who was interested in the hospital and who in his devotedness to the patients converted many, promised to say mass for more patients. On the same day a patient arrived, and several days later Patrick Hickery...came in. 20

\footnotetext{
${ }^{18}$ Lenz, "Chronicles of St. Joseph Hospital." p. 25. ${ }^{19}$ Lenz, "Chronicles of St. Joseph Hospital." pp. 5, 7, 8. ${ }^{20}$ Lenz, "Chronicles of St. Joseph Hospital." p. 16.
} 
The 1875 opening of two new hospitals in Portland was noted by the sisters, who despite founding one of the institutions themselves, viewed them as competing organizations. ${ }^{21}$ In 1876-1877, the chronicles noted that "we had few patients from the outside, but we had the school children."22 The sisters' observations, substantiated by the patient register, revealed that after reaching an all-time high of 141 patients in 1873, the number of patients received fell to 85 in 1876, 68 in 1877 and a decade low of 38 in 1878, the year that fire destroyed the hospital. However, by 1879 the trend was reversing with 124 patients admitted, and in the next year 171 patients were received.

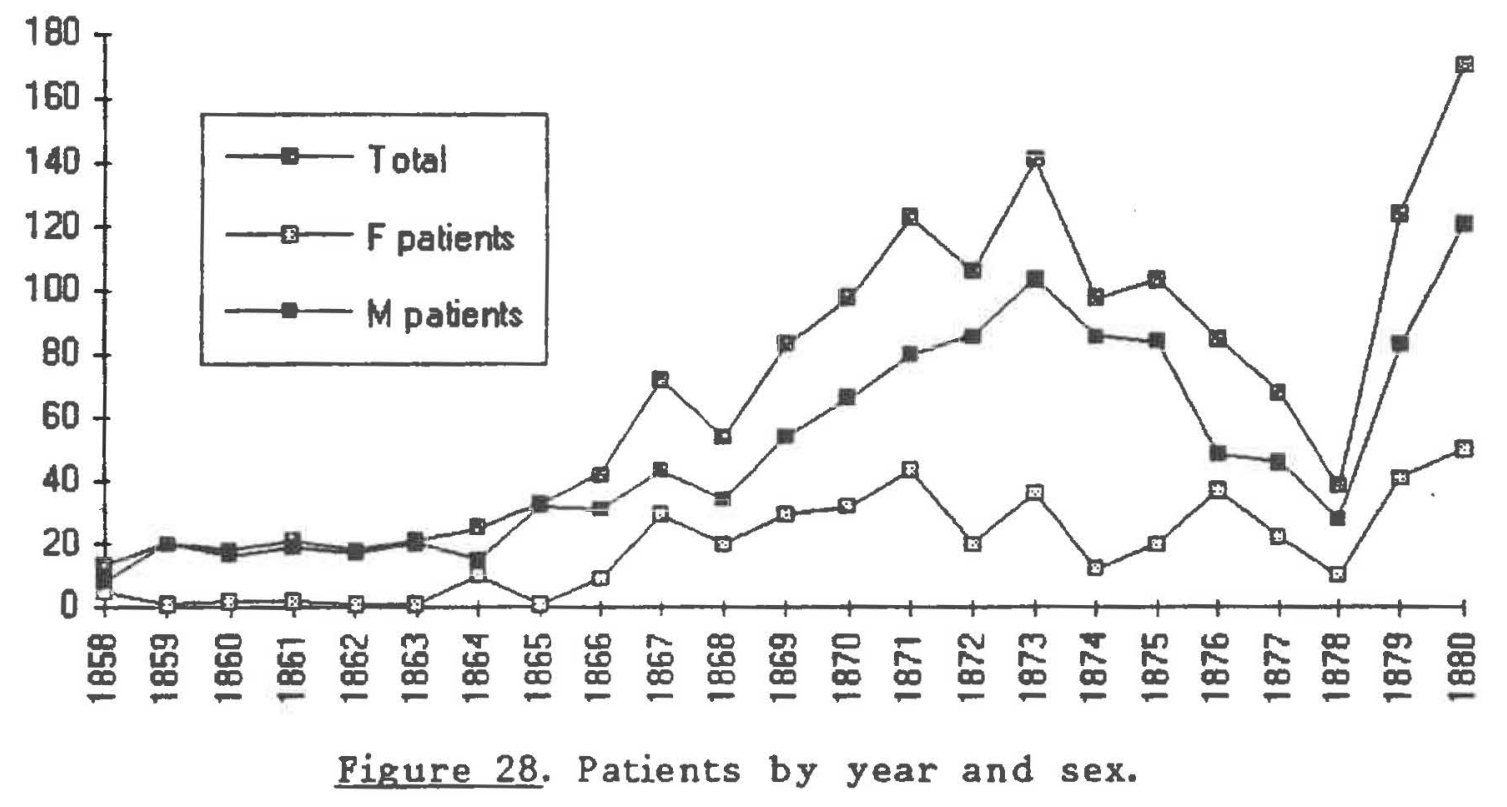

${ }^{21}$ Lenz, "Chronicles of St. Joseph Hospital." p. 21.

22Lenz, "Chronicles of St. Joseph Hospital." p. 22. 
THE ROAD TO PROFESSIONALIZATION

In 1864-1865, the hospital chronicles began to reveal the inadequacies the sisters found in their institution and the personal sacrifices associated with the care of the sick.

This is not surprising when you recall at this time we were not organized to run hospitals. We could not afford to pay a night nurse...our first room for the sick was beside the bakery...on baking days you had to wait until the oven was empty to serve the meals of our patients...in the midst of these daily inconveniences and of the difficulty of caring for the dying in so little space, the good God blessed our work. 23

From 1858 to 1865 , the chronicles conspicuously lack any reference to the doctors who undoubtedly worked there. However, beginning in 1865, subtle changes in the operations and personnel set the hospital toward a more professionalized outlook in terms of health care. During this year, the sisters began to record diagnosis information in the patient register. Such information demonstrated an association of trained medical personnel operating within the institution, although undoubtedly the sisters as well as any physician could ascertain that a particular patient was suffering from an obvious problem, such as a gun shot wound or a crushed limb. In 1865-66, the chronicles reveal the presence of physicians as active participants in the care of the patients. 24

${ }^{23}$ Lenz, "Chronicles of St. Joseph Hospital." p. 10.

${ }^{24}$ Lenz, "Chronicles of St. Joseph Hospital." p. 12. The chronicles recount a suicide attempt by one of the patients using opium that "the doctor prescribed." 
In 1866, after they had lost the contract with Washington Territory for the care of the insane, the building formerly used to house the mental patients was dedicated to the hospital and occupied in september of that same year. The new facility was a great improvement in terms of space and allowed the sisters to expand their operations. Following these changes, expansion plans or repair efforts began to appear in the hospital chronicles reflecting the sisters' attention to the worldly needs of a growing concern. For example, when the sisters upgraded their operations in 1870 , the chronicles recorded:

The increase in patients this year -- from fifteen to twenty a day -- made it necessary to make changes. By the use of a lead pipe water was brought to the second floor of the house... We made an addition to the kitchen and added a second floor there for a laundry. We made a room for the Indians who could be cared for with other patients only with difficulty. We added a bathroom, an operating room, and a room for convalescents called a smoking room. The operating room had especially become indispensable because of the frequent amputations we had. Besides this[,] other operations often required the use of chloroform, and hence a private room. 25

They also initiated a program to train additional nursing staff. In September 1872 the sisters re-established a novitiate as an addition to the hospital "so that the novices could, at the same time, be formed as religious and in the care of the sick."26

${ }^{25}$ Lenz, "Chronicles of St. Joseph Hospital." p. 17. ${ }^{26}$ Lenz, "Chronicles of St. Joseph Hospital." p. 19. 
Establishment of a Pharmacy

Prior to the years 1865-66, the chronicles mentioned only in passing that "prescriptions [were] given."27 This changed when the sisters dedicated resources to a pharmacy. In 1865-1866, "Sister Rose Marie came to fill the pharmacy prescriptions" and contributed toward the trend of expanding operations underway at the hospital. 28 While the pharmacy was not central to what the sisters viewed as the crucial elements of their hospital, the chronicles from time to time mentioned that "Sister Peter Baptist [was] in charge of the pharmacy" or that "Sister Ethelbert took the pharmacy under the direction of Sister Peter Claver." 29 Using formulas from the Materia Medica text and their personal knowledge, the sisters measured and mixed the compounds prescribed by either themselves or the doctors and administered them to the hospital patients.

After the hospital was destroyed by fire in september 1878, the sisters immediately launched efforts to rebuild it. The new structure was erected on the same site as had been the other, and included a "48-by-18 foot extension in the back." 30 The expansion was well utilized as the number of patients admitted to the hospital showed an upward trend after the mid-decade decline.

\footnotetext{
27 Lenz, "Chronicles of St. Joseph Hospital." p. 8.

${ }^{28}$ Lenz, "Chronicles of St. Joseph Hospital." p. 12.

${ }^{29}$ Lenz, "Chronicles of St. Joseph Hospital." pp. 19, 25.

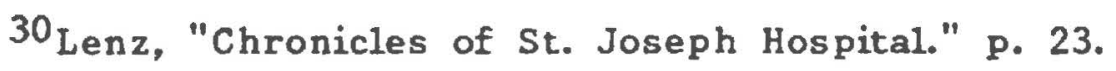


Some New Attitudes

Attitudes toward outbreaks of disease reflected part of St. Joseph's developing professionalized health care orientation. In 18751876, the children of the school and orphanage suffered an outbreak of a contagious skin disease. "In the month of April, the nurses had to have great patience with the terrible plague of scabies. Almost twenty of our children had the contagious disease commonly called 'La Galle."' 31 By 1879-1880 another outbreak of disease reflected a more clinical view of illnesses.

The hospital sisters suffered much fatigue caring for the children from all the departments. Almost all of them caught the measles and whooping cough, some with complications. Some of them also had scarlatina. It was a real epidemic with threat of closing the schools. 32

These changes in attitude toward disease outbreaks revealed a growing realization of causal factors beyond the divine realm.

\section{Expanded Diagnostic Information}

The growth of medical knowledge regarding the diversity of human ailments is suggested by the number and range of diagnoses recorded in the patient register. However, even among members of the same medical sect, agreement on diagnosis was problematic. For example, a detailed discussion and disagreement over the symptoms, cause, and treatment between the diseases 'putrid sore throat' and

\footnotetext{
${ }^{31}$ Lenz, "Chronicles of St. Joseph Hospital." p. 21.

${ }^{32}$ Lenz, "Chronicles of St. Joseph Hospital." p. 24.
} 
diphtheria made front page news in local papers. 33 . During this period, the classification of disease in general was dubious, especially where multiple problems existed. When faced with a similar set of symptoms, many doctors often ascribed their "favorite" disease as causal. 34 The value of diagnosis information in St. Joseph's patient register is that it reflects, in part, the contemporary attitudes and clinical work of the hospital. 35 The actual recording of such information, often lacking in similar patient registers, suggests a more systematic approach to hospital work by the sisters. From 1865 on, the diversity of diagnosis information continually expanded. For example, in 1871 there were 123 patients admitted to the hospital and 29 unique diagnoses rendered. In 1879 , for the 129 patients admitted, the number of unique disease identifications was 42. This suggests at least some awareness of an advancing application of medical terminology and treatment therapy. Not all patients had diagnosis information recorded, but as the following graph indicates, the percentage of such notation was consistently high from 1865 through 1879 and averaged $89 \%$ for the period:

${ }^{33}$ Shaw, R.W. "Letter to the Editor." Oregon Statesman, 22 February 1859, 1:4. Boyle, James W.. "Letter to the Bditor." Oregon Statesman, 9 March 1859, 1:1. Shaw, R.W. "Letter to the Bditor." Oregon Statesman, 22 March 1859, 1:4.

${ }^{34}$ Hollingsworth, Historical Demography, p. 219.

35 Williams, Demographic Analysis, p. 135. 


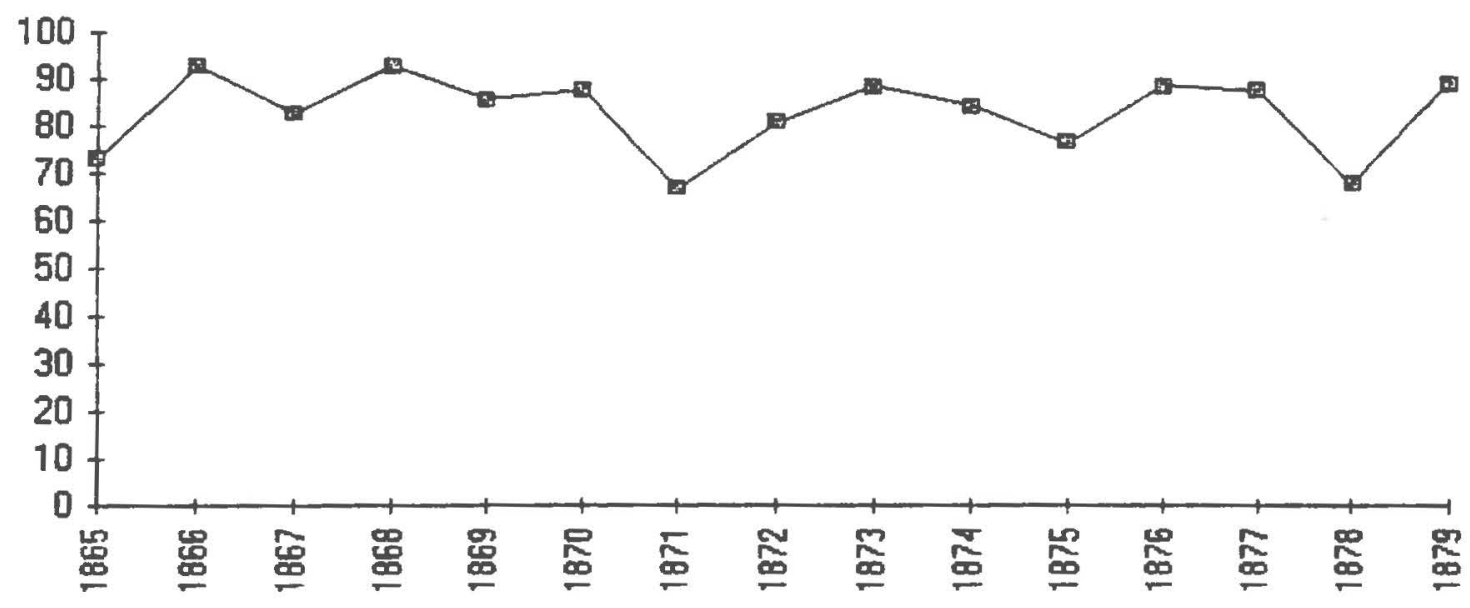

Figure 29. Percentage of patients with diagnosis information.

other evidence supports a growing recognition of clinical progression at the hospital. During the 1860s and early 1870s, a number of patients were diagnosed with 'debility,' which in contemporary terminology described a generalized, nonspecific condition associated with physical weakness. Obviously such a diagnosis could be used to describe any number of specific conditions recognized by physicians in the twentieth century. However, after 1875, the trend of patients diagnosed with debility appeared to decline, suggesting perhaps that other diagnoses provided a better understanding of the patient's ailment. 


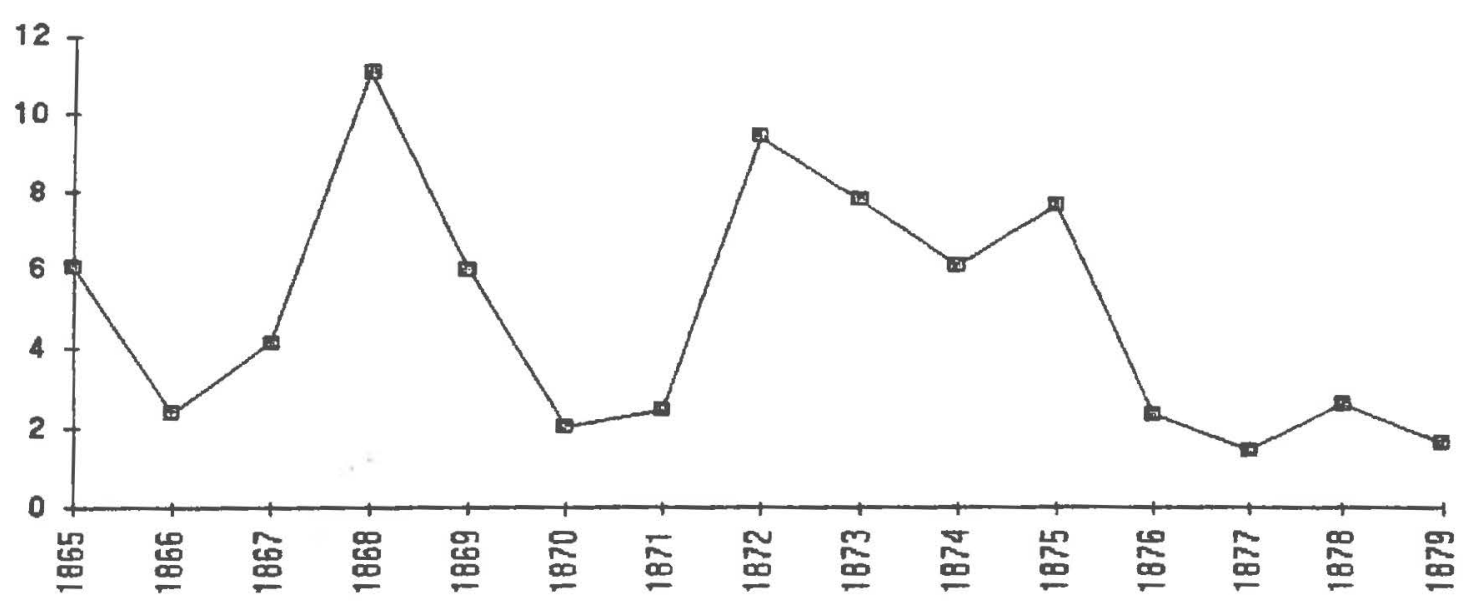

Figure 30. Percentage of patients diagnosed with debility.

The accuracy of all diagnostic information recorded in the patient register is highly suspect by today's medical standards. Nevertheless, the diversity and range of such information suggest at least some regard of medical professionalization and its incorporation into practice at the hospital.

\section{Death Rates}

During the first five years of operation, St. Joseph Hospital experienced a high percentage of patient deaths. In 1858 and 1859, the death rates of admitted patients were $31 \%$ and $30 \%$ respectively. In 1860 , the death rate reached an institutional high of $56 \%$. In 1861 , the death rate dropped to $19 \%$ but rose again in 1862 to $22 \%$. The five year average from 1858 through 1862 reflected the fact that almost one-third of all admitted patients (32\%) died. Thus, the early nineteenth century view of the hospital as an almshouse where the poor and unfortunate came to die holds true in many respects. 36 
Beginning in 1863, the trends in death rates declined with the exception of a peak in 1868 where the death rate again climbed to $17 \%$ and averaged $13 \%$ for the years 1863 through 1866.

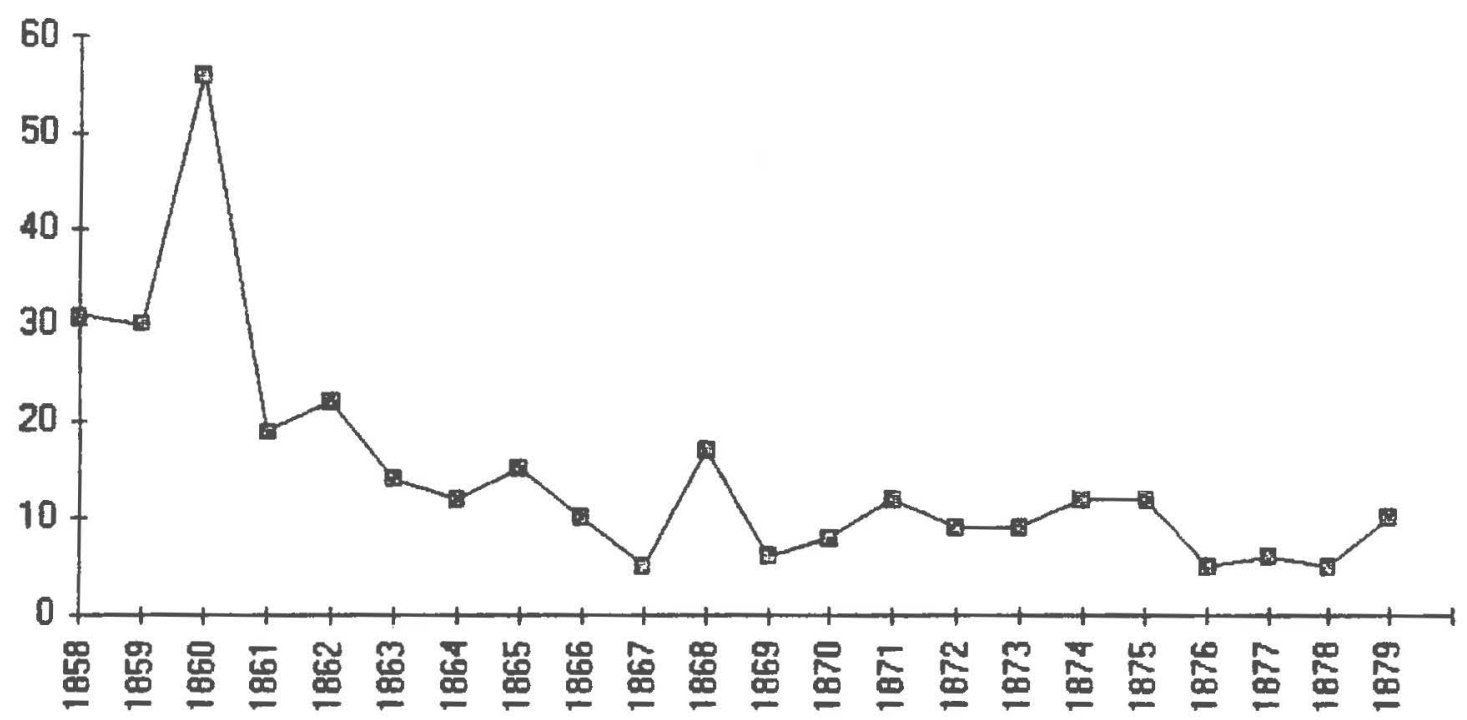

Pigure 31. Percentage of patient deaths by year.

Prom 1869 to 1879 the death rate rose and fell, ranging from $5 \%$ to $12 \%$ and averaging $9 \%$ for the eleven year period. In comparison, Philadelphia General Hospital in 1910 reported a death rate of $12 \%$, which in one historian's estimation, demonstrated that this particular hospital still retained an almshouse stigma. 37

${ }^{37}$ Rosenberg, The Care of Strangers, p. 325. Statistical information for other hospitals of this era is, at best, difficult to procure. Philadelphia General Hospital is used to provide the reader some comparative basis with St. Joseph Hospital. 


\section{Conversions}

As hospital work became professionalized and ascended as a primary force, the missionary vocation, while still essential, became a secondary aspect of the sisters' work. Since 1858, the patient register was used to note baptisms and conversions that occurred at the hospital. During the early years, the percentage of patient conversions was high, in part because the total number of patients was low.

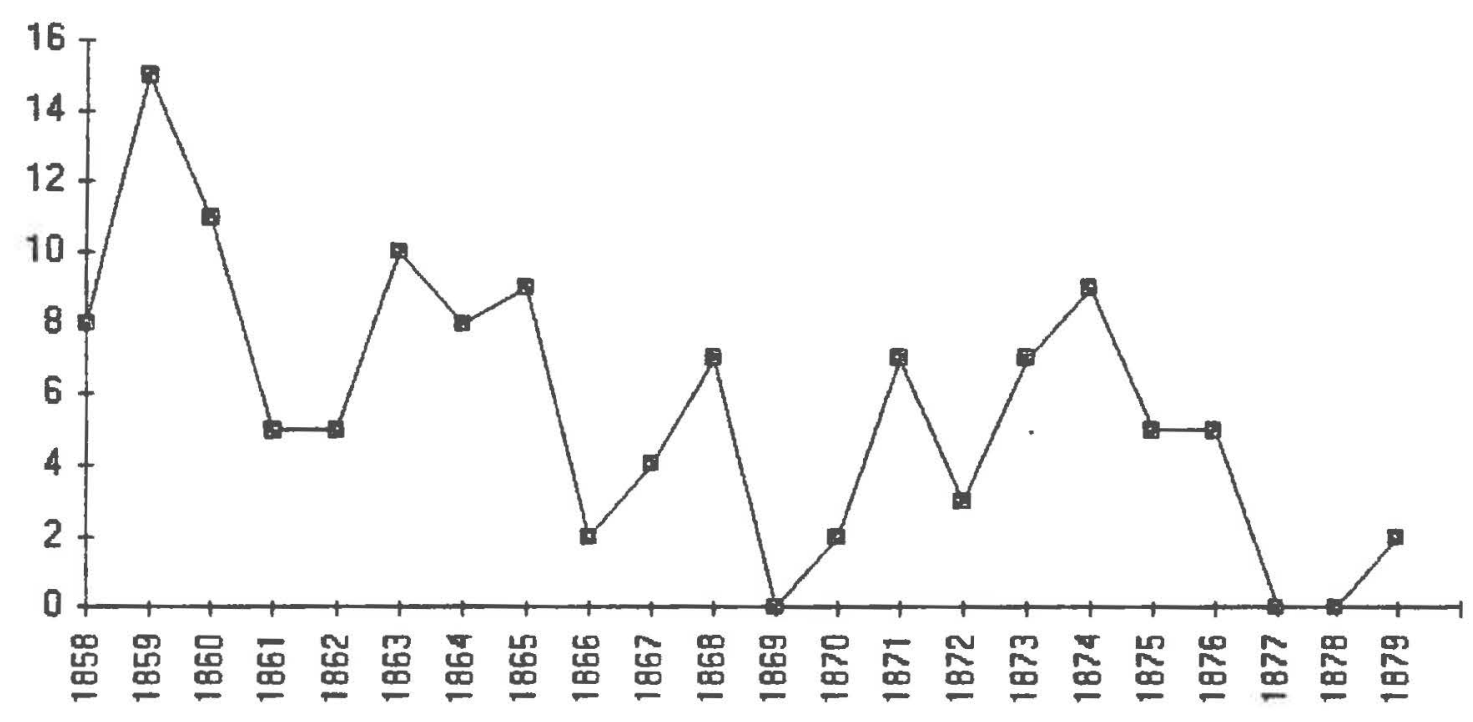

Pigure 32. Percentage of patients converted.

During the 1870s, the percentage of patients converted reached a decade high in 1874 with 9 of 98 patients (almost 10\%) either converted or baptized. However, the latter part of the decade showed the trend falling off despite the low number of patients in 1877 (68) and 1878 (38). Thus, as the hospital moved toward professionalized health care, and in the face of competition for 
patients from other hospitals, the missionary work among the patient population seemed to give way.

However, conversion rates also reflected the needs of the patients. Since many of the early patients came to the hospital as a last resort, they came to face their maker. Fifty percent of patients converted between 1858 and 1879 died in the hospital. In the years 1858, 1859, 1861, 1868 and 1870 one hundred percent of those converted died.

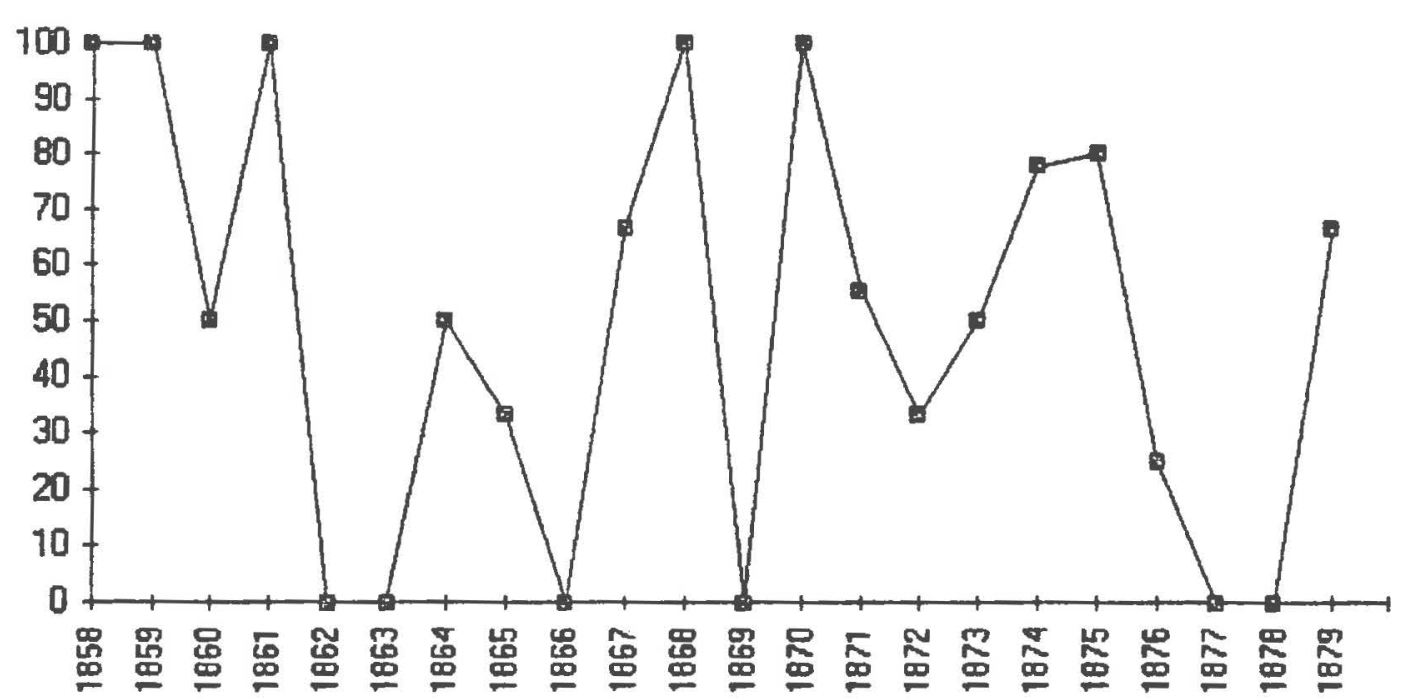

Figure 33. Percentage of patients who converted and died at the hospital.

While it is not possible to doubt or question the sincerity of the patients' new devotion to God, their recognition of mortality undoubtedly paved the road toward their embrace of Catholicism. 


\section{Sex and Age Profiles of Patients}

St. Joseph received a majority of adult patients. Between 1858 and $1879,71 \%$ of all patients admitted to the hospital were older than sixteen years of age. 38 Adult male patients represented the bulk of the patients treated at St. Joseph hospital. Pigure 35 dramatically illustrates this point. From 1858 through 1866, only 32 of 211, or $15 \%$ of the patients received at the hospital were women. From information provided in the patient register, adult women are slightly more difficult to categorize. Historically, the domestic duties of wife and mother did not receive the same professional recognition that other occupations commanded. Thus, women, almost without exception, lacked profession information in the patient register. 39 Often women's ages were not recorded; for some, the country of origin (almost always given for males) was missing. Thus, from a historical standpoint, the adult female patients remain slightly more anonymous than men.

In 1867 , the number of female patients admitted to the hospital began to show an upward trend. These patients were, for the most part, young girls ages 0 - 15; the greater percentage of them were associated with the either the orphanage or the boarding school.

38 For the 1,297 patients listed with age data (between the years 1858 - 1879), 37.6 were between $0-15,877$ were $16-64$ and 44 were older than 64 .

39 Female patients associated with the mission as sisters or support staff were the major exception to this rule. 


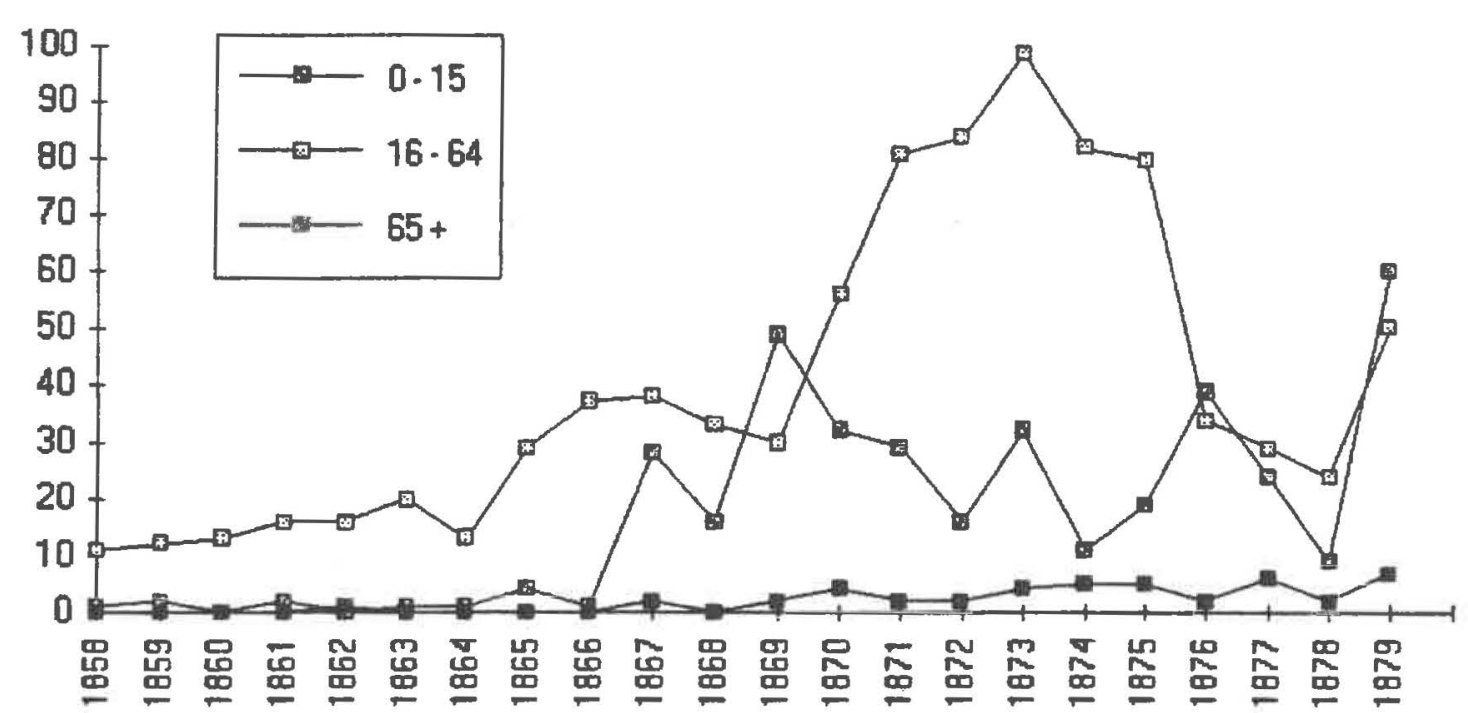

Figure 34. Patients by age group and year.

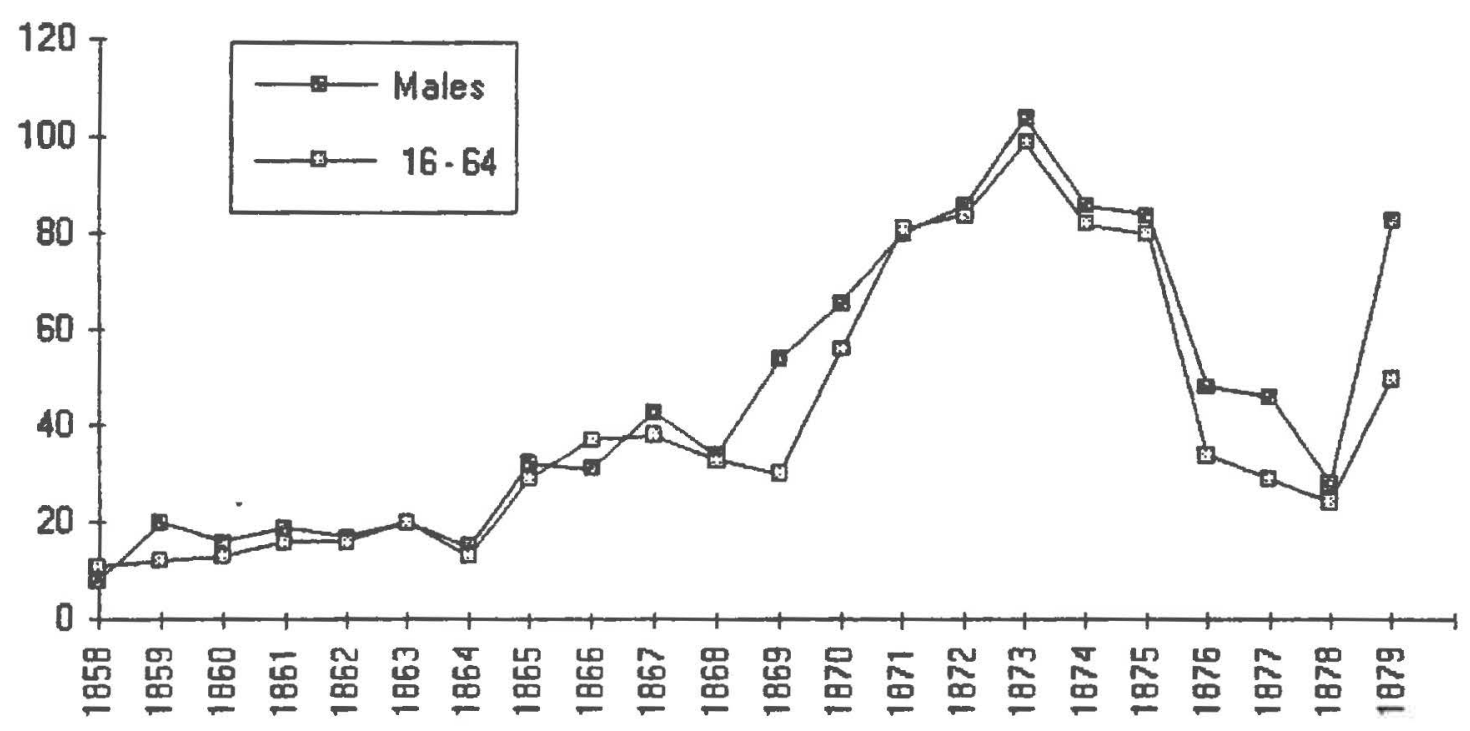

Figure 35. Male patients vs. all adult patients. 


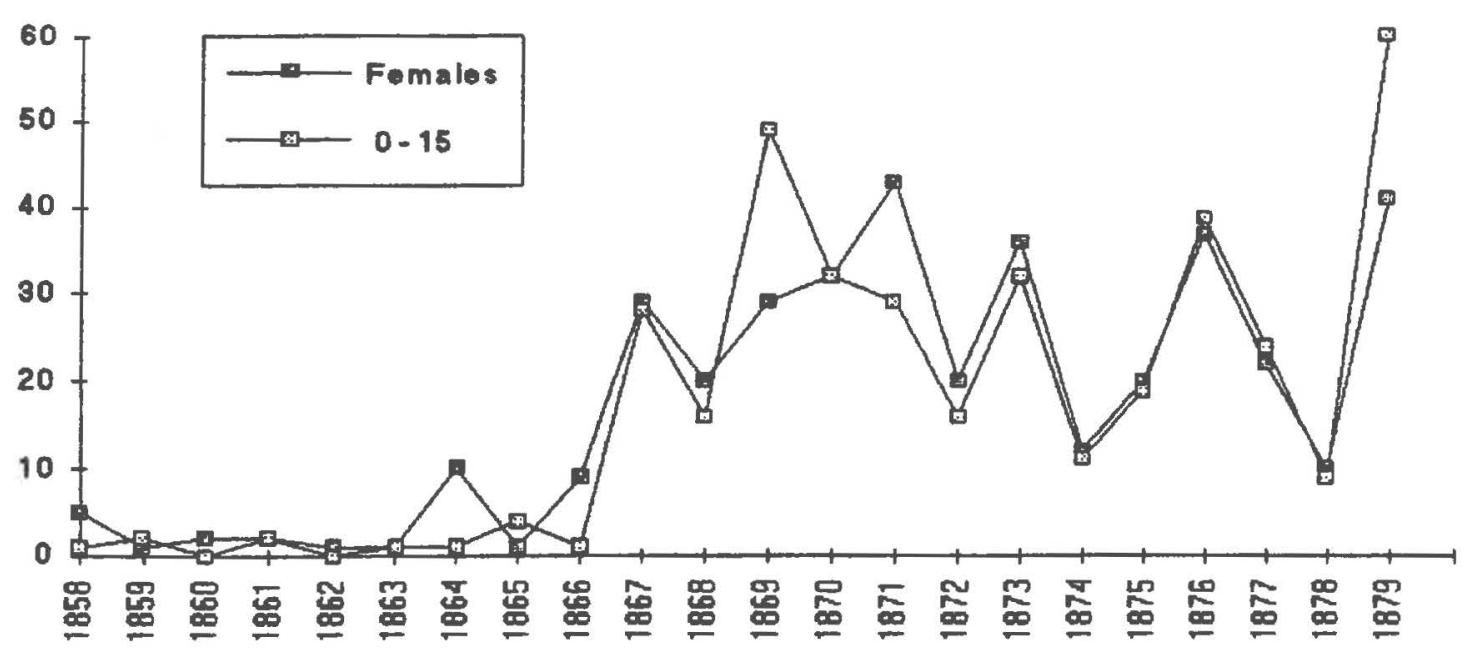

Figure 36. Female patients vs. all patients ages $0-15$.

The correlation between the female patients and the ages of patients under 16 supports the observation that female patients at the hospital were on average younger than their male counterparts. The average ages of both the male and the female patients illustrated in figure 36 adds further support. For the period 1858 through 1879, female patients averaged 18.7 years of age while the male patients averaged 31.7 years of age.

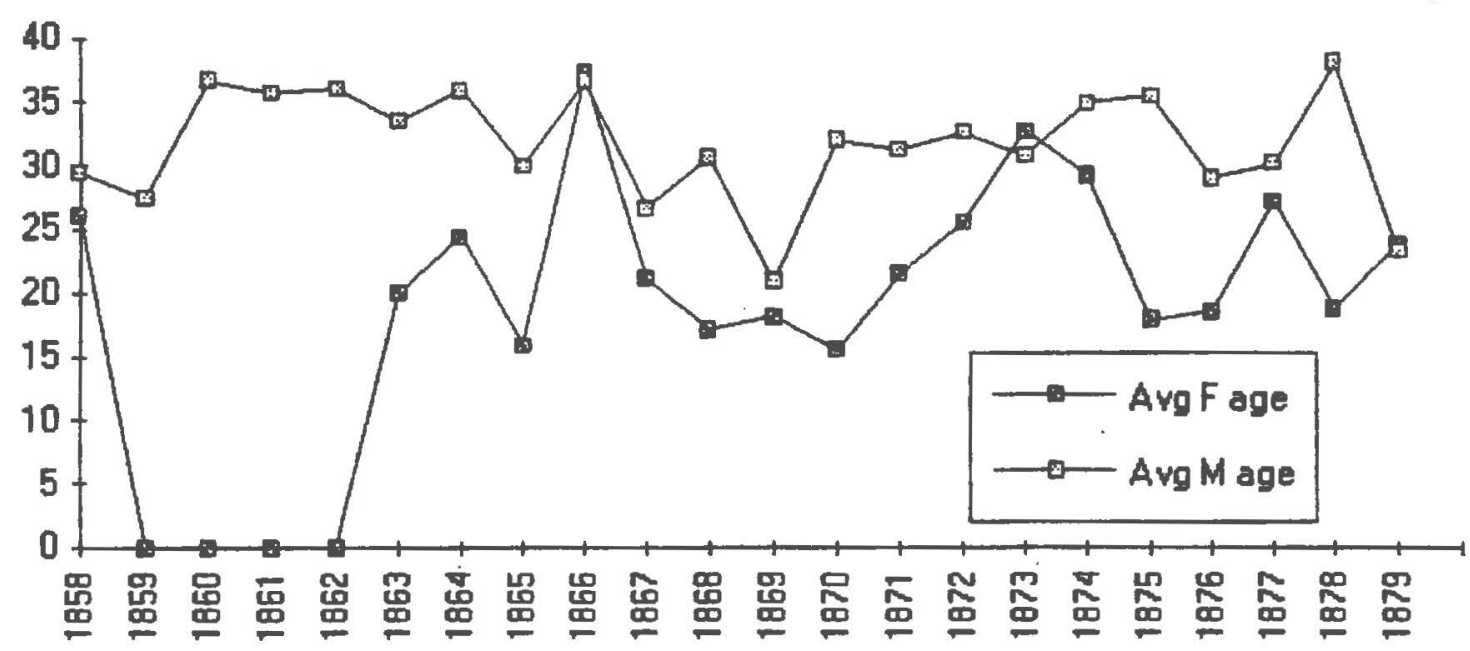

Figure 37. Average ages of patients by year and sex. 
Length of Stay

Female patients tended to have shorter convalescent stays than did their male counterparts. 40 Many factors help explain this phenomena; the age differential, the patient's association with the mission, the severity of the condition which brought the patient to the hospital and the general perceptions of hospitals associated with the era.

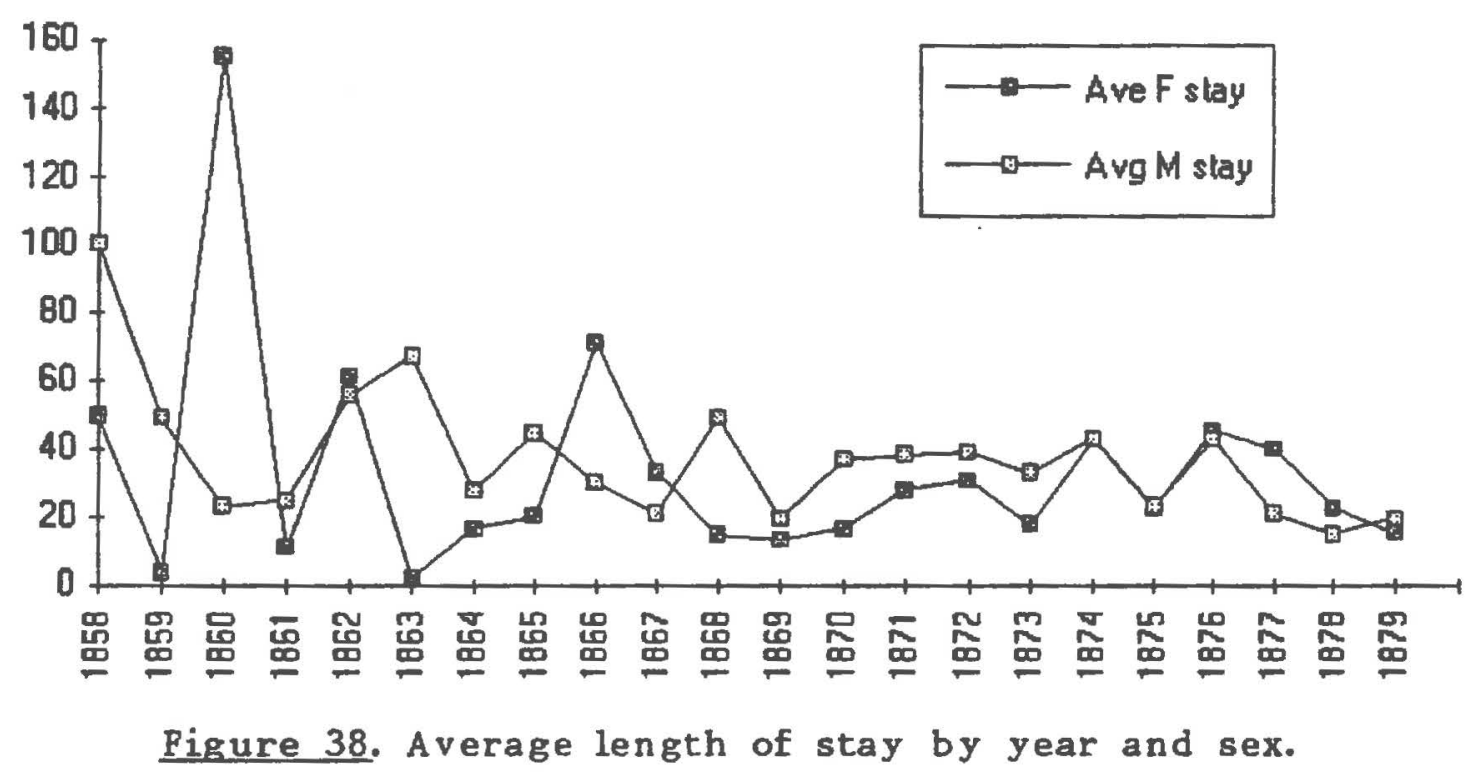

During the 1870s, the trends in the average length of stay for both sexes moved closer together; for male patients it was 31 days, for female patients, 28 days. In comparison, the Philadelphia General Hospital in 1910 recorded an average length of stay of 35 days,

${ }^{40}$ Calculations of the average length of stay were slightly adjusted by eliminating a small number of patients whose stay exceeded one year. For male patients, the number excluded by year: 1859 - 1, 1865 - 1, 1866 - 1,1868 - 1,1871 - 3,1872 - 1, 1879 - 1 . For female patients, the number excluded by year: $1872-2,1873-$ $2,1876-1$. 
independent of sex. 41 Male patients at the Commercial Hospital in Cincinnati had a mean age of 30.7 years and averaged about 17 day stays. 42

Homegrown Patient Base

The percentage of hospital patients that were associated with the mission as orphans, boarders, sisters, support staff or associated with the Holy Angels boys schools was $16 \%$ for the period 1858 through 1879. By a large margin, the children were the bulk of this patient base. As demonstrated in figures 1 and 3 in chapter III, the population at the orphanage and the boarding school throughout most of the 1860 s and 1870 s was steady. In contrast, the percentage of the children as patients shows dramatic peaks and valleys.

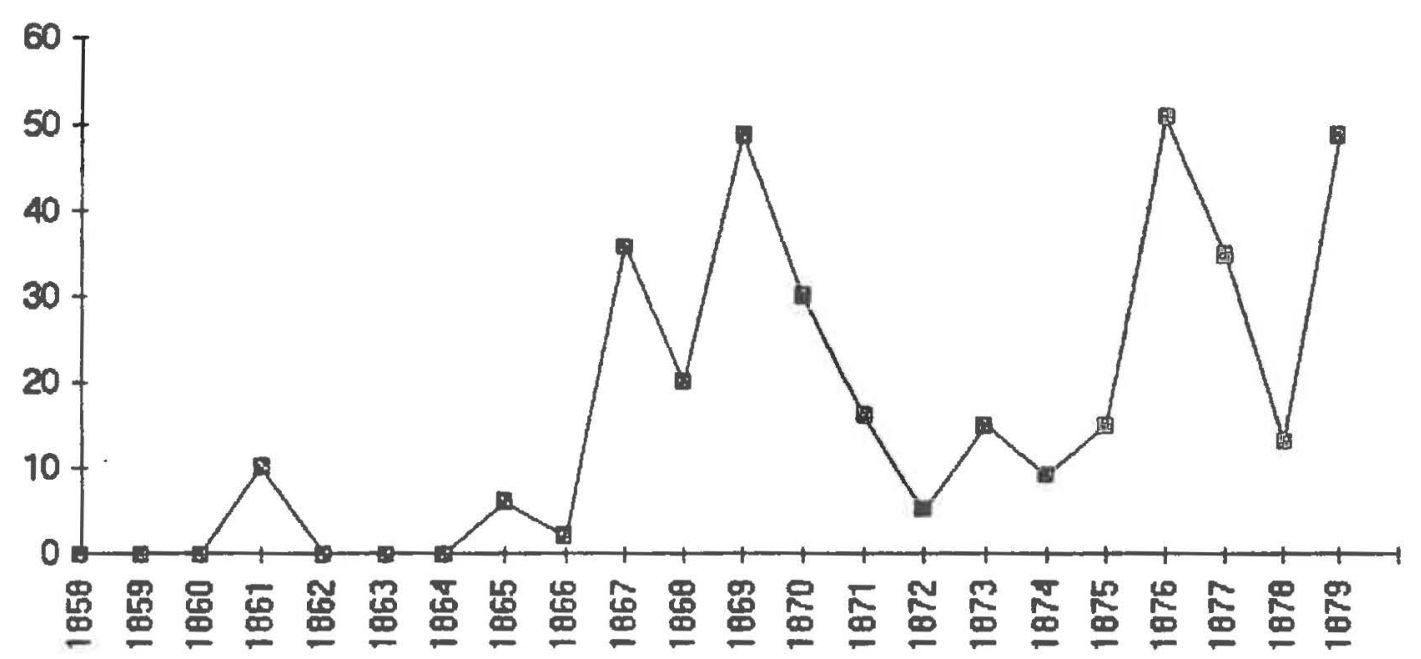

Eigure 39. Percentage of patients associated with the House of Providence by year.

${ }^{41}$ Rosenberg, The Care of Strangers, p. 325.

42 Warner, "Power, Conflict and Identity", p. 944. 
In some cases, outbreaks of contagious diseases among the children account for this situation. For example, the patient register of 1866 reveals that a number of children were diagnosed with eczema. In 1869 , mumps sent many mission children to the hospital. In 1876, another outbreak of eczema hospitalized several of the children. Contrasting this trend of epidemic outbreaks, a number of illnesses account for the increase in the patient population associated with the House of Providence in 1879.

\section{Professions}

From 1858 to $1879,18 \%$ of the male patients reported their occupation as laborer, $13 \%$ were farmers, $8 \%$ were sailors, and $5 \%$ were miners. While the variety of professions recorded for the male patients was numerous, (baker, clerk, blacksmith, bishop, doctor, lawyer, and gardener to name only a few), laborer, farmer, miner, and sailor were the most prominently represented professions at the hospital. Thus, for the most part, adult male patients were engaged in manual labor and were composed in part of a transient population of miners and sailors and the more permanently established urban and rural community. Likewise, during the 1850 s at the Commercial Hospital is Cincinnati, $46.8 \%$ of the male patients were unskilled laborers, only $3.5 \%$ were white-collar workers. 43

The miners were a phenomenon of the mid-1860s. In $1865,44 \%$ of the male patients received at St. Joseph gave their profession as 
miner. By 1867 , that trend changed radically with only $5 \%$ of the male patient population listed as miner. Ten years later, none of the male patients admitted to the hospital gave their profession as miner.

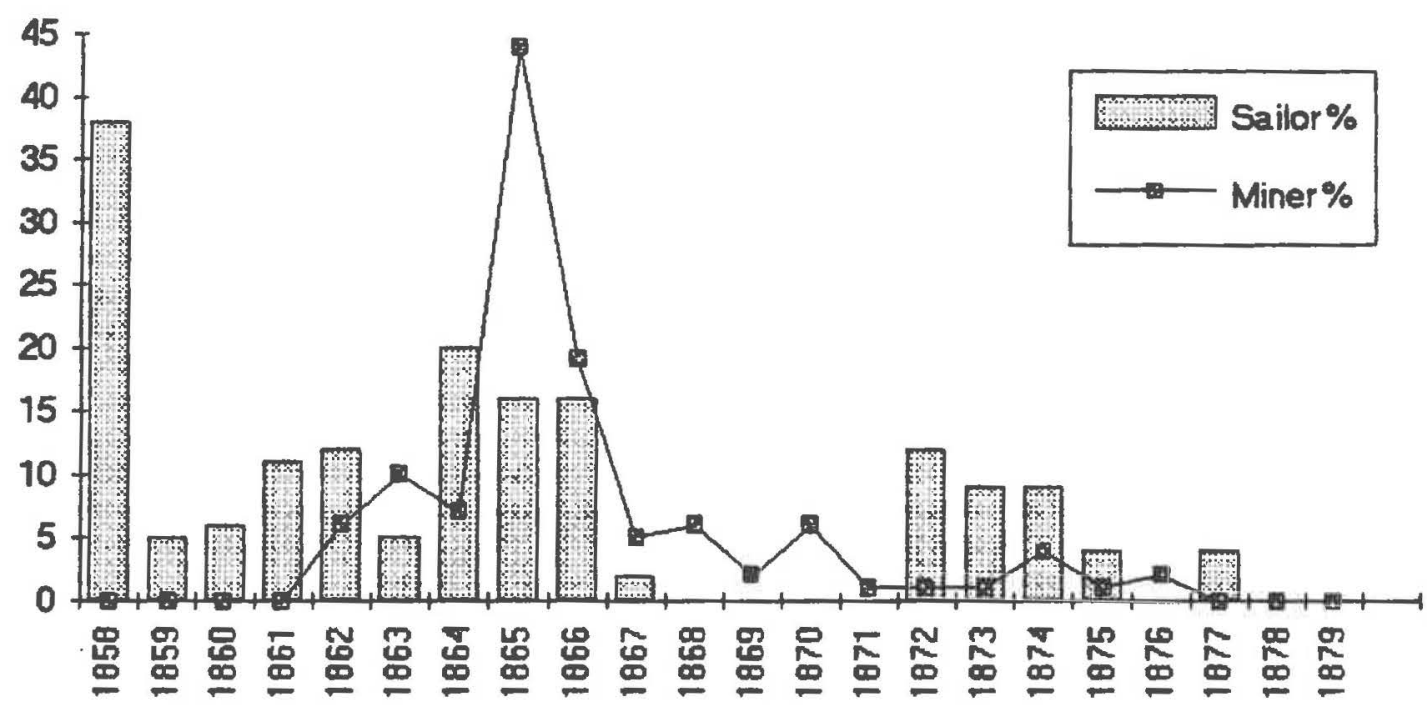

Figure 40. Percentage of male patients listed as sailor and miner.

Sailors were another transitory group that benefited from the hospital care provided by the sisters. Yet, they too, displayed a falling-away trend during the 1870s.

Parmers and laborers were another story. Laborers maintained a fairly consistent use of the facilities offered by the sisters. During the late $1850 \mathrm{~s}, 26 \%$ of the males admitted to the hospital reported their occupation as laborer. During the decade of the 1870s, $18 \%$ reported as such. Parmers were also consistently represented as patients at St. Joseph Hospital. During the 1860 s they represented $15 \%$ of the male patients while in the 1870 s that number fell only slightly to $13 \%$. 
It is not possible to assess the range or type of work that the professional category of laborer entailed. Undoubtedly, some were urban workers while others were agricultural laborers. Some came to the hospital for treatment, others came there to die.

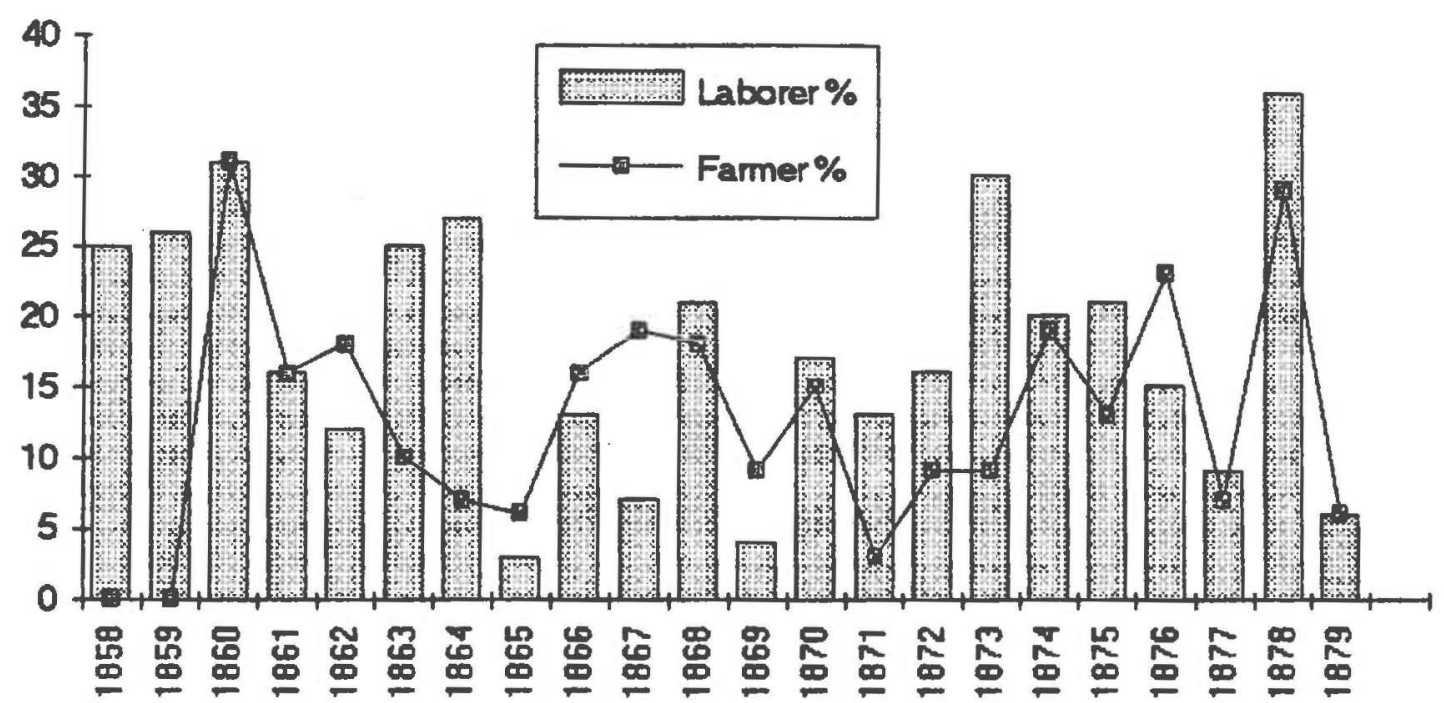

Figure 41. Percentage of male patients listed as laborer and farmer.

Sailors and miners were a transient population with no other social resources available in the immediate vicinity to rely on. This was probably the case with some of the laborers, but not all. The hospital served the community at large as the range of other professions listed in the patient register clearly indicates. Parmers, a stable population in the area, sought the care of the sisters despite the stigma associated with hospitals of the era. Need overcame the fear of stigmatization. The population of Oregon and Washington during the 1860 s and 1870 s held a majority of males, thus it is not surprising to see this imbalance reflected in the patient base at the hospital. But the predominance of the adult males 
as patients also reflected attitudes and expectations of the era. It was more acceptable for males, especially those lacking in personal support institutions such as family or kinship ties, to utilize hospital facilities. Wherever personal resources existed, they were the initial recourse of individuals during times of sickness. From the patient perspective, St. Joseph Hospital helped to soften the stigma of hospitalization by charging a modest fee. Adult women generally had support institutions available and relied on in-home help until such time as they perceived the need for professional care. The young ladies of the boarding school and the orphanage children were a special case. The hospital and the care provided by the sisters was their primary defense against illness.

St. Joseph Hospital began its existence as part of the Sisters of Providence missionary activities and was dedicated to helping the poor and sick. It was established as an institution more like an almshouse than a place of professional medical care. By the mid1860 s this situation changed. Both the physical institution and the attitudes of the sisters shifted toward health care professionalization with the involvement of trained medical personnel, the expansion of the hospital, the establishment of a pharmacy and the recording of disease information. While the sisters still maintained part of their missionary outlook, it diminished as a primary force at the hospital and was replaced by the need to provide better and more professional health care in the community. 
CHAPTER VIII

PERSPECTIVES, RECOLLECTIONS, AND REMEMBRANCES

Few immigrants to the Pacific Northwest expressed dispassionate attitudes toward their new homes, as most seemed pleased by their new surroundings. Either they subconsciously decided to adjust their attitudes to the conditions in which they found themselves, or they actually found their new environment more healthy or pleasant than their former residence. U1timately, the argument is a subjective one, at best difficult to substantiate. However, pioneers' perceptions of their new conditions reflected their observations and expectations and as such deserve consideration.

As one might expect to find in frontier regions, the Pacific Northwest had a small population per square mile ratio and no large urban areas. By comparison, the states which contributed the most immigrants to Oregon were densely populated. The Oregon Donation Land Act of 1850 contributed significantly to the settlement pattern immigrants established. With either a full section or half section home site, the population was widely distributed.1

${ }^{1}$ Bowen, The Willamette Valley, p. 25. Table 3: Oregon Population by Place of Origin, 1850. 
TABLE III

POPULATION PER SQUARE MILE OF SELECTED REgIONS

$\begin{array}{llll}\begin{array}{l}\text { Pop. per Square } \\ \text { Mile }\end{array} & 1850 & 1860 & 1870 \\ \text { Illinois } & 15.37 & 30.9 & 45.84 \\ \text { Indiana } & 29.24 & 39.94 & 49.71 \\ \text { Kentucky } & 26.07 & 30.94 & 35.33 \\ \text { Missouri } & 10.44 & 18.09 & 26.34 \\ \text { Oregon } & 0.05 & 0.55 & 0.95 \\ \text { Washington } & 0.00 & 0.06 & 0.34 \\ \text { USA } & 7.78 & 10.3 & 10.7\end{array}$

Source: Ninth Census, Volume I, Table XX: Areas, Families, and Dwellings in 1870 , p. 595.

Large homesteads tended to isolate families from each other which helped contain contagious disease. It also necessitated independent water supplies, which reduced the spread of water-born diseases. However, despite these isolating tendencies, rural families usually brought disease to each other. Because of cultural expectations, many women felt as Mary Elizabeth Munkers Estes did: "If there was sickness anywhere, I was glad to help them out. In fact, whenever there was a birth, a death, or sickness, you could usually count on finding me there, for $I$ was considered a good nurse."2 Pioneer Mary Robinson Gilkey noted, "In those days they knew nothing of contagious diseases and when a child had diphtheria all of the neighbors would come with their children to the

${ }^{2}$ Lockley, Conversations with Pioneer Women, p. 115. 
house to visit. The result was that within a few days or weeks there would be many funerals." 3

\section{RESIDENT OBSERVATIONS AND OPINION}

\section{Some Mixed Reviews}

In 1858, Oregonian Charles Stevens provided an enthusiastic impression of the healthful Pacific Northwest climate: "I tell you, it makes people young by coming here, and I have heard it said that people live to such an age, that moss will grow all over them."4 Stevens further asserted he had seen but one natural death resulting from "intemperate habits" and that women who, prior to migration, had long ceased to bear children, resumed the activity with vigor. 5

In contrast to Stevens' enthusiastic reports, a resident of Prench Prairie wrote: "this summer proves to be more sickly than any other yet known in Oregon." 6 The language chosen to express this sentiment is troublesome. Does this statement imply that relatively healthy conditions existed in prior summers or that most summers were sickly but this one was especially so? Given the hope

${ }^{3}$ Lockley, Conversations with Pioneer Women, p. 178.

${ }^{4}$ E. Ruth Rockwood, Ed. "Letters of Charles Stevens." Oregon Historical Quarterly 38 (June 1937): 164-192.

${ }^{5}$ Rockwood, "Letters of Charles Stevens." Oregon Historical Quarterly: 164-192.

${ }^{6}$ The Oregon Historical Society. MSS 620 Letters of Andrew Bauer 1810 - 1880 . 
of health benefits through migration, the first interpretation seems the most likely. Yet clearly, some residents expressed their belief in the increased incidence of disease in the expanding region. 7

In 1851, Oregon pioneer David Newsom, along with his wife Mary and their six children, left Sangamon County, Illinois on the overland trail to Oregon. Newsom wrote extensively to those back home about his observations and opinions of his new home land. He came with a firm belief that he would find the new land and people to his liking, and generally his hopes were self-fulfilled.

We believe that the indomitable energy that has induced the enterprise to Oregon, will be certain to make successful and valuable citizens, when such reach there. Those who have left us tell but one story; they are pleased with Oregon; they like the country; they make money at farming or other employments; they regret not their journey; they are doing well, enjoying health and all other blessings which should make them happy. ${ }^{8}$

Newsom repeatedly mentioned the generally superior health conditions he believed existed in oregon. Shortly after settling in Oregon in August 1852 he wrote to the editor of the Dlinois Journal:

The weather has been very warm and seasonable, and health remarkably good. There is no quaking and dreading the ague season here! Rob't Alexander-formerly of Richland...assured me a few days ago, that he had just come off of a two week's tramp; and had particularly examined into the health of the people...in

${ }^{7}$ The Oregon Historical Society. MSS 620 Letters of Andrew Bauer 1810 - 1880.

${ }^{8}$ David Newsom: The Western Observer 1805-1882. (Oregon Historical Society. Portland, OR, 1972), p. 13. 
Oregon, and that he did not find or see one sick person! 9

While Newsom was an enthusiastic advocate of Oregon and the health benefits to be found there, he also noted that "there is much sickness on the rivers" while the interior lands were generally considered healthy. 10

\section{The Trials of the Overland Trail}

The dangers associated with the overland journey were, for Newsom, the most troubling aspect of migration to Oregon. He consistently and clearly warned those back home of the dangers of the trail and the pitfalls of the new lands.

Oregon costs dearly in an overland trip to it...old persons or invalids should stay in the States. Oregon is a good country, but dearly bought in an overland trip to it..To see the widows and orphans and widowers arriving, worn down, sun-burnt, out of supplies; -many of them sick; and to hear them tell of horrors upon the road, and of the sufferings of those behind...I never would advise any friend to bring his family and his all, on that dreary and forlorn trip, the very memory of which causes me to shudder.11

Almost seven years after his overland trail experiences, Newsom still presented a negative view of his journey. In February of 1858, he remembered the hardships of relocating via the over land route, and proclaimed that "No earthly inducement would cause me to take the

\footnotetext{
${ }^{9}$ Newsom, Western Observer, p. 43.

${ }^{10}$ Newsom, Western Observer, pp. 30, 39.

${ }^{11}$ Newsom, Western Observer, p. 45.
} 
'pleasure trip' again."12 Newsom found what he wanted and desired in Oregon. He was convinced that in Oregon, "As to health, our country is blessed with that, to a great degree...0regon in her soil, climate, timber, grass, health, water, navigation and local positions, is unsurpassed by any portion of North America." 13

\section{MEDICAL OPINION, PROPESSIONAL AND OTHERWISE}

\section{Observations from Community Members}

Pioneer Phoebe Goodell Judson remembered that professional medical help was often not easily summoned, thus settlers relied on each other to help in times of need. However, recalled Judson, since "This climate being so healthy, I am happy to say, there was little need of a physician, except in cases of accident or increases of population."14

Some doctors of the era would undoubtedly second Judson's views. Yet physicians and their observations reflected only the individual's perception. Despite this drawback, doctors were members of a community that others actively sought out with their health concerns. Thus, physicians formed opinions on the general health conditions that addressed their concerns and those of their patients.

12 Newsom, Western Observer, p. 73.

${ }^{13}$ Newsom, Western Observer, p. 73.

${ }^{14}$ Phoebe Goodell Judson. A Pioneer's Search for an Ideal Home. (Lincoln and London: University of Nebraska Press, 1984), p. 265. 
Across the board, physicians' opinions could not be considered representative of the collective views of the population. Despite the presence of professional medical help, many families simply could not afford to rely on a doctor. Widely dispersed in a rural environment that lacked modern transportation, the great majority of these settlers were effectively cut off from a physician's services. It was not the direct fees so much as the indirect costs involved in transportation and lost labor or wages that forced rural folks to count on their own methods. 15

Some doctors found the Pacific Northwest a difficult place to establish a practice. One physician who had formerly resided and practiced medicine in Oregon during the $1850 \mathrm{~s}$ recalled his time there somewhat sarcastically. Regarding his current practice he wrote: "We sometimes get tired in New York at having too much to do. We frequently got tired in Oregon at having nothing to do."16 Dr. Anson Dart, Superintendent of Indian Affairs in the Oregon Territory during the 1850 s, lent support to the position that doctors were underemployed in Oregon. In a letter printed in the Cleveland Herald and reprinted in the Oregon Statesman, Dart wrote:

The prospects for the farmers in Oregon are better than in any other portion of the country with which I am acquainted. Labor of every kind command high prices.

${ }^{15}$ Paul Starr. The Social Transformation of American Medicine. (New York: Basic Books, Inc., Publishers, 1982), p. 66.

${ }^{16}$ The Oregon Historical Society. MSS 1037 Letters of Alden H. Steele, 1823 - 1902. Letter dated 19 June 1854 from Dr. Thomas Nelson of New York. 
There are nevertheless, many that are idle in the towns, such as doctors, lawyers, clerks, speculators and gamblers - talented lawyers, however are doing well. 17

\section{Disease Reports and the Community}

During the 1860s, the frequency of sickness and disease articles in local papers such as the Oregon Statesman suggested an increase in the number of serious outbreaks of many diseases. Headlines such as "Sickness and Death in Portland Children" and "Typhoid, pneumonia affect children in the Dalles"18 regularly appeared in local print. Evidence provided by these notices suggest that children of the region were more at risk and vulnerable to outbreaks of infectious diseases.

In 1865, Dr. Robert Glisan published an article on his observation of the climate and diseases of Oregon during his sojourn through the area during the 1860s. His comments about diseases, while lacking definitive proof, are somewhat enlightening due to the nature of his professional experience and training. Overall, Glisan concluded that "it must be admitted that the climate is as healthy as any other." 19 Glisan's statement presents a problematic interpretation. Does the author wish to suggest that there is just as

17 Dr. Anson Dart. "Letter to the Editor.", Oregon Statesman, 3 July 1852 2:7.

18 Anonymous. "Sickness and Death in Portland children.", Oregon Statesman, 14 July 1862, 3:2. Anonymous. "Typhoid, pneumoniá affect children in the Dalles.", Oregon Statesman, 1 Pebruary 1864, $2: 4$.

${ }^{19}$ Robert Glisan, "Climate and Diseases of Oregon." American Journal of Medical Sciences. 49 (Jan 1865): 78. 
much disease as in other locations? Glisan's further comments suggested otherwise; he seemed convinced of beneficial conditions in Oregon, even though he noted that the diseases which plague other regions of the U.S. were also seen in Oregon. 20

Even though local physicians in Portland described the prevalence of malarial fevers, Glisan dismissed this idea. In his estimation, Oregon's fevers were not comparable with other regions of the United States. However, he does mention the outbreaks of epidemic diseases during the early 1860s which extensively affected children. 21

With regard to the health practices of residents, Glisan noted that many of the same medical technologies practiced in other regions were known and followed in oregon. For example, homeopathy was well represented in Portland while in "unenlightened sections," water cures and herbal practices prevailed. He also reported that bloodletting and calomel were still regularly utilized by "physicians in the interior." 22

Glisan's article demonstrates and documents some of the health practices and beliefs about oregon during the 1860s. Clearly the residents of Oregon, via their medical practitioners, were aware of

${ }^{20}$ Glisan, "Climate and Diseases of Oregon." American Journal of Medical Sciences.: 77-78.

$21_{\text {Glisan, "Climate and Diseases of Oregon." American Journal of }}$ Medical Sciences.: 78.

${ }^{22}$ Glisan, "Climate and Diseases of Oregon." American Journal of Medical Sciences.: $81-82$. 
and practiced a variety of health techniques. While the diseases of contemporary life were present in Oregon, the environment was perceived to be as "healthy" as any other, and superior with respect to the "miasmatic" fevers suffered in other regions.

\section{LOCAL OBSERVATIONS}

The assistant marshal who recorded his remarks on the mortality schedule of Clatsop County during the Ninth Census, perhaps echoed a generally held belief of Oregonians of the era. He wrote, "Clatsop county is considered the healthyest (sic) place on the Pacific Coast." 23 The mortality schedule included only 5 entries, which supported his assessment of the general well-being of the residents of the county.

When they bothered to comment at all, census takers found more good to praise than problems to complain about with respect to Oregon's health environment. In 1880, enumerator W.D. White recorded his impression of the healthy nature of the climate in Clackamas County. "Moreover, I found the health of the inhabitants to be good with some deaths from diseases of any kind from attending to the ordinary duties of life."24

23 U.S. Bureau of the Census. Ninth U.S. Census. Schedule 2 Persons who Died during the Year ending 1st June, 1870 in Clatsop County, Oregon. Microfilm. Salem, OR: Oregon State Archives.

${ }^{24}$ U.S. Bureau of the Census. Tenth U.S. Census. Schedule 5 Persons who Died during the Year ending 31st May, 1880 in Clackamas County, Oregon. Microfilm. Salem, OR: Oregon State Archives. 
Census takers also noted disease patterns and problem locales that appeared to accommodate ill health. Assistant marshal H. B. Parker noted in his appraisal of Columbia County that malaria was known to exist in the region. He wrote, "Columbia is a healthy county with the exception of the vicinity of Sauvies Island where the Ague and measles prevail to a considerable extent." While only 3 deaths are recorded for Columbia County in 1870, none were attributed to either measles or malaria. 25 Han. J. Cole, enumerator of Douglas County in 1880 , recorded 16 deaths in his district during the 10th U.S. Census. His comments described the patterns of infections he observed. Cole wrote:

\begin{abstract}
Diphtheria seems to prevail in this valley as an endemic rather than epidemic occurring in certain locations only. Typhoid fever cases occur rather frequently and at any season of the year, cases generally amiable to treatment. Acute Rheumatism rheumatism (sic) is of frequent occurrence - cases generally mild seldom resulting fatally. 26
\end{abstract}

Census takers also noted where health problems could not be attributed to Oregon's climate. Regarding the death of Benjamin Sloan, age 52, Josephine County enumerator A.H. Carson noted, "This was a case of long standing. Disease contracted in the state of

25 U.S. Bureau of the Census. Ninth U.S. Census. Schedule 2 Persons who Died during the Year ending 1st June, 1870 in Columbia County, Oregon. Microfilm. Salem, OR: Oregon State Archives.

${ }^{26}$ U.S. Bureau of the Census. Tenth U.S. Census. Schedule 5 Persons who Died during the Year ending 31st May, 1880 in Douglas County, Oregon. Microfilm. Salem; OR: Oregon State Archives. 
Missouri some 25 years ago." 27 It seemed that when the health seekers flocked to Oregon, they brought their problems with them. Thus, with contagious diseases, settlers passed their health problems on to the general population and the next generation. One could only run so far from the realities of sickness and death.

Perhaps those who found Oregon's climatic and health conditions problematic simply left the area without leaving evidence of their disappointments and disillusionment. Most who wrote on the subject generally found conditions to their liking. Some like David Newsom attempted to be evenhanded about their perceptions. Generally, he found most of Oregon to his liking. While his letters home noted the minor catastrophes of flooding or crop loss, by far his positive observations of pleasant valleys and mild climates dominated his correspondence. 28 In August, 1853 Newsom observed that:

Oregon has been over rated and under rated very much; but the truth lies between both statements...Yet I rejoice that I and mine are here and well and doing well. If you could see your old friend and his family, all looking ten years younger, with light step, rosy cheeks, fat as pigs, in a healthy, mild climate here, and all things around them flourishing:...you could not fail to be glad for me and mine, and say I did right to leave Illinois and move here. 29

27 U.S. Bureau of the Census. Tenth U.S. Census. Schedule 5 Persons who Died during the Year ending 31 st May, 1880 in Josephine County, Oregon. Microfilm. Salem, OR: Oregon State Archives.

${ }^{28}$ Newsom, Western Observer, pp. $42,47$.

${ }^{29}$ Newsom, Western Observer, p. 53. 
CHAPTER IX

\section{CONCLUSION}

Pacific Northwesterners came to secure a better life, both economically and esthetically. They established communities and societies which, in most cases, persisted leaving one to conclude that the settlers achieved at least part of their objectives. Statistics suggest that the population as a whole improved its general mortality by relocating. However, the immigrants still faced health issues that individuals alone could not address.

The characteristics of the Pacific Northwest's population in the 1860 s and 1870 s showed that the settlers were mostly male and largely youthful. While adult males were overly represented in terms of population, the situation differed from some of the other frontier regions in terms of other population groups which more closely resembled (proportionally) the national trends. The method used to establish settlement in Oregon, in large part brought family settlement, not just single adult males to the region. Oregon's mortality rates in the 1860 s and 1870 s compared favorably with the national averages. With the exception of females of childbearing ages, age group mortality rates were generally below that of the nation. Many aspects of the new environment, including settlement patterns and the age structure of the population, accounted for the lowerthan-average death rates. 
At St. Joseph Hospital, philosophical and procedural changes were implemented that initiated a change from the almshouse mentality toward the establishment of professional health care. The role of community service the sisters pursued, in no small way, promoted the development and expansion of their hospital. The desire to better serve the patients' needs, along with local competition for patients, encouraged the precedence of medical care over missionary work which, while still fundamental to the sisters, slowly receded as the primary impulse at the hospital. The patient base in general reflected the demographics of the region. Adult males made up the majority of patients treated at the hospital. For some patients, the hospital represented their only resource during times of illness. For others, the hospital was a last resort, a place to seek aid beyond the men's and women's abilities to care for themselves. Thus, in the early days, St. Joseph Hospital was a place where some people came to make their peace with God and die. The mission itself supplied a younger population of patients who were predominately female. For these patients, the sisters represented their primary social recourse for health problems, supplanting other institutions, especially the family. Thus, the hospital drew patients from the community-at-large in both transient and the more permanently established populations and it answered the needs of the mission itself by providing care for the orphans and school children who were under the guardianship of the sisters. To address these health needs, the sisters expanded and professionalized hospital operations. 
The new settlers to the Pacific Northwest did establish a settlement pattern that encouraged better health conditions, but they were still left with basic conditions that often worked against them. In the name of community support, they often inadvertently contributed to the spread of contagious diseases. Yet many perceived they had found through relocation, health conditions that were vastly superior to those they had abandoned. While malaria was known to exist in the Pacific Northwest, it afflicted the population in the region on a significantly reduced scale. Many professed to believe that, in terms of health, Oregon's climate was beneficial to those who lived there. On the other hand, as communities developed, they were faced with the same problem other more densely populated regions confronted; namely the outbreak of epidemic disease. Thus, many of those who migrated to secure better health conditions achieved their goal. On the other hand, they still existed within the limitations of contemporary knowledge which often worked against their purpose of securing a disease-free environment. 


\section{REFERENCES}

PRIMARY SOURCES

\section{Unpublished Material}

Cliff, Harry R. "Medical Economics Lecture" 13 May 1936. Notes of lecture at Oregon Health Sciences University.

Portland, OR. The Oregon Historical Society. MSS 620 Letters of Andrew Bauer 1810 - 1880 .

Portland, OR. The Oregon Historical Society. MSS 742 Handbook of Remedies of John Kennedy Fristow, circa 1814.

Portland, OR. The Oregon Historical Society. MSS 822 Letters, bills and receipts of G.S. Cozad.

Portland, Or. The Oregon Historical Society. MSS 830 Notebook of George Bolter, 1893.

Portland, OR. The Oregon Historical Society. MSS 1116 Account book of Justin Millard 1853 - 1855.

Portland, OR. The Oregon Historical Society. MSS 1037 Letters of Alden H. Steele, 1823 - 1902.

Portland, OR. Washington County Historical Society. MSS 194 Linklater Collection.

Seattle, WA. Sisters of Providence Archives. MSS 22

"Act of Incorporation, 1959"

"Boarders' Accounts", Providence of the Holy Angels 1857-1889

"Chronicles of the Provincial House"

Seattle, WA. Sisters of Providence Archives. MSS 23

"Patient Register, St. Joseph Hospital"

"Register of Outpatients"

"Chronicles of St. Joseph Hospital," Dorothy Lenz, tr. 
Published material

Congar, Rosa Cadman. The Educator: Cause and Cure of All Diseases. 2nd Edition. Chicago: Educator Publishing Company, 1888.

Buchan, William. A Treatise on the Prevention and Cure of Diseases by Regimen and Simple Medicines. Cincinnati: J.A. James Publisher, 1841.

Flint, Timothy. The History and Geography of the Mississippi Valley. 2 volumes, 2nd edition. Cincinnati: E.H. Flint and L.R. Lincoln; 1832.

Glisan, R. "Climate and Diseases of Oregon." American Journal of Medical Sciences. 49 (Jan 1865): 73-82.

Gunn, John C. Gunn's New Family Physician: Home Book of Health. Cincinnati: Moore, Wilstach and Baldwin, 1858, 1864.

Jackson, Ronald Vern, Wylma Winmill, and Shirley P. Zachrison, Ed. Oregon 1850 Mortality Schedule. Bountiful, UT: Accelerated Indexing Systems, 1980.

Jackson, Ronald Vern, Wylma Winmill, and Shirley P. Zachrison, Ed. Oregon 1860 Mortality Schedule. Bountiful, UT: Accelerated Indexing Systems, 1980.

Jayne, David. Jayne's Medical Almanac and Guide to Health for Washington, Oregon, California, Utah and Sandwich Islands for the year 1859. Philadelphia: James S. McCalla, Printer, 1859.

Judson, Phoebe G. A Pioneer's Search for an Ideal Home. Lincoln: University of Nebraska Press, 1984.

Newsom, David. David Newsom: The Western Observer 1805-1882. Oregon Historical Society. Portland, OR, 1972.

Ralph, Joseph. A Domestic Guide to Medicine. New York: General Office of the Genuine Improved Hygeian Pills, 1834.

Peck, John M. Mid-American Frontier: A Guide for Bmigrants. New York: Arno Press, 1831.

Porter, Mildred, compiler. United States Census of the Washington Territory 1860. Clark County. Vancouver: Clark County Genealogical Society, 1982.

- United States Census of the Washington Territory 1870, Clark County. Vancouver: Clark County Genealogical Society, 1982. 
Rockwood, E. Ruth, Ed. "Letters of Charles Stevens." Oregon Historical Quarterly 38 (June 1937): 164-192.

Thwaites, Ruben G. editor. Early Western Travels 1748-1846.

Cleveland: Arthur H. Clark Co., 1904.

Vol. IV Cuming, Fortescue "Sketches of a Tour to the Western Country"

Vol. V Bradbury, John "Travels in the Interior of America in the years $1809,1810,1811^{\prime \prime}$

Vol. IX Flint, James "Letters from America"

Vol. XXII Part I of Maximilian, Price of Wied's "Travels in the Interior of North America 1832-1834"

Vol. XXVII Part II of "Flagg's Far West 1836-67"

Warren, Ira and A. E. Small. The Household Physician; for the use of Families, Planters, Seamen and Travelers. Boston: Ira Bradley and Company, 1878.

Williams, John. Last Legacy and Useful Pamily Guide. Boston: Printed for the Publishers, 1841.

Medical and Surgical Directory of the United States. Detroit, MI: R.L. Polk and Company, Publishers, 1886.

\section{GOVERNMENT RECORDS AND PUBLICATIONS}

Kennedy, Jos. C.G. Preliminary Report on 8th Census 1860.

Washington, D.C.: Government Printing Office, 1862.

U.S. Bureau of the Census. Ninth Census. Washington, D.C.: Government Printing Office, 1872)

-- Ninth U.S. Census. Schedule 2 - Persons who Died during the Year ending 1st June, 1870 in Clatsop County, Oregon. Microfilm. Salem, OR: Oregon State Archives.

-- --- Ninth U.S. Census. Schedule 2 - Persons who Died during the Year ending 1st June, 1870 in Columbia County, Oregon. Microfilm. Salem, OR: Oregon State Archives.

- Tenth U.S. Census. Schedule 5 - Persons who Died during the Year ending 31st May, 1880 in Clackamas County, Oregon. Microfilm. Salem, OR: Oregon State Archives.

- - Tenth U.S. Census. Schedule 5 - Persons who Died during the Year ending 31st May, 1880 in Douglas County, Oregon. Microfilm. Salem, OR: Oregon State Archives. 
U.S. Bureau of the Census. Tenth U.S. Census. Schedule 5 - Persons who Died during the Year ending 31st May, 1880 in Josephine County, Oregon. Microfilm. Salem, OR: Oregon State Archives.

- - Statistical Abstract of the United States: 1990. 110th edition. Washington, D.C: Government Printing office, 1990.

- Benevolent Institutions 1910. Washington D.C.: Government Printing Office, 1913.

\section{SECONDARY SOURCES}

The American Medical Association, Charles Clayman Ed. Encyclopedia of Medicine. New York: Random House, 1989.

Bledstein, Burton, J. The Culture of Professionalism. New York: W.W. Norton \& Company, Inc., 1976.

Bowen, William A. The Willamette Valley. Seattle: University of Washington Press, 1978.

Brougher, John. "Pioneer Medicine in Clarke County, Washington." Northwest Medicine 57 (June 1958): 739-746.

Camp, John. Magic, Myth and Medicine. New York: Taplinger Publishing Company, 1974.

Cassedy, James H. American Medicine and Statistical Thinking, 1800 1860. Cambridge: Harvard University Press, 1984.

Dodds, Gordon B. The American Northwest. Arlington Heights: The Forum Press, Inc., 1986.

Duffy, John. The Healers. New York: McGraw-Hill Book Company, 1976.

Faragher, John M. Women and Men on the Overland Trail. New Haven and London: Yale University Press, 1979.

Haller Jr., John S. American Medicine in Transition, 1840 - 1910. Urbana: University of Illinois Press, 1981.

Hollingsworth, T.H. Historical Demography. London: Sources of History Limited, 1969.

Jeffrey, Julie R. Frontier Women. New York: Hill and Wang, 1979.

Jones, Billy M. Health-Seekers in the Southwest, 1817-1900. Norman, OK: University of Oklahoma Press, 1967. 
Kett, Joseph. The Formation of the American Medical Profession. New Haven: Yale University Press, 1968.

Keyfitz, Nathan and Wilhelm Plieger. Population: Facts and Methods of Demography. San Francisco: W.H. Freeman and Company, 1971.

Larsell, Olof. The Doctor in Oregon. Portland, OR: Binfords and Mort, 1947.

-_- "History of Medical Journals in the Pacific Northwest." Oregon Historical Quarterly 47 (March 1946): 3-15.

Leavitt, Judith Walzer and Ronald L. Numbers, Ed. Sickness and Health in America. 2nd Edition. Madison, WI: The University of Wisconsin Press, 1985.

Lockley, Fred. "Recollections of Benj. Franklin Bonney." Oregon Historical Quarterly 24 March 1923: 54.

- - Conversations with Pioneer Women. Eugene: Rainy Day Press, 1981.

McArthur, Harriet Nesmith. "Recollections of the Rickreall." Oregon Historical Quarterly 30 (December 1929): 362-383.

McCrosson, Mary. The Bell and the River. Palo Alto: Pacific Books, Publishers, 1957.

McKeown, Thomas. The Modern Rise of Population. New York: Academic Press, 1976.

Morrow, Mary Claver. "Providence of the Holy Angels Vancouver, WA 1856 - 1874" Unpublished paper in MSS 22 Seattle: Sisters of Providence Archives, (no date).

Moynihan, Ruth Barnes. Rebel for Rights. Abigail Scott Duniway. New Haven: Yale University Press, 1983.

Pfeiffer, Carl J. The Art and Practice of Western Medicine in the Early Nineteenth Century. Jefferson: McFarland \& Company, Inc. Publishers, 1985.

Rawlings, Isaac D. The Rise and Fall of Disease in Illinois. 2 Vols. Springfield: State Dept. of Public Health, 1927.

Reverby, Susan and David Rosner, Ed. Health care in America. Philadelphia: Temple University Press, 1979.

Rosenberg, Charles E. The Cholera Years. Chicago: The University of Chicago Press, 1962, 1987. 
Rosenberg, Charles E. The Care of Strangers. New York: Basic Books, Inc., Publishers, 1987.

Rothstein, William G. American Physicians in the Nineteenth Century. Baltimore: The Johns Hopkins University Press, 1972.

Sanderson, Warren C. "Quantitative Aspects of Marriage, Fertility and Pamily Limitation in Nineteenth Century America: Another application of the Coale Specification." Demography 16 Aug 1979: 339-358.

Schoenberg, Wilfred P. A History of the Catholic Church in the Pacific Northwest 1743-1983. Washington, D.C.: The Pastoral Press, 1987.

Shafer, Henry B. The American Medical Profession 1783 to 1850. New York: AMS Press, 1968, 1936.

Starr, Paul. The Social Transformation of American Medicine. New York: Basic Books, Inc., Publishers, 1982.

Thomas, Bryn. An Archaeological Assessment of the St. James Mission Property. Cheney, WA: Eastern Washington University Reports in Archaeology and History, 1984.

Vachon, Marilu. "Providence Academy: Its Construction and Contribution" Unpublished paper in MSS 22 Seattle: Sisters of Providence Archives, 1974.

Vogel, Morris J. "The Transformation of the American Hospital, 1850 1920." in Health Care in America, pp. 105-116. Edited by Susan Reverby and David Rosner. Philadelphia: Temple University Press, 1979.

Waite, Frederick C. "Medical Education of Dr. Whitman." Oregon Historical Quarterly. 37 (September 1936): 192-216.

Warner, John Harley. "Power, Conflict and Identity in Mid-Nineteenth Century American Medicine: Therapeutic Change at the Commercial Hospital in Cincinnati" The Journal of American History. Vol. 73 No. 4 March 1987, 934-956.

Williams, W.M. Demographic Analysis. New York: Prederick A. Praeger, Publishers, 1968.

Young, James Harvey. "Patent Medicines and the Self-Help Syndrome." In Sickness and Health in America, pp. 71-80. Edited by Susan Reverby and David Rosner. Madison: The University of Wisconsin Press, 1985. 
A Brief Historical Sketch of The Academy. Vancouver: The Academy and Hidden Brick Company, 1977.

NEWSPAPERS

Oregon Statesman, Salem, OR.

Vancouver Chronicle Vancouver, WA.

Vancouver Independent Vancouver, WA.

Vancouver Register, Vancouver, WA.

Weekly Oregonian, Portland, OR. 